\title{
Regionalisation of nitrate leaching on pasture land in Southern Manitoba
}

By

Simratpal Singh

A Thesis submitted to the Faculty of Graduate Studies of

The University of Manitoba

in partial fulfillment of requirements for the degree of

Master of Science

Department of Civil Engineering

The University of Manitoba

Winnipeg, Manitoba

(C) Copyright 2017 by Simratpal Singh 


\begin{abstract}
Nitrogen is a key agricultural input which is considered to be crucial for crop growth, development, and yield. However, an excess application of anthropogenic nitrate in the form of fertilizers may result in the nitrate contamination of groundwater. A critical time in continental climates in Canada having long and cold winters is nitrate leaching during soil thawing since fast recharge fluxes may occur during that time. The objective of this research was to estimate leaching of nitrate upon the application of liquid hog manure on a pasture land in Southern Manitoba using physically based modeling and to further regionalise the point estimates of nitrate leaching fluxes at the field scale. Data for this research were taken from the Ph.D. study by Coppi (2012). During that study, the field site located in La Broquerie, Manitoba was divided into 6 types of plots namely - control-hayed, control-grazed, full-hayed, full-grazed, split-hayed, and split-grazed treatment plots. The control, full and split treatments plots represented no application of manure, one-time application in a year with full rate and two-times application in a year with half rates each time respectively. Haying and grazing were two types of forage harvesting treatments carried out on in the study site. Data on climate, soil texture, soil moisture, soil temperature, and nitrate concentrations in groundwater at 16 sensor stations (SS) during different manure application rates were observed for years 2008 and 2009 (Coppi, 2012). In this research, one-dimensional physically based modeling was applied using HYDRUS-1D to determine continuous recharge and nutrient leaching estimates from these data. The regionalisation of simulated leaching estimates was done using Cokriging which is a geostatistical interpolation approach. Results showed a good agreement of the simulated and observed soil moisture contents at 15, 45, 75 and $105 \mathrm{~cm}$ depths in the soil profile having RMSE between $0.7 \%$ and 5\%, NSE between 0.39 and 0.99 and ME nearly equal to zero. On an average,
\end{abstract}


the recharge was estimated as $156.5 \mathrm{~mm}$ and $253.5 \mathrm{~mm}$ for the years 2008 and 2009 respectively. It was observed that about $42 \mathrm{~mm}$ of recharge out of $150 \mathrm{~mm}$ (about 28\%), occurred during the snow-melt period of the year 2008 at SS-3. The difference in simulated and observed nitrate concentrations in groundwater was expressed in terms of RMSE between 0.023 and $5.12 \mathrm{mg}$ $\mathrm{NO}_{3}-\mathrm{N} \mathrm{L}^{-1}$, NSE between 0.66 and 0.96 and the ME between $-1.03 \mathrm{mg} \mathrm{NO}-\mathrm{N} \mathrm{L}^{-1}$ and $1.05 \mathrm{mg}$ $\mathrm{NO}_{3}-\mathrm{N} \mathrm{L}^{-1}$. The areas which posed a risk to nitrate contamination of groundwater were the bare earth areas (BEA). The observed and simulated results showed that the groundwater nitrate concentrations in BEAs of both control-grazed and full-grazed plots were consistently higher than $10 \mathrm{mg} \mathrm{NO}-\mathrm{N} \mathrm{L}^{-1}$. Overall, the cumulative nitrate leaching fluxes for control-hayed, fullhayed and control-grazed plots were below $2 \mathrm{~kg} \mathrm{NO}_{3}-\mathrm{N} \mathrm{ha}^{-1}$ for both years. However, for fullgrazed plots, the cumulative nitrate leaching flux was about $11 \mathrm{~kg} \mathrm{NO}_{3}-\mathrm{N} \mathrm{ha}^{-1}$ and $6 \mathrm{~kg} \mathrm{NO}_{3}-\mathrm{N}$ ha $^{-1}$ for 2008 and 2009 respectively. The cumulative leaching fluxes in BEAs were about 100 times larger than those in grassed areas. The non-accommodation of soil freezing and thawing processes in model simulations was one of the major limitations of this research since these processes are very important to evaluate solute redistribution, water balance, and snowmelt infiltration correctly in the frozen soils. Overall, HYDRUS-1D can be considered as a useful tool in quantifying the recharge and nitrate leaching estimates for pasture fields subjected to continental climates, and Cokriging can be considered as a reliable method for a study site where cross-correlations between variables are important to consider for carrying out interpolation. 


\section{Acknowledgements}

Foremost, I would like to express my sincere gratitude to my advisor Dr. Hartmut Holländer for the continuous support of my M.Sc. study and research, for his patience, motivation, enthusiasm, and immense knowledge. His guidance helped me in all the time of research and writing of this thesis. Without his incredible patience and timely wisdom and counsel, my thesis work would have been a frustrating and overwhelming pursuit.

In addition, I express appreciation to my advisory committee members: Dr. Masoud Asadzadeh and Dr. Graham Phipps for their encouragement, insightful comments, and hard questions. Furthermore, I would like to thank Dr. Luca Coppi who provided me the data of his work, without which this study was impossible. 
This thesis is dedicated to my parents who have taught me to be strong and hardworking and because of all their sacrifices and supports through my way.

There is no way to thank you enough! 


\section{Table of Contents}

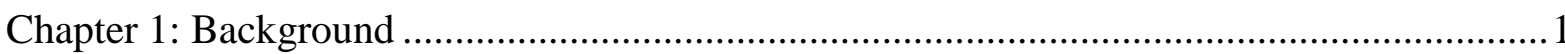

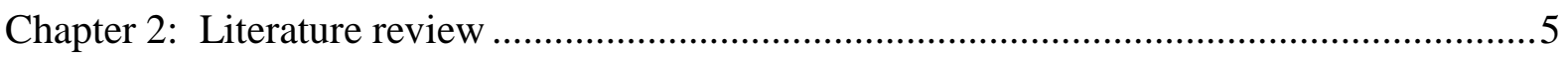

2.1 Nitrate in Canadian groundwater \& environmental implications ................................5

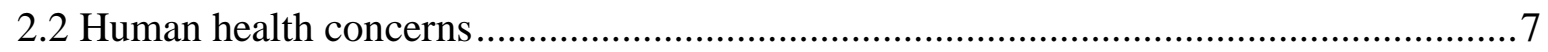

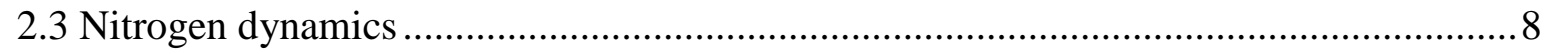

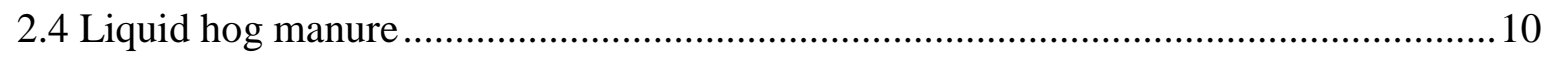

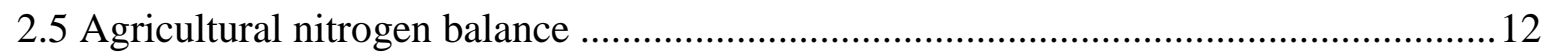

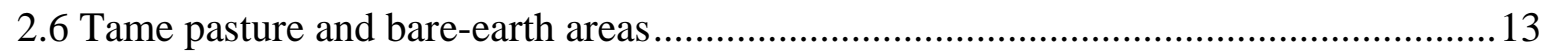

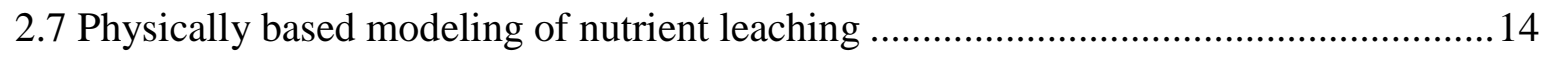

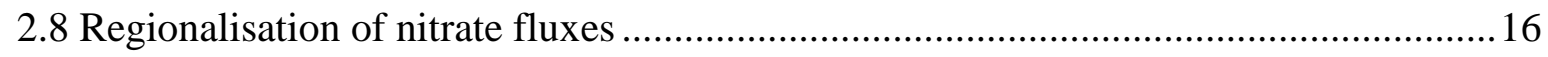

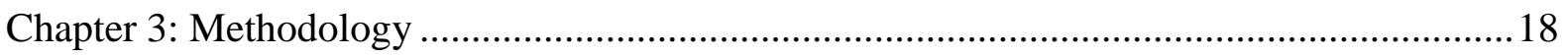

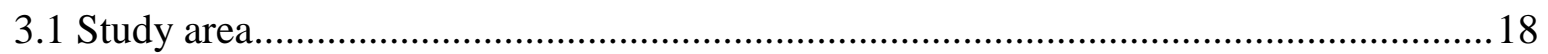

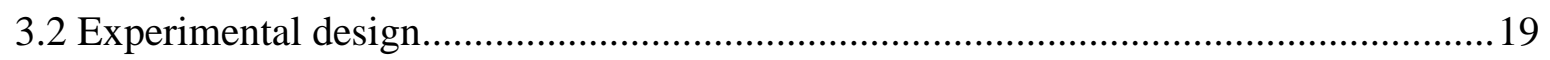

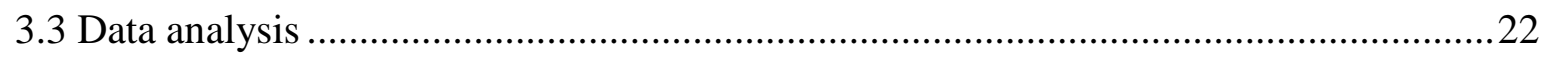

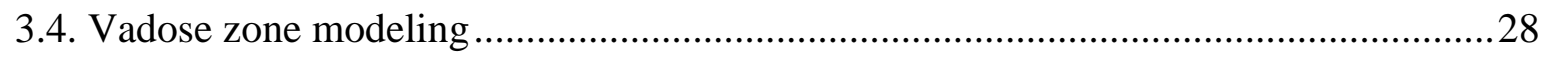

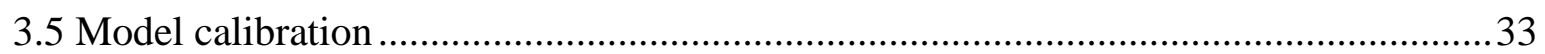

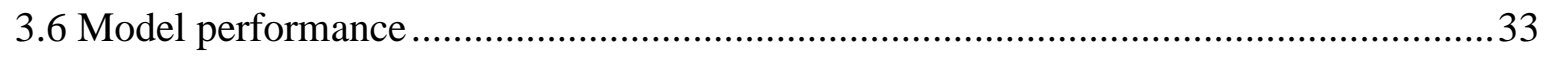

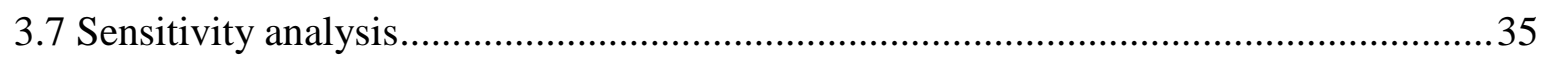

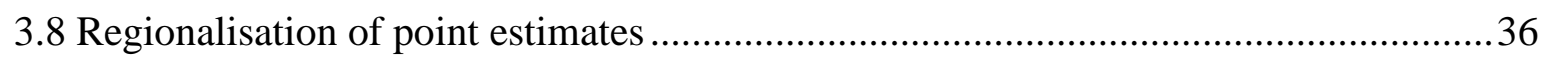

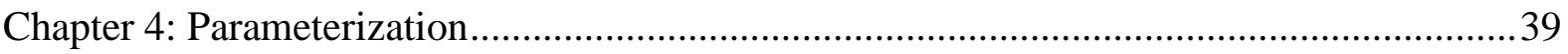




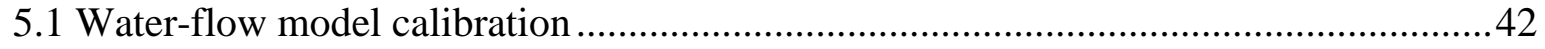

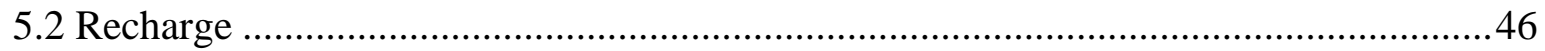

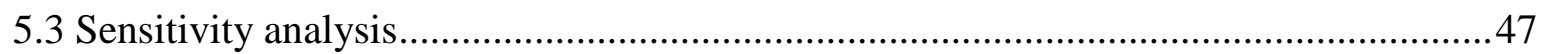

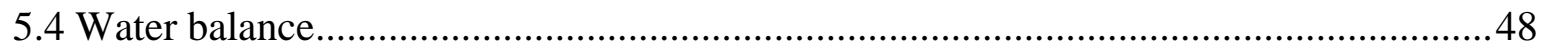

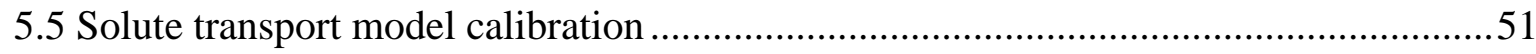

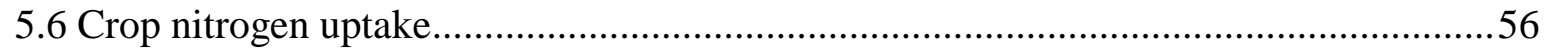

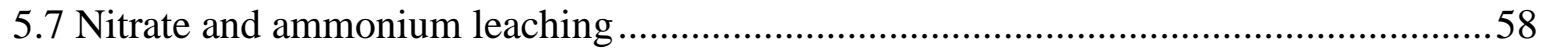

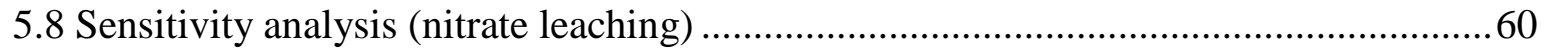

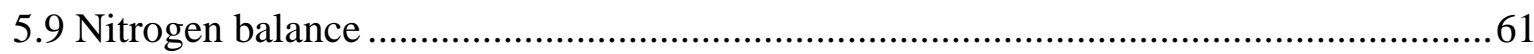

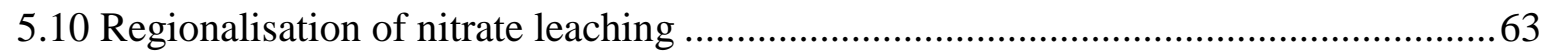

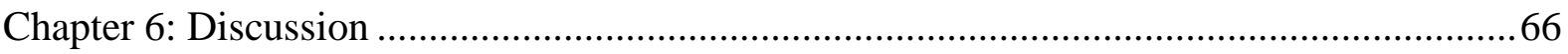

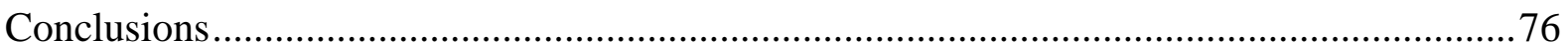

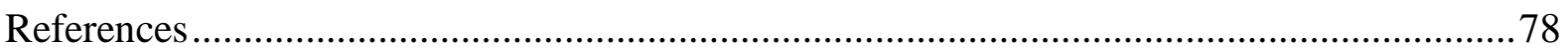

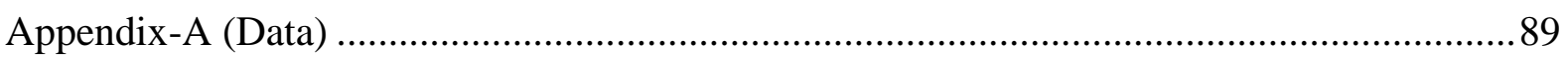

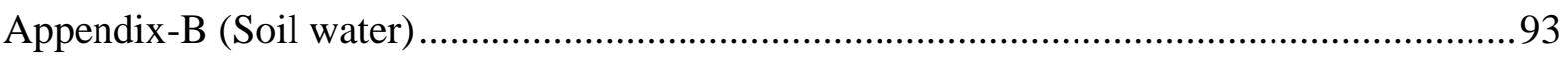

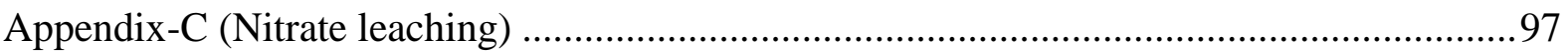




\section{List of figures}

Figure 1: Soil-N cycle showing complex and dynamic behaviour of nitrogen in soil with many transformations (solid black lines) and potential losses (dashed lines) .8

Figure 2: Location of the study site in Manitoba, Canada 20

Figure 3: Layout of the research site in La Broquerie, the total size of which is 40 ha, showing the division of site into slurry and forage utilization treatments .21

Figure 4: Daily mean observed air temperature and precipitation at Campbell Scientific weather station (Jan 2008 to Oct 2009). Data source (Coppi, 2012)

Figure 5: Depth to groundwater table from soil surface measured at SS-3 for the years 2007, 2008 and 2009. Elevation of monitoring wells was $303.52 \mathrm{~m}$ asl. (Data source: Coppi, 2012)

Figure 6: Observed soil moisture content at SS-3 (depth: $15 \mathrm{~cm}$ below soil surface). Data source (Coppi, 2012).

Figure 7: Observed nitrate groundwater concentrations at SS-1 to SS-4 and their average for the years (a) 2008 and (b) 2009 .25

Figure 8: Observed nitrate groundwater concentrations at SS-5 to SS-8 and their average for the years (a) 2008 and (b) 2009 .25

Figure 9: Observed nitrate groundwater concentrations at SS-10, SS-12, SS-14 \& SS-16 for the years (a) 2008 and (b) 2009

Figure 10: Observed nitrate groundwater concentrations for SS-9, SS-11, SS-13 \& SS-15 for the years (a) 2008 and (b) 2009 .27

Figure 11: Data points used (16 SSs and additional virtual SSs) to generate an interpolated map that represents the nitrate leaching flux for the entire study area .38

Figure 12: Observed v/s simulated soil moisture contents at depths 15,45 and $75 \mathrm{~cm} \ldots \ldots \ldots .43$

Figure 13: Sensitivity analysis of $\alpha, n$ and $K_{s}$ on soil moisture content at $45 \mathrm{~cm}$ depth.........47 
Figure 14: Monthly precipitation, actual evapotranspiration (AET), simulated root water uptake and evaporation

Figure 15: Simulated v/s observed nitrate concentration in groundwater for (a) 2008 and (b) 2009 for SSs $1,2,3 \& 4$ .52

Figure 16: Simulated v/s observed nitrate concentration in groundwater over the years (a) 2008 and (b) 2009 for SS-5, SS-6, SS-7 \& SS-8 .53

Figure 17: Simulated v/s observed nitrate concentration in groundwater during the years for the BEAs (SS-9 and SS-13 in plots 4 and 7 respectively) over the years (a), (c) 2008 and (b), (d) 2009 .53

Figure 18: Simulated v/s observed nitrate concentration in groundwater for SSs 10 \& 14 in plots 1 and 7 respectively over the years (a), (c) 2008 and (b), (d) 2009 .54

Figure 19: Simulated v/s observed nitrate concentration in groundwater during the years for the BEAs (SSs 11 and 15 in plots 3 and 11 respectively) over the years (a), (c) 2008 and (b), (d) 2009 .54

Figure 20: Simulated v/s observed nitrate concentration in groundwater for SS-16 in plot 11 over the years 2008 and 2009 .54

Figure 21: Simulated cumulative $\mathrm{N}\left(\mathrm{NH}_{4}{ }^{+}, \mathrm{NO}_{3}{ }^{-}\right.$and total) uptake $(\mathrm{kg} / \mathrm{ha})$ for different plots during 2008 (a), (c), (d), (g) and 2009 (b), (d), (f), (h) .57

Figure 22: Cumulative $\mathrm{NH}_{4}{ }^{+}$and $\mathrm{NO}_{3}^{-}$leaching (kg/ha) for different plots during 2008 (a), (c), (d), (g) and 2009 (b), (d), (f), (h) 58

Figure 23: Simulated cumulative $\mathrm{N}\left(\mathrm{NH}_{4}{ }^{+}\right.$and $\left.\mathrm{NO}_{3}{ }^{-}\right)$leaching fluxes $(\mathrm{kg} / \mathrm{ha})$ for BEAs in different plots during 2008 (a), (c) and 2009 (b), (d). 60

Figure 24: Sensitivity analysis of $\alpha, \mathrm{n}$, and $\mathrm{K}_{\mathrm{s}}$ on nitrate leaching $(\mathrm{kg} / \mathrm{ha})$ at SS-9 .61

Figure 25: Nitrate leaching fluxes across the study area regionalised using Cokriging (average leaching rate: $12.9 \mathrm{~kg} / \mathrm{ha} /$ year) 63 
Figure 26: Nitrate leaching fluxes classified into two ranges, Blue area: affected by nitrate excreted by beef cattle (11-1000 kg/ha), red area: unaffected by nitrate excreted by cattle $(0.86-10 \mathrm{~kg} / \mathrm{ha})$

Figure 27: Nitrate leaching flux just outside the boundary of BEAs in plot 1 and plot $11 \ldots 65$ Figure 28: Changes in cumulative recharge for the year (a) 2008 and (b) 2009 as a result of changes in VGM parameter for SS-3

Figure 29: Monthly simulated recharge $(\mathrm{mm})$ in 2008 68

Figure 30: Nitrate leaching in a scenario when the study site consisted of no BEAs. Average flux: $3.6 \mathrm{~kg} / \mathrm{ha}$ .74

Figure 31: Observed v/s simulated soil moisture contents at depths 15, 45 and $75 \mathrm{~cm}$ using the VGM parameters derived from inverse optimization for SS-1 .93

Figure 32: Observed v/s simulated soil moisture contents at depths 15,45 and $75 \mathrm{~cm}$ using the VGM parameters derived from inverse optimization for SS-2

Figure 33: Observed v/s simulated soil moisture contents at depths 15, 45 and $75 \mathrm{~cm}$ using the VGM parameters derived from inverse optimization for SS-4 94

Figure 34: Observed v/s simulated soil moisture contents at depths 15, 45 and $75 \mathrm{~cm}$ using the VGM parameters derived from inverse optimization for SS-5

Figure 35: Observed v/s simulated soil moisture contents at depths 15, 45 and $75 \mathrm{~cm}$ using the VGM parameters derived from inverse optimization for SS-6. .95

Figure 36: Observed v/s simulated soil moisture contents 15, 45 and $75 \mathrm{~cm}$ using the VGM parameters derived from inverse optimization for SS-7..... .95

Figure 37: Observed v/s simulated soil moisture contents at depths 15, 45 and $75 \mathrm{~cm}$ using the VGM parameters derived from inverse optimization for SS-8 .96

Figure 38: Nitrate leaching fluxes across the study area regionalised using Kriging (average leaching rate: $274 \mathrm{~kg} / \mathrm{ha} /$ year). 97 
Figure 39: Nitrate leaching fluxes across the study area regionalised using Inverse Distance Weighing (IDW) (average leaching rate: $264 \mathrm{~kg} / \mathrm{ha} / \mathrm{year}$ ) .98

Figure 40: Nitrate leaching fluxes across the study area regionalised using Natural Neighbor interpolation (average leaching rate: $259 \mathrm{~kg} / \mathrm{ha} /$ year) .99 


\section{List of tables}

Table 1: Mean and standard error of soil physical and chemical properties at the study site determined in 2003 (modified after Coppi, 2012)

Table 2: VGM parameters estimated by PTF

Table 3: Root water uptake coefficients (Simunek et al., 2008)

Table 4: Initial N conditions at the study site (modified after Coppi, 2012)

Table 5: VGM parameters after calibration .44

Table 6: Model performance .45

Table 7: Recharge (mm) and recharge-precipitation ratio (\%) for SS-1 to SS-8 in years 2008 and 2009. 46

Table 8: Monthly water balance for 2008 and 2009 (SS-3) .50

Table 9: Solute transport ( $\mathrm{N}$ transformations) parameters obtained after model calibration..51

Table 10: Performance of the solute transport model .55

Table 11: Components of $\mathrm{N}$ balance in a $200 \mathrm{~cm}$ depth soil of the pasture field during the years 2008 and 2009 62

Table 12: Manure characteristics (modified after Coppi, 2012)..... 89

Table 13: Rates of manure application and amounts of nutrients applied per $\mathrm{m}^{2}$. Values for the split treatments in fall are standardized to rates for a full application treatment. In spring 2009 a double amount of manure (2x N crop removal rates) was applied (modified after Coppi, 2012) .89

Table 14: Mean monthly air temperature and monthly rainfall for the growing seasons (April to October) from 2006 to 2009 and long term climate (mean temperature and rainfall) for the years 1971 to 2000 (Coppi, 2012). .90

Table 15: Soil physical properties for each plot type in the study area 91 


\section{Nomenclature}

\begin{tabular}{|c|c|}
\hline$\alpha$ & Shape parameter, $\left[\mathrm{L}^{-1}\right]$ \\
\hline$a_{i}$ & undetermined weights assigned to $u_{i}$, [ ] \\
\hline$b_{j}$ & undetermined weights assigned to $v_{\mathrm{j}},[]$ \\
\hline$c_{k}$ & Concentration of solute in liquid phase, $\left[\mathrm{ML}^{-3}\right]$ \\
\hline$c_{k}$ & Concentration of solute in solid phase, $\left[\mathrm{MM}^{-1}\right]$ \\
\hline $\mathrm{C}_{\mathrm{p}}$ & Specific heat of the air, $\left[\mathrm{L}^{2} \mathrm{~T}^{-2} \mathrm{~K}^{-1}\right]$ \\
\hline $\mathrm{c}_{\mathrm{r}}$ & Sink term concentraion, $\left[\mathrm{ML}^{-3}\right]$ \\
\hline $\mathrm{D}$ & Hydrodynamic dispersion coefficient, $\left[\mathrm{L}^{2} \mathrm{~T}^{-1}\right]$ \\
\hline$e_{s}-e_{a}$ & Vapour pressure deficit of the air, $\left[\mathrm{ML}^{-1} \mathrm{~T}^{-2}\right]$ \\
\hline G & Soil heat flux, $\left[\mathrm{ML}^{-1} \mathrm{~T}^{-2}\right]$ \\
\hline $\mathrm{h}_{3}$ & Crop's wilting point, [L] \\
\hline $\mathrm{h}_{\mathrm{o}}$ & Pressure head at anaerobiosis point, [L] \\
\hline $\mathrm{h}_{\mathrm{opt}}$ & Optimal root water uptake, [L] \\
\hline $\mathrm{K}(\psi)$ & Unsaturated hydraulic conductivity, $\left[\mathrm{L} \mathrm{T}^{-1}\right]$ \\
\hline $\mathrm{K}_{\mathrm{s}}$ & Saturated hydraulic conductivity, $\left[\mathrm{L} \mathrm{T}^{-1}\right]$ \\
\hline $\mathrm{m}$ & Shape parameter, [ ] \\
\hline $\bar{M}$ & Mean value of observed data set \\
\hline$M_{i}$ & Observed data set, [ ] \\
\hline $\mathrm{n}$ & Shape parameter, [ ] \\
\hline$n$ & Number of simulated and observed data set, [ ] \\
\hline $\mathrm{N}_{\text {denitrification }}$ & Denitrification flux, $\left[\mathrm{M} \mathrm{L}^{-2}\right]$ \\
\hline $\mathrm{N}_{\text {leaching }}$ & Leaching flux of nitrogen below the root zone, $\left[\mathrm{M} \mathrm{L}^{-2}\right]$ \\
\hline $\mathrm{N}_{\text {manure }}$ & $\begin{array}{l}\text { Amount of nitrogen added to soil through the application of manure or fertilizers, }[\mathrm{M} \\
\left.\mathrm{L}^{-2}\right]\end{array}$ \\
\hline $\mathrm{N}_{\text {runoff }}$ & Amount (flux) of nitrogen in terms of runoff losses, $\left[\mathrm{M} \mathrm{L}^{-2}\right]$ \\
\hline $\mathrm{N}_{\text {stored }}$ & Amount of nitrogen initially stored or available in the soil, $\left[\mathrm{M} \mathrm{L}^{-2}\right]$ \\
\hline $\mathrm{N}_{\text {volatilization }}$ & Volatilization flux, $\left[\mathrm{M} \mathrm{L}^{-2}\right]$ \\
\hline$q$ & Volumetric flux density, $\left[\mathrm{LT}^{-1}\right]$ \\
\hline $\mathrm{R}$ & Coefficient of determination, [ ] \\
\hline $\mathrm{r}$ & Correlation coefficient, [ ] \\
\hline $\mathrm{r}_{\mathrm{a}}$ & Aerodynamic resistance, $\left[\mathrm{TL}^{-1}\right]$ \\
\hline $\mathrm{R}_{\mathrm{n}}$ & Net radiation, $\left[\mathrm{MT}^{-3}\right]$ \\
\hline $\mathrm{r}_{\mathrm{s}}$ & Surface resistance, $\left[\mathrm{TL}^{-1}\right]$ \\
\hline S & Sink term, $\left[\mathrm{L}^{3} \mathrm{~L}^{-3} \mathrm{~T}^{-1}\right]$ \\
\hline $\bar{S}$ & Mean value of simulated data set \\
\hline $\mathrm{S}(\mathrm{h})$ & Rate of root water uptake per unit volume of soil, $\left[\mathrm{T}^{-1}\right]$, \\
\hline $\mathrm{S}_{\mathrm{e}}$ & Effective saturation, [ ] \\
\hline
\end{tabular}




\begin{tabular}{ll}
$S_{i}$ & Simulated data set, [ ] \\
$\mathrm{S}_{\mathrm{p}}$ & Potential root water uptake rate, $\left[\mathrm{T}^{-1}\right]$ \\
$\mathrm{t}$ & Time, $[\mathrm{T}]$ \\
$u_{i}$ & Primary data at $n$ nearby locations \\
$u_{\mathrm{o}}$ & Estimate of interpolated paramter at the grid node or at location 0 \\
$v_{j}$ & Secondary data at m locations \\
$\mathrm{z}$ & Elevation, [L] \\
$\alpha(\mathrm{h})$ & Root water coefficient, $[-]$ \\
$\gamma$ & Psychrometric constant, $\left[\mathrm{ML}^{-1} \mathrm{~T}^{-2} \mathrm{~K}^{-1}\right]$ \\
$\Delta$ & Slope of saturation vapour pressure and temperature relationship, $\left[\mathrm{ML}^{-1} \mathrm{~T}^{-2} \mathrm{~K}^{-1}\right]$ \\
$\theta$ & Volumetric water content, $\left[\mathrm{L}^{3} \mathrm{~L}^{-3}\right]$ \\
$\theta(\psi)$ & Soil water retention function \\
$\theta_{\mathrm{r}}$ & Residual water content, $\left[\mathrm{L}^{3} \mathrm{~L}^{-3}\right]$ \\
$\theta_{\mathrm{s}}$ & Saturated water content, $\left[\mathrm{L}^{3} \mathrm{~L}^{-3}\right]$ \\
$\lambda$ & Evapotranspiration, $[\mathrm{L}]$ \\
$\mu_{s}$ & First order decay constant of solute in solid phase, $\left[\mathrm{T}^{-1}\right]$ \\
$\mu_{\mathrm{w}}$ & First order decay constant of solute in liquid phase, $\left[\mathrm{T}^{-1}\right]$ \\
$\rho$ & Bulk density of soil, $\left[\mathrm{ML} L^{-3}\right]$ \\
$\rho_{\mathrm{a}}$ & Average air density at any constant pressure, $\left[\mathrm{ML}{ }^{-3}\right]$ \\
$\psi$ & Pressure head, [L] \\
\hline
\end{tabular}




\section{Acronyms}

\begin{tabular}{|c|c|}
\hline AWD & Alternate Wetting and Drying \\
\hline $\mathrm{BC}$ & Boundary Condition \\
\hline BEA & Bare Earth Area \\
\hline $\mathrm{CF}$ & Continuously Flooded \\
\hline CK & Cokriging \\
\hline IDW & Inverse Distance Weighted \\
\hline MASL & Metres Above Sea Level \\
\hline $\mathrm{ME}$ & Mean Error \\
\hline $\mathrm{N}$ & Nitrogen \\
\hline $\mathrm{N}_{2}$ & Nitrogen Gas \\
\hline $\mathrm{N}_{2} \mathrm{O}$ & Nitrous Oxide \\
\hline $\mathrm{NN}$ & Natural Neighbor \\
\hline $\mathrm{NH}_{4}-\mathrm{N}$ & Concentration of ammonium in water reported in terms of nitrogen \\
\hline $\mathrm{NO}_{3}-\mathrm{N}$ & Concentration of nitrate in water reported in terms of nitrogen \\
\hline NSE & Nash-Sutcliffe Efficiency \\
\hline $\mathrm{OK}$ & Ordinary Kriging \\
\hline $\mathrm{P}$ & Phosphorous \\
\hline PTF & Pedo Transfer Function \\
\hline RMSE & Root Mean Square Error \\
\hline SK & Simple Kriging \\
\hline SS & Sensor Station \\
\hline SWE & Snow Water Equivalent \\
\hline TDR & Time Domain Reflectometry \\
\hline VGM & van Genuchten-Mualem \\
\hline
\end{tabular}




\section{Chapter 1: Background}

Groundwater is one of the major freshwater source of consumed freshwater in Canada as about 9 million Canadians rely on it for drinking and household purposes (Environment Canada, 2013). However, the increasing agricultural and industrial activities resulted in groundwater contamination in various parts of the country (Environment Canada, 2010). Canadian agriculture has intensified during past few decades resulting in greater demands of groundwater for irrigational purposes, a regional increase in fertilizer use, and greater farm size and livestock numbers. This has led to an increase in the risk of groundwater contamination by nitrate and pathogens (Bruce, 2009).

Nitrogen is an essential nutrient and a key agricultural input which is considered to be crucial for crop growth, development and yield (Ribaudo et al., 2011). It is important for plants specifically in their metabolic processes such as the production of proteins, nucleic acids and other important molecules (ISAAP, 2015). Upon the application of nitrogen-rich manure or fertilizer to the soil, excess nitrate that is not consumed by the plants is accumulated in the soil and often leaches below the root zone, ultimately contaminating the groundwater. Generally, the risk of nitrate leaching increases during the periods of heavy rainfall and snow melt due to the high availability of surplus water that can carry the soluble nitrate along with it to the groundwater. Coarse textured soils with low water retention capacity, fast drainage, and high porosity are more prone to these losses compared to fine textured or clayey soils with higher water retention capacity and slow drainage. The extent of nitrate leaching also depends on denitrification during which, nitrate converts to nitrogen gas $\left(\mathrm{N}_{2}\right)$ by soil microorganisms under anaerobic conditions. Denitrification decreases the availability of nitrates in the soil so that the risk of nitrate leaching reduces. 
The primary sources of nitrogen pollution in the environment are agricultural activities, stormwater, wastewater and few domestic sources (EPA, 2015). In Canada, many cases regarding nitrate contamination of groundwater have been observed. E.g., thousands of fishes were killed in Prince Edward Island due to leaching of nitrate into rivers and streams due to agricultural activities (Globe and Mail, 2008). In Manitoba, elevated nitrogen levels in Lake Winnipeg and at shallow depths in the Assiniboine Delta Aquifer located in SouthWestern Manitoba were observed (Burton et al., 2000). Frost (2006) reported the detection of more than $10 \mathrm{mg} \mathrm{NO}_{3}-\mathrm{N} \mathrm{L}^{-1}$ in groundwater for about $16 \%$ of all private wells in Manitoba. Environment Canada (2010) stated that more contaminated aquifers in Canada would be discovered in the coming decades due to emerging contaminants. The contaminated groundwater discharges into the lakes, streams, and wetlands.

Nitrate leaching is a serious concern for groundwater and surrounding surface water quality and also for human health if contaminated water is used for drinking purposes (Coppi, 2012). Nitrate concentration above $10 \mathrm{mg} \mathrm{NO}_{3}{ }^{-}-\mathrm{N} \mathrm{L}^{-1}$ in drinking water is linked to certain health problems such as stomach cancer in adults and methaemoglobinaemia in infants which decrease the ability of blood to carry oxygen in the body (Health Canada, 2013).

Manure is used to fertilize the soil for crop production (Wang et al., 2004). Liquid hog manure is another excellent source of nutrients for crop production in Manitoba since it is rich in mainly two important nutrients nitrogen $(\mathrm{N})$ and phosphorous $(\mathrm{P})$ on which Manitoba's crop yield is dependent (Manitoba Agriculture, 2013). The nutrients present in manure are in stable organic forms and cannot be directly used by the crops. Hence, they need to be mineralized to an inorganic form before crops can use them (Ranjan et al., 2001). However, mineralization is a complex process which depends on soil type, weather conditions as well as the method of application of manure. Manure application must be based on the rate of mineralization and the quantity of nutrients which are readily available to the 
crops (Ranjan et al., 2001). Hence, knowledge about mineralization rate and the processes which govern this transformation is required for the sustainable management of manure which implies the effective use of nutrient present in manure. The basic concept behind the sustainable management of manure is to promote its value as an organic fertilizer and disregard considering it as a 'waste product'.

Numerical simulation programs can simulate the physical and chemical processes occurring in the soil based on the integrated water flow, solute transport and heat transport equations, using soil properties and weather data. These are important and valuable tools for simulating such processes as well as determining how much nutrients are readily available in soil to be consumed by plants (Ranjan et al., 2001). After estimating available nutrients in the soil, the deficit can be added via manure application such that excess nutrients do not accumulate in the soil, therefore groundwater quality below the root zone is maintained (Ranjan et al., 2001). Physically based modeling reduces the amount of field work, cost and time required for studying the extent of nitrate leaching into the vadose zone under transient conditions (Saso, 2009). Moreover, a good understanding can be achieved regarding the relationship between timing and amount of nutrients to be applied and their uptake by the crops using numerical simulators (Dahan et al., 2014; Shekofteh et al., 2013).

One-dimensional physically based modeling can simulate groundwater recharge and nitrate leaching fluxes at a point scale. However, due to heterogeneities at the field scale, the behavior of these fluxes can be different at different points in the field depending on soil texture, the amount of manure applied and the groundwater table. Regionalisation refers to the prediction of values of the desired parameter at the un-sampled locations by taking into account data of parameter at sampled locations and the neighborhood distribution (Healy, 2010). There are several methods to carry out the regionalisation of point estimates such as simple empirical models which are suitable for estimating recharge and nitrate leaching 
fluxes in areas of low heterogeneity (Healy, 2010) and regression techniques which are applicable to the areas where sufficient data are available (Lorenz and Delin, 2007). In the recent decades, geostatistical techniques have widely been used in a number of different hydrological applications including nitrate leaching into groundwater and recharge estimation (Evers et al., 2004; Lee et al., 2006; Piccini et al., 2012). Kriging (Krige and Matheron, 1967; Matheron, 1967) is a geostatistical technique which allows the estimation of any parameter at unknown locations if the point estimates at neighbouring locations are known.

The objective of this research was to estimate nitrate leaching fluxes upon the application of liquid hog manure on a pasture land in Southern Manitoba using physically based modeling and to regionalise further the point estimates nitrate leaching fluxes at the field scale. 


\section{Chapter 2: Literature review}

\subsection{Nitrate in Canadian groundwater \& environmental implications}

Groundwater is a crucial and indispensable drinking water resource for 9 million Canadians. It is also regarded as a 'hidden water resource' for those who are not dependent on it or have not well understood and appreciated its value (Environment Canada, 2009).

In recent years, public concern and realization about worth and importance of groundwater have been triggered as a result of the occurrence of a number of events which affected the Canadian groundwater quality (Environment Canada, 2009). A few of these events were related to nitrate contamination of groundwater such as in Prince Edward Island where elevated nitrate concentration $\left(>10 \mathrm{mg} \mathrm{NO}_{3}-\mathrm{N} \mathrm{L}^{-1}\right.$ ) were detected in $6 \%$ of drinking water domestic wells (Paradis et al., 2016) and in Assiniboine Delta Aquifer located in South-West Manitoba (Burton et al., 2000). Agricultural practices are one of the major sources of nitrate leaching resulting in the contamination of groundwater in Canada, mainly in Canadian Prairie province Manitoba. Lefebvre (2005) reported a 25\% increase of nitrate concentration nationally in the Canadian groundwater from $5.9 \mathrm{mg} \mathrm{NO}_{3}-\mathrm{N} \mathrm{L}^{-1}$ in 1981 to $7.3 \mathrm{mg} \mathrm{NO}-\mathrm{N} \mathrm{L}^{-1}$ in 2001 resulting from agricultural lands with residual soil nitrogen. A study conducted by Rudolph et al. (2015) outlined the detection of elevated nitrate concentrations (>10 mg $\mathrm{NO}_{3-}$ $\mathrm{N} \mathrm{L}^{-1}$ ) in two agricultural fields located in the towns of Baden and Woodstock in Southern Ontario. Elevated concentrations of nitrate in groundwater associated with agricultural practices were also reported in the Grand Forks area located in the east of Kettle River basin as well as in areas surrounding Osoyoos located in the west of Kettle River basin of South Central British Columbia (Harker et al., 2015). There has been an increase in the risk of nitrate contamination of groundwater in the past decades due to several factors such as an increase in regional fertilizer use and in livestock (Bruce, 2009). 
Agricultural producers are not yet able to adopt the Best Management Practices (BMPs) which are focussed to promote the value of manure as an organic fertilizer and disregard considering it as a 'waste product', for minimizing the nitrate contamination of groundwater in Canada. Hence, further research, monitoring, and enforcement of best management practices are required to achieve the desired objectives regarding the groundwater quality (Bruce, 2009).

The application of manure, especially to sandy soils, may pose a threat for losses of major nutrients and other compounds in groundwater (subsurface drainage and leaching) and surface water (snowmelt and run-off). Nitrate is soluble in water and is mobile in the soil pores. Unlike ammonium ions, nitrate ions do not get adsorbed to the negatively charged soil particles due to their negative charge. Hence they move below the root zone if there is an availability of excess soil water that can leach below the root zone. A region's overall hydrological and nitrogen balance greatly affect the leaching losses since these losses are dependent on the amount of surplus water available for groundwater recharge. In Manitoba, the extremely cold weather conditions from late September to early May allows the upper soil layer to freeze during these months. Soil thawing in early spring poses a potential threat for nitrate contamination of groundwater in Manitoba as most of the groundwater recharge occurs during this period (Wang et al. 2016, under review).

Another environmental concern that is linked with elevated $\mathrm{N}$ levels in groundwater is the eutrophication of surface waters bodies such as lakes and rivers. One of the potential causes of surface water eutrophication is the elevated nitrogen $(\mathrm{N})$ concentrations in groundwater which is hydrologically connected with the nearby surface water bodies such as rivers and lakes. In aquatic environments, the elevated $\mathrm{N}$ and $\mathrm{P}$ concentrations trigger the growth of autotrophic algae as compared to other microorganisms which lead to an increase in dissolved oxygen consumption due to increased respiration. These algal blooms in the aquatic 
environments reduce the dissolved oxygen level in the water, as a result of which population of fish and other micro-organisms decreases in the surface water bodies (Carpenter et al., 1998). Lake Winnipeg, located in Manitoba, is the world's $10^{\text {th }}$ largest lake and is experiencing eutrophication since at least past thirty years (Coppi, 2012; Schindler et al., 2006). The increased nutrient load is from its main tributaries: Winnipeg River, Red River, and Saskatchewan River. The Red River supplies most of the annual P and $\mathrm{N}$ loadings to Lake Winnipeg as $54 \%$ and $30 \%$ respectively in spite of the fact that the volume of water contributed to the Lake Winnipeg by Red River is relatively small as compared to its other tributaries.

\subsection{Human health concerns}

Nitrate concentration above $10 \mathrm{mg} \mathrm{NO}_{3}{ }^{-}-\mathrm{N} \mathrm{L}^{-1}$ in drinking water is linked to certain health problems such as stomach cancer in adults and methaemoglobinaemia in infants which decrease the ability of blood to carry oxygen around the body (Health Canada, 2013). The drinking water threshold of $10 \mathrm{mg} \mathrm{NO}_{3}^{-}-\mathrm{N} \mathrm{L}^{-1}$ was first suggested by Comly (1945), and later in 1951, Walton (1951) confirmed this standard based on incidents of methaemoglobinaemia in infants. Walton mentioned their study that no cases of methaemoglobinaemia were reported for the concentration of nitrate in drinking water being less than $10 \mathrm{mg} \mathrm{NO}_{3}^{-} \mathrm{N} \mathrm{L}^{-1}$. The actual cause of methaemoglobinaemia in infants is nitric oxide, not nitrate (Addiscott and Benjamin, 2004). Nitrate is converted to nitric oxide in the gut which further oxidises hemoglobin present in blood to methaemoglobin reducing the amount of hemoglobin available for transport of oxygen. Nitrate is a relatively non-toxic compound of nitrogen as compared to its metabolites which can potentially cause several adverse health issues such as stomach cancer. Proper control and monitoring of nitrate-N levels in drinking water are always important to reduce such adverse health effects. 


\subsection{Nitrogen dynamics}

Nitrogen is an important macronutrient which is required for a crop's proper growth and yield and is often inadequate in the agricultural soils (Manitoba Agriculture, 2013). Hence the application of nitrogen-rich fertilizers or manures is required to achieve the target crop yield. Application of nitrogen via fertilizers or manures allows it to enter the soil-N cycle. Soil-N cycle can be explained in terms of gains, internal transformations, removals, and losses of $\mathrm{N}$ in soil (Figure 1).

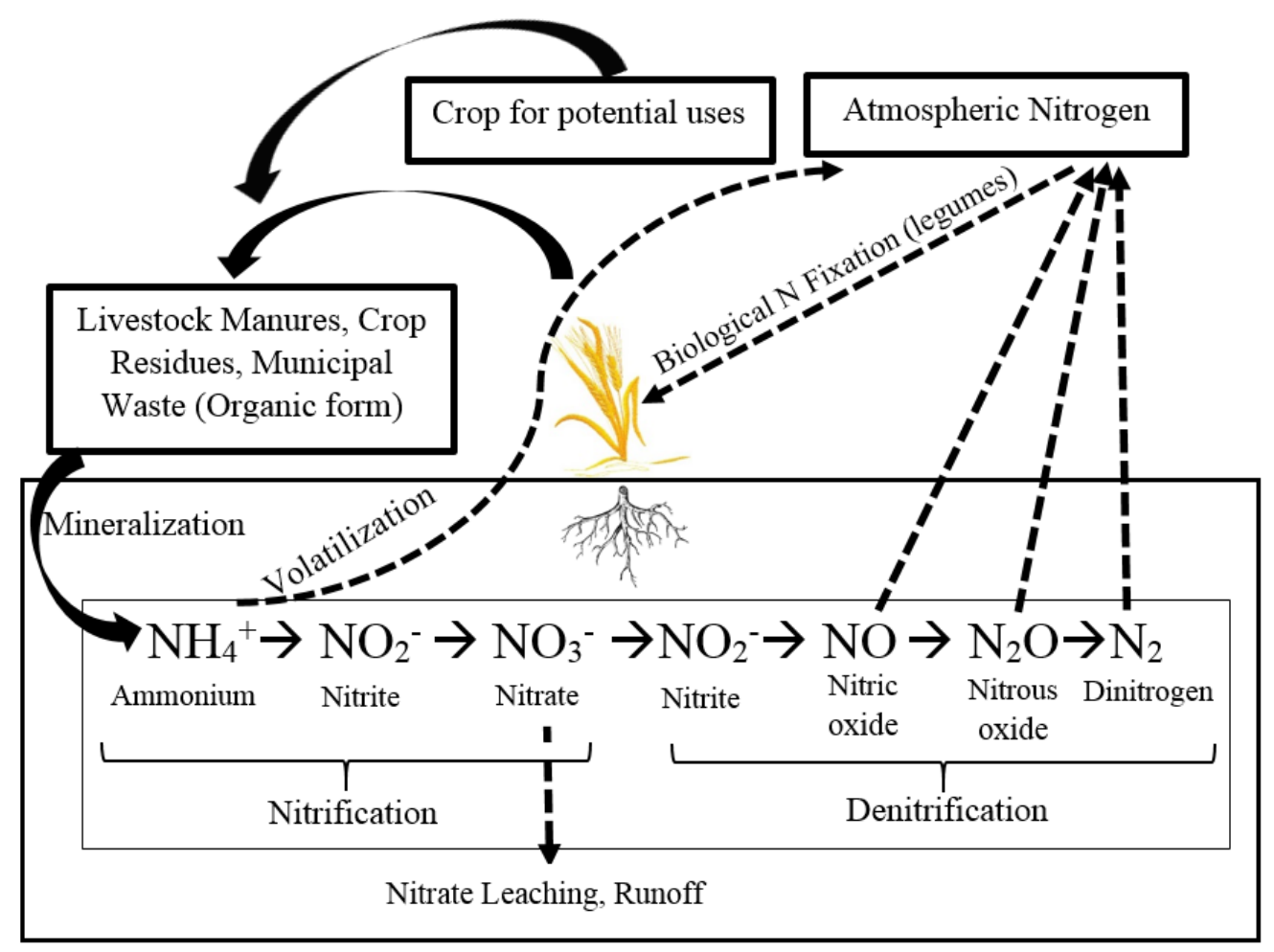

Figure 1: Soil-N cycle showing complex and dynamic behaviour of nitrogen in soil with many transformations (solid black lines) and potential losses (dashed lines)

Nitrogen in manure is mainly present in two different forms: organic nitrogen and ammonium nitrogen. It is also present in very small amounts in the form of nitrates. All these forms of nitrogen collectively add up to total nitrogen (Manitoba Agriculture, 2009). Soon after the application of manure, all of the nitrogen does not get available to plants for their use since they can only use the inorganic form of it. Ammonium-N $\left(\mathrm{NH}_{4}-\mathrm{N}\right)$ is the primary inorganic 
form of nitrogen and is available immediately to the crops after manure application. Another form of inorganic nitrogen present in manure is nitrate- $\mathrm{N}\left(\mathrm{NO}_{3}{ }^{-} \mathrm{N}\right)$, but it is present in negligible amounts. The organic form of nitrogen can be determined as the difference between total and ammonium nitrogen.

After application of manure to soil, nutrients go through various transformations which may affect their availability for use by plants. The organic nitrogen is converted to inorganic ammonium form by a process known as mineralization (Figure 1). In Manitoba, it has been determined that around $25 \%$ of manure's organic nitrogen is mineralized and becomes available to the next crop. The remaining amount becomes available for use during the following years at decreased rates (Manitoba Agriculture, 2009). Upon manure application, some of the ammonium-N undergoes a chemical process known as volatilization by which it gets lost to the atmosphere in the form of ammonia gas (Manitoba Agriculture, 2009). A number of losses through volatilization depends on various factors as follows:

- Soil cover: If the manure is properly covered by soil, it leads to the reduction in volatilization losses of ammonium-N. Injection of manure into the soil reduce these losses instead of the surface application.

- Soil pH: Alkaline soils with high $\mathrm{pH}$ and low concentration of $\mathrm{H}^{+}$ions favours the volatilization losses compared to low $\mathrm{pH}$ soils with high concentration of $\mathrm{H}^{+}$ions.

- Soil texture: Sandy soils with low cation exchange capacity can retain less ammonium-N leading to higher losses due to volatilization.

- Weather: Volatilization losses increase during warm weathers due to increase in the rate of $\mathrm{NH}_{3}$ formation. Fast winds also increase $\mathrm{NH}_{3}$ losses to the atmosphere due to increased rate of air exchange (Manitoba Agriculture, 2013). 
The actually available ammonium-N that can be used by plants is calculated by the difference between manure's total ammonium content and percentage losses through the process of volatilization.

Although nitrate concentration in manure is very low, manured soils contain significant amounts of nitrate through the process of nitrification by which soil microorganisms transform nitrogen from ammonium to nitrate. There occurs an accumulation of nitrate- $\mathrm{N}$ $\left(\mathrm{NO}_{3}{ }^{-}-\mathrm{N}\right)$ during the nitrification of ammonium-N. If the accumulated nitrates are not utilized by plants, they become prone to leaching below the root zone to contaminate the groundwater.

Immobilization is another process which occurs in the soil. It is known as the reverse process of mineralization. When microbes in the soil start feeding on plant available inorganic $\mathrm{N}$ due to limited amounts of organic $\mathrm{N}$, they reduce the ammonium- $\mathrm{N}$ and nitrate- $\mathrm{N}$ from the soil solution and convert them to organic form.

Denitrification occurs in the soil only during anaerobic conditions. During this process, nitrates are reduced to nitrites and then further to $\mathrm{N}_{2}$ (nitrogen gas) or $\mathrm{N}_{2} \mathrm{O}$ (nitrous oxide) by the microorganisms. During anaerobic conditions, microorganisms use $\mathrm{NO}_{3}$ for respiration instead of $\mathrm{O}_{2}$. This microbial process is favoured under certain conditions such as during large supply of $\mathrm{NO}_{3}$ and limited amount of $\mathrm{O}_{2}$ (saturated soils) or during warm temperatures when there is a high microbial activity in the soil (Manitoba Agriculture, 2013). Denitrification does not occur in dry soils when there is plenty of oxygen $\left(\mathrm{O}_{2}\right)$ present in the soil and can be utilised by microorganisms for respiration.

\subsection{Liquid hog manure}

Hog manure contains the nutrients which are required for crop production. It is a natural byproduct of livestock production and can be regarded as an organic fertilizer. Applying hog 
manure to the soil recycles not only the soil nutrients but also improves soil tilth, aeration, structure, and water-holding capacity (Manitoba Agriculture, 2009).

Over the last century, there has been a gradual shift in livestock herding from extensive systems to the enclosed systems of barns and pastures (Haygarth and Jarvis, 2002). Hog population in Manitoba grew significantly from 600,000 in 1976 to 2.8 million in 2011 (Brisson, 2014). The average per-farm hog population also increased from 762 hogs/farm in 1976 to 4831 hogs/farm in 2011 (Brisson, 2014).

The significant increase in hog production in Manitoba over the last century has reduced the transportation costs of animals and feeds and motivated to store the animal waste (Coppi, 2012). The intensive production of hogs in Manitoba resulted in a need to import large amounts of nutrients to feed the livestock (Carpenter et al., 1998; Coppi, 2012). Since hogs cannot retain much of the nutrients ingested from feeds, they excrete a large part of them in the form of feces and urine which are further stored in earthen storages (Cooperband and Good, 2002).

On an average, each pig produces 161-178 kg of feces and urine per year (Müller, 1980) and every sow and their progeny excretes 20 t per year of manure. In Manitoba, hog manure is commonly stored in the anaerobic earthen storages where urine and feces are collected with wash water in open air pools. Urine and feces are mixed to form slurry that has suspended solids. Typically, the slurry has approximately $94 \%$ moisture content (Haygarth and Jarvis, 2002). The composition of manure changes during its storage due to the prevailing anaerobic conditions. These conditions allow mineralization of organic $\mathrm{N}$ to its inorganic ammonium form. This also leads to the volatilization losses of ammonia (Cabrera and Gordillo, 1995). Two-thirds of $\mathrm{N}$ is in inorganic ammonium form which is dissolved in manure's liquid phase, 
and the other one-third remains in an organic form associated with the solid phase (Cabrera and Gordillo, 1995).

\subsection{Agricultural nitrogen balance}

A healthy balance between nutrients added and removed from the soil is very important to ensure their optimal use and limit their accumulation in the soil (OECD and EUROSTAT, 2007). As explained in section 2.2, plants use nutrients available in the soil for their overall growth. However, if the nutrients removed from soil are more than nutrients added, soil begins to lose its fertility and limits the crop growth. It is then very important to maintain a balance of nutrients in soil in order to identify the areas of their surplus and deficits (OECD and EUROSTAT, 2007).

The nitrogen budget can be analysed by determining a mass balance between its input to the soil from agricultural and natural sources and removal by crops, pastures, and forages. A simple mass balance equation can be used to determine the surplus amount of nitrogen:

$\mathrm{N}_{\text {surplus }}=\mathrm{N}_{\text {manure }}+\mathrm{N}_{\text {stored }}-\mathrm{N}_{\text {denitrification }}-\mathrm{N}_{\text {volatilization }}-\mathrm{N}_{\text {leaching }}-\mathrm{N}_{\text {runoff }}-\mathrm{N}_{\text {crop uptake }}$

where $\mathrm{N}_{\text {manure }}(\mathrm{kg} / \mathrm{ha})$ is the amount of nitrogen added to the soil through the application of manure or fertilizers, $\mathrm{N}_{\text {stored }}$ is the initially stored nitrogen in the soil, $\mathrm{N}_{\text {denitrification }}$ and $\mathrm{N}_{\text {volatilization }}$ are the amounts of nitrogen removed by denitrification and volatilization processes, $\mathrm{N}_{\text {leaching }}$ and $\mathrm{N}_{\text {runoff }}$ are the leaching and runoff losses, and $\mathrm{N}_{\text {crop uptake }}$ is the Nitrogen uptake by plant roots. Positive $\mathrm{N}_{\text {surplus }}$ represents the surplus of nitrogen in the soil which can be treated as a potential source of groundwater contamination whereas negative $\mathrm{N}_{\text {surplus }}$ means the removal of nitrogen by the crops is more than the input through any of the sources. Negative $\mathrm{N}_{\text {surplus }}$ indicates the declining fertility of the soil which can eventually lead to reduced crop productivity. Zero value of $\mathrm{N}_{\text {surplus }}$ indicates the optimal use of nitrogen sources by the crop grown. 


\subsection{Tame pasture and bare-earth areas}

Tame pastures are the agricultural fields cultivated with non-native grass or legume species and are used to achieve a list of purposes including grazing of livestock to recover and improve their health and nutrition, to minimize soil erosion and upgrade soil quality and to balance forage demand and supply during the periods of low forage production (Jacobs and Siddoway, 2007). The listed purposes of tame pastures are optimally achieved when the established crop is healthy and is functioning well to capture solar energy, facilitate nutrient and water cycling. In Manitoba, tame pasture is being used by the livestock producers since the beginning of homesteading in the province. The long and warm days in summers with an appropriate amount of soil moisture are the ideal conditions for pasture growth which prevails in the Canadian Prairies. In 1998, production of tame hay pasture was first recorded when $481.5 \mathrm{~km}^{2}$ of land produced 195 million $\mathrm{kgs}$ of hay. The increase in livestock production over the years has steadily increased the production of pasture in Manitoba. Presently, around $7989 \mathrm{~km}^{2}$ of land provides over 2721.5 million $\mathrm{kgs}$ of tame hay in Manitoba (Manitoba Agriculture, 2016)

Livestock grazing is a management practice which is used on tame pasture to achieve a well maintained and a healthy forage base, for providing nutrition to the livestock for their growth and development. Livestock grazing or mechanical harvesting of pastures is very important since it maintains the cycle of forage growth and utilization. The absence of crop harvesting, either by grazing or by mechanical means, can lead to the accumulation of dead plants on the land, which can further shade the photosynthetically active plant material, ultimately resulting in a reduction in capture of solar energy by plants that drive the system (Jacobs and Siddoway, 2007). In the grazed pastures, there exist a cycle of nutrient transfer from soil to pasture plants and vice versa, either through the excretes of grazing animals or through the dead plants (Williams and Haynes, 1990). As this cycle occurs, losses and gains of nutrients 
may occur via leaching, volatilization or through the addition of addition of fertilizers or manure. Grazing animals play an important role in carrying out the nutrient cycle through the soil. They ingest the herbage and ultimately encourage the growth of pasture plants and therefore intake more nutrients from the soil (Williams and Haynes, 1990). In grazed pastures, nutrient accumulation can occur when livestock tend to concentrate near areas such as mineral feeders, water troughs and shelters (Coppi, 2012; Williams and Haynes, 1990) resulting in higher deposition density of urine and feces than for other areas in pasture fields. Due to regular soil compaction, trampling and high concentration of nutrients, these areas often become bare. Apart from these areas getting larger with regular deployment of animals, the nutrient concentrations in the soil also rise due to further deposition of urine and feces over these areas (Dahlin et al., 2005), hence creating a serious threat of leaching of nutrients to the groundwater below.

\subsection{Physically based modeling of nutrient leaching}

Physically based models generally tend to represent the physical processes such as evapotranspiration, surface and subsurface flow and transport of solutes in soil that occurs in the real world. These processes can be simulated using empirical or partial differential equations, e.g. Richard's equation (Richards, 1931) which represents water flow in unsaturated soils (Section 3.4). Numerical simulation programs can simulate the physical and chemical processes occurring in the soil based on water flow, solute transport and heat transport equations, using soil properties and weather data. These are important and valuable tools for simulating such processes as well as determining how much nutrients are readily available in soil to be consumed by plants (Ranjan et al., 2001). Estimating the plantavailable nutrients in the soil, the deficit amounts can be added via manure application such that they do not get accumulated in the soil and groundwater quality below the root zone is maintained (Ranjan et al., 2001). Physically based modeling reduces the amount of field 
work, cost and time required for studying the extent of nitrate leaching into the vadose zone under transient conditions (Saso, 2009)

Groundwater recharge and nutrient leaching are fundamentally time, and spatial variable processes and their estimation is difficult. A high degree of uncertainty is often associated with their estimation (Holländer et al., 2016). Physically based vadose zone modeling is a commonly used method for their estimation, e.g. Holländer et al. (2016) successfully used this method to estimate groundwater recharge on sandy soil in Southern Abbotsford, British Columbia, Canada subjected to mild and moist winters. They used data from a low-cost weather station and automated sensing techniques and concluded that this method is able to estimate transient recharge and nitrate leaching estimates which are controlled by heavy precipitation and water as well as nitrate infiltration events.

Liu et al. (2013b) used this method to estimate the impact of on-going and future long-term flood irrigation practices on the extent of nitrate leaching into the soil profile in an agricultural district of Jinghuiku, China with sandy clay loam soil and a semi-arid climate. They concluded that the introduction of flood irrigation increased the concentration and downward drainage fluxes of nitrate within the $2 \mathrm{~m}$ soil profile and also indicated the risk of elevation of $\mathrm{N}$ concentrations $1 \mathrm{~m}$ below the soil profile due to increasing future irrigation. Recently, Tan et al. (2015) used physically based modeling to simulate the movement of water and $\mathrm{N}$ transformations and transport in experimental lowland paddy fields subjected to Alternate Wetting and Drying (AWD) type as well as Continuously Flooded (CF) irrigations. Their results reflected the development of alternate aerobic and anaerobic conditions in the soil due to AWD type of irrigation leading to alternate nitrification and denitrification occurring in soil. During the dry (aerobic) conditions, nitrification of ammonium to nitrate took place which further denitrified to nitrogen gas $\left(\mathrm{N}_{2}\right)$ or nitrous oxide $\left(\mathrm{N}_{2} \mathrm{O}\right)$ during the wet (anaerobic) conditions. They concluded the simulation of water and $\mathrm{N}$ movement using 
physically based modeling being an effective and reliable approach for the improved management of water and $\mathrm{N}$ for the sustainable production of rice.

There has been no such study found which used this method for estimation of groundwater recharge and extent of nitrate leaching in pasture fields of Southern Manitoba which are subjected to liquid hog manure applications with coarse soil texture and low hydraulic gradient groundwater flow.

\subsection{Regionalisation of nitrate fluxes}

Groundwater recharge and nitrate leaching fluxes are spatially variable quantities and are dependent on soil texture, manure/fertilizer application, groundwater table, and soil moisture content. One-dimensional (1D) physically based modeling generates groundwater recharge and nitrate leaching flux estimates at certain sampled locations in a field. However, due to heterogeneities at the field scale, these quantities can be potentially variable at un-sampled locations in the field. Regionalisation refers to the prediction of values of the desired parameter at the un-sampled locations by taking into account data of parameter at sampled locations and the neighbourhood distribution (Healy, 2010). It is a complex operation which takes into accounts various factors such as the distribution of sampled locations, omnidirectional consideration of observations and uncertainties of interpolation methods. Therefore the quality of results generated through spatial interpolation depends on the quality of inputs, spatial coverage, and model selection. There has been a development of different methods to carry out spatial interpolation such as local interpolation methods and geostatistical methods. Local interpolation methods are based on the assumption that each sampled point can influence the study area only up to a certain finite distance (Mitas and Mitasova, 1999). Different methods for this classification are Natural Neighbour (NN) interpolation (Sibson, 1981), Inverse Distance Weighted (IDW) interpolation (Bartier and 
Keller, 1996), Thiessen polygons (Goovaerts, 2000) and Splines (Unser, 1999). Kriging (Krige and Matheron, 1967; Matheron, 1967) is the primary approach for geostatistical methods and was originally developed for the mining industry. Kriging methods of geostatistical interpolation consist of Simple (SK), Ordinary Kriging (OK), Universal Kriging and with further developments Cokriging (CK) was introduced which became applicable in environmental science, hydrogeology, remote sensing and natural resources (Bayraktar and Turalioglu, 2005; Chilès and Delfiner, 1999; Papritz and Dubois, 1999; Richmond, 2002; Tonkin and Larson, 2002). Several studies were carried out in recent decades to interpolate groundwater table using the geostatistical methods, and kriging was found to be optimal (Sun et al., 2009; Xiao et al., 2016; Yao et al., 2014). Recently, Wang (2017) carried out a study to spatially interpolate the groundwater recharge for a pasture land in Southern Manitoba and found Cokriging $(\mathrm{CK})$ to be a potentially suitable method due to cross-variation of recharge with multiple soils and meteorological parameters. Similarly, leaching of nitrate below the root zone depends on various factors such as application and timing of manure, groundwater table, vegetation, soil texture and weather conditions. Therefore, Cokriging $(\mathrm{CK})$ can be considered as a potentially suitable method for interpolating nitrate leaching fluxes taking into account the rate of manure application as a secondary variable. The non-accountability of the secondary variable in local interpolation methods (NN, IDW, Thiessen polygons, and Splines) as well as in Simple, Ordinary and Universal Kriging made these methods inapplicable for interpolating nitrate leaching fluxes. 


\section{Chapter 3: Methodology}

\subsection{Study area}

The study site for this research was the Pasture and Swine Manure Management Site in La Broquerie, Manitoba (Figure 2). La Broquerie is one of the most concentrated areas of livestock production in Canada (Flaten et al., 2003). Its livestock density was 129 animals per $\mathrm{km}^{2}$ in 2001 . The study site had a total tame grassland area of $0.4 \mathrm{~km}^{2}$. Before 2003 , there was no application of manure or fertilizer to the study site (Coppi, 2012). The main vegetation of the pasture land was quackgrass (Elytrigia repens L. Nevski) and Kentucky bluegrass (Poa pratensis L.) (Wilson et al., 2010). About $89 \%$ of land in the rural municipality of La Broquerie falls under agriculture capability classes 3 to 6, which means the soil is suitable for grass forage production (Land Resource Unit, 1999). The soil texture in the study area was mostly sandy loam to gravel. At $2 \mathrm{~m}$ deep in the western half of study area, there was the presence of an impermeable clay layer (Coppi, 2012). Due to rapid drainage and low water retention of the coarse soil, it is not appropriate for annual crop production. Hence, most of the area was being utilized for grass forage production (Coppi, 2012). The dominant soil series were $70 \%$ Berlo loamy fine sand (imperfectly drained lacustrine) and 30\% Kergwenan loamy sand to gravel (imperfectly drained outwash). The calcareous, coarse soil was under-layed partially by a $4 \mathrm{~m}$ thick clay layer which prevented free drainage and caused the groundwater table to rise up in spring during snow melt and heavy precipitation events (measured at SS-3, Figure 3) (Coppi, 2012).

The mean physical and chemical properties of soil in the study area are listed in table 1 . The average stone weight percentage in the whole soil profile was determined to be $37 \%$. 
Table 1: Mean and standard error of soil physical and chemical properties at the study site determined in 2003 (modified after Coppi, 2012)

\begin{tabular}{|c|c|c|c|c|c|c|c|c|c|c|c|}
\hline $\begin{array}{c}\text { Soil } \\
\text { Depth } \\
\mathrm{cm}\end{array}$ & $\begin{array}{l}\text { Para } \\
\text { meter }\end{array}$ & pH & $\begin{array}{l}\text { Total- } \\
\mathbf{N} \\
\mathrm{g} \mathrm{kg}^{-1}\end{array}$ & $\begin{array}{c}\mathbf{N H}_{4}{ }^{+}- \\
\mathbf{N} \\
\mathrm{mg}\end{array}$ & $\begin{array}{l}\mathrm{NO}_{3} \\
--\mathrm{N} \\
\mathrm{g}^{-1}\end{array}$ & Sand & $\begin{array}{l}\text { Silt } \\
\%\end{array}$ & Clay & $\begin{array}{c}\text { Texture } \\
\text { Class }\end{array}$ & $\begin{array}{l}\text { Stones } \\
\% \text { weight }\end{array}$ & $\begin{array}{c}\text { Bulk } \\
\text { Density } \\
\mathrm{g} \mathrm{cm}^{-3}\end{array}$ \\
\hline \multirow{2}{*}{ 0-30 } & Mean & 7.9 & 0.77 & 1.95 & 1.73 & 82 & 10 & 8 & \multirow{2}{*}{$\begin{array}{c}\text { Loamy } \\
\text { Sand }\end{array}$} & 31 & 1.68 \\
\hline & S.E. & 0.0 & 0.08 & 0.22 & 0.18 & 1 & 1 & 0 & & 2 & 0.11 \\
\hline \multirow{2}{*}{$30-60$} & Mean & 8.3 & 0.32 & 0.94 & 1.24 & 87 & 10 & 3 & \multirow{2}{*}{ Sand } & 41 & 2.04 \\
\hline & S.E. & 0.0 & 0.06 & 0.15 & 0.10 & 2 & 2 & 0 & & 2 & 0.12 \\
\hline \multirow{2}{*}{$60-90$} & Mean & 8.4 & 0.17 & 0.45 & 0.71 & 93 & 6 & 2 & \multirow{2}{*}{ Sand } & 39 & 1.94 \\
\hline & S.E. & 0.0 & 0.05 & 0.09 & 0.04 & 0 & 0 & 0 & & 2 & 0.09 \\
\hline \multirow{2}{*}{$90-120$} & Mean & 8.6 & 0.13 & 0.31 & 0.54 & 93 & 5 & 2 & \multirow{2}{*}{ Sand } & 36 & 1.96 \\
\hline & S.E. & 0.0 & 0.03 & 0.05 & 0.04 & 0 & 0 & 0 & & 2 & 0.09 \\
\hline
\end{tabular}

ITextural classes based on the USDA classification.

Average bulk density of soil was determined in the field in August 2007 by excavating four soil pits to the depth of groundwater which was about $125 \mathrm{~cm}$ (Coppi, 2012) (Figure 3). The soil physical properties for each plot are listed in Appendix-A.

\subsection{Experimental design}

The study site was split into 12 plots (Figure 3 ). The experimental design conducted by the Department of Soil Science, University of Manitoba in 2003 was based on manure application and on forage utilization:

(a) Manure application treatment: There were three types of manure application treatments namely control, single (or full) and split. On control treatment plots, manure was never applied whereas, on single treatment plots, manure was applied with full rate according to the $\mathrm{N}$ requirement of pasture during spring (usually in May). On split treatment plots, manure was applied twice a year with half rates each time i.e. in spring and in fall. 
(b) Forage utilization treatment: Forage utilization treatment was carried from June to August every year, and it consisted of baled dry forage removal (hay treatment) as well as grazing which was done by yearling beef steers (grazed treatment).

Based on above treatments, the study area was divided into six types of plots namely control-hayed, full-hayed, control-grazed, full-grazed, split-hayed and split-grazed in the year 2007 (Coppi, 2012). The grazed plots with control treatment covered an area of 8 ha whereas the grazed plots with single as well as split treatments had an area of 4 ha each. Each hay plot covered an area of 1.2 ha. The size of each plot was so adjusted that 8-10 animals and the standing forage of $1000-1150 \mathrm{~kg}$ dry matter per ha were always maintained. In the case of an excess number of animals and when standing forage became less than $400 \mathrm{~kg} \mathrm{ha}^{-1}$, some animals were removed from the plot. Haying was done once in a year to the respective plots, usually in June when grass was in its early head phonological stage (Coppi, 2012).

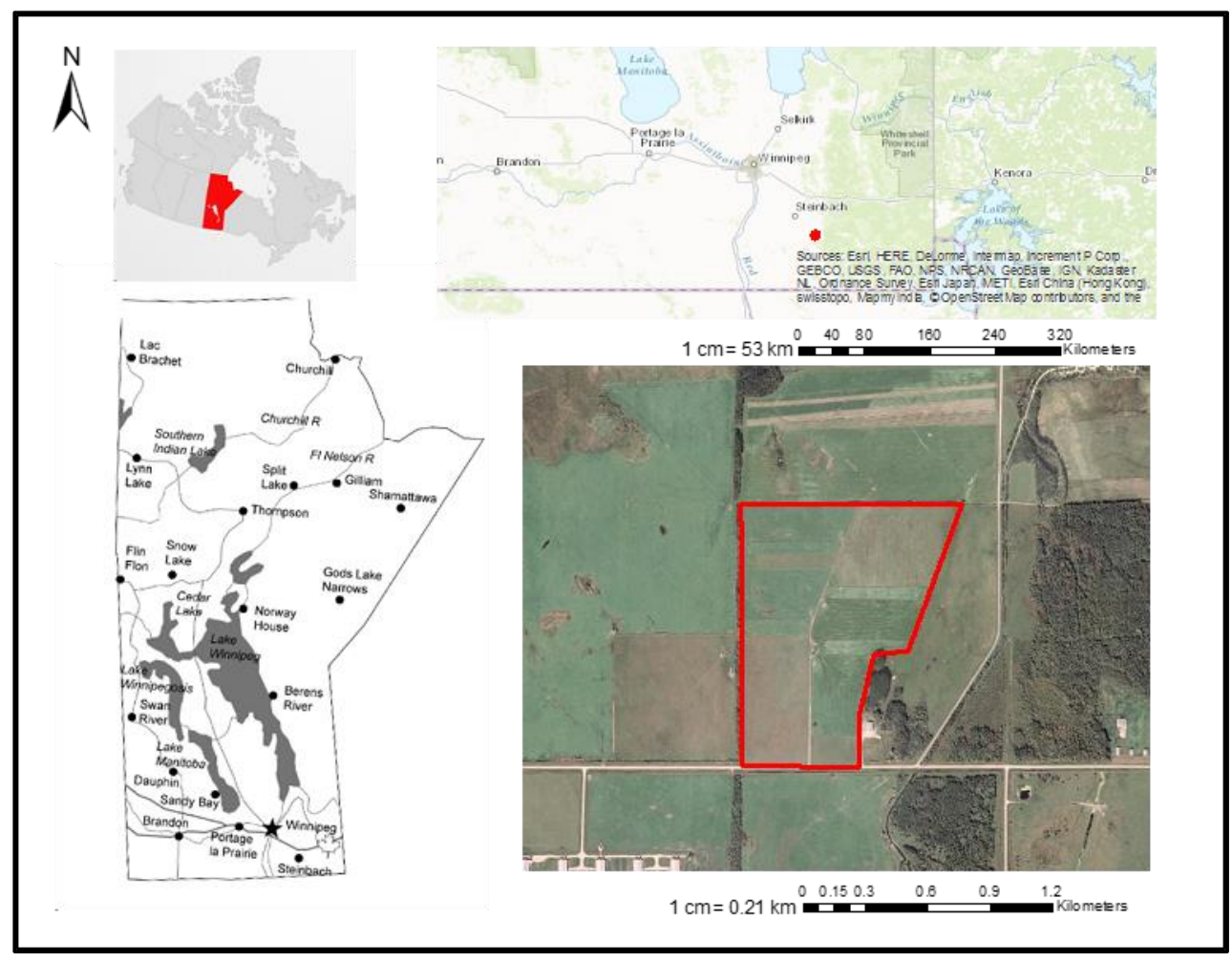

Figure 2: Location of the study site in Manitoba, Canada 


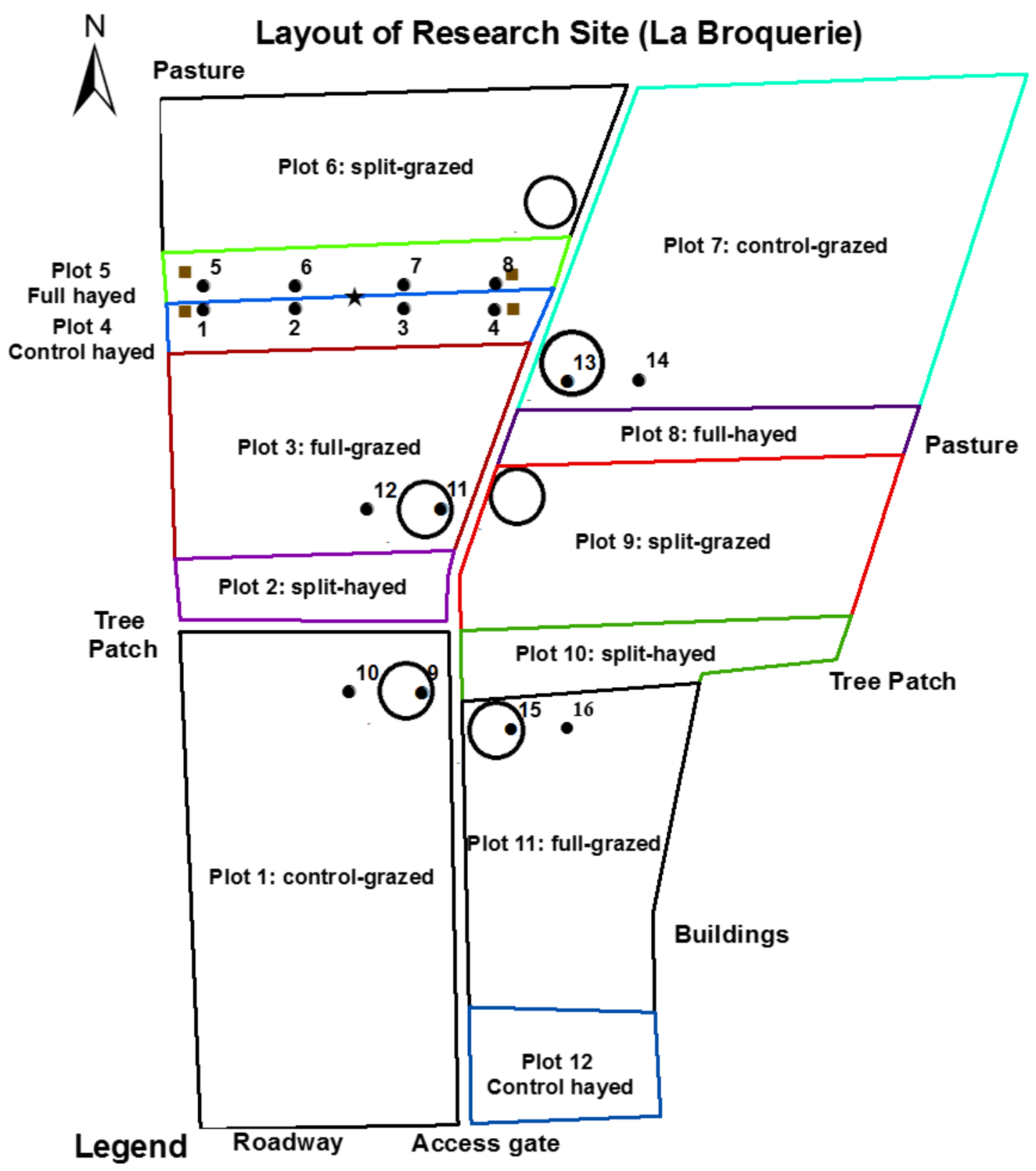

- Soil pits

$\star \quad$ weather station

- Monitoring wells and Sensor Stations (SSs) with themocouple and TDR probes

Bare Earth Areas (BEAs) around waterers

Figure 3: Layout of the research site in La Broquerie, the total size of which is 40 ha, showing the division of site into slurry and forage utilization treatments 


\subsection{Data analysis}

The daily on-site weather conditions for years 2008 and 2009 were monitored using a Campbell Scientific weather station, equipped with a data-logger (CR1000, Campbell Scientific Canada Corp.) (Coppi, 2012). The weather station was installed at the boundary between plot 4 and 5 (Figure 3). It recorded the hourly (averaged to the daily values) meteorological data including precipitation, maximum and minimum air temperatures, solar radiation, relative humidity, wind speed and atmospheric pressure.

The annual rainfall precipitation was measured as $459 \mathrm{~mm}$ and $542 \mathrm{~mm}$ for years 2008 and 2009 respectively (Figure 4). Depth to groundwater was measured at SS-3 (Figure 5) on a daily basis for both years using a pressure transducer with a data logger (Aquistar PT2X with Aqua4Plus Control Software, INW, Kirkland, WA). Heavy precipitation events recorded in the year 2009 led the groundwater table to rise up to the ground surface (Figure 5).

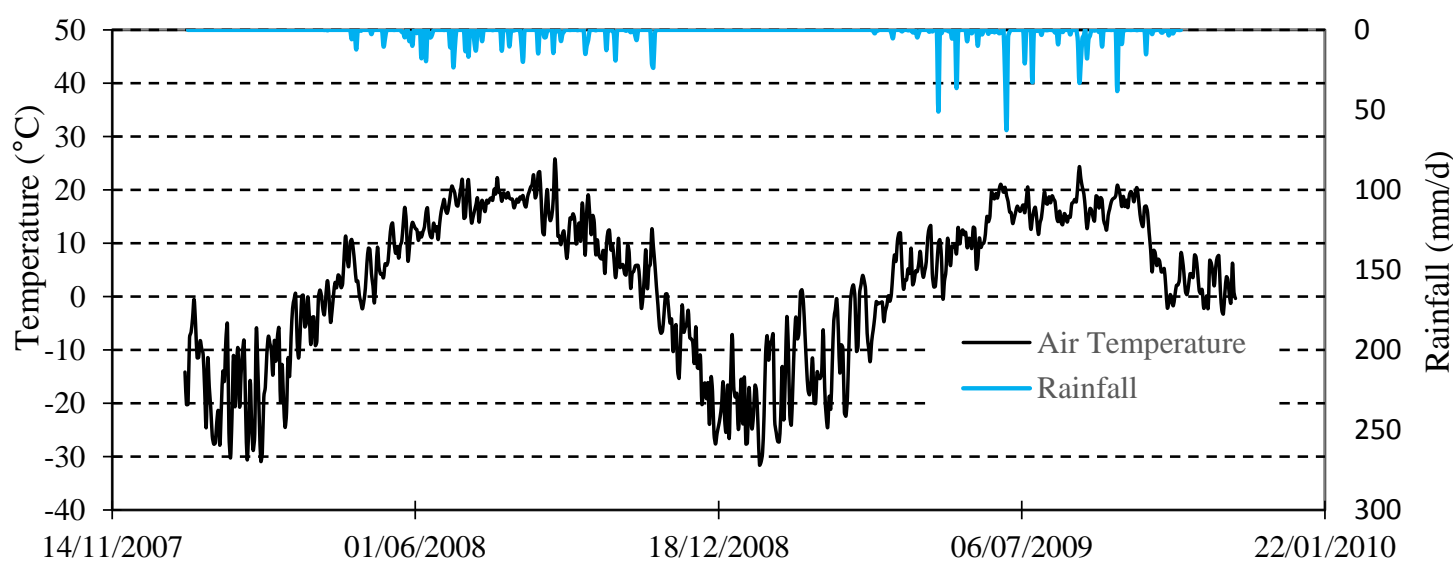

Figure 4: Daily mean observed air temperature and precipitation at Campbell Scientific weather station (Jan 2008 to Oct 2009). Data source (Coppi, 2012) 


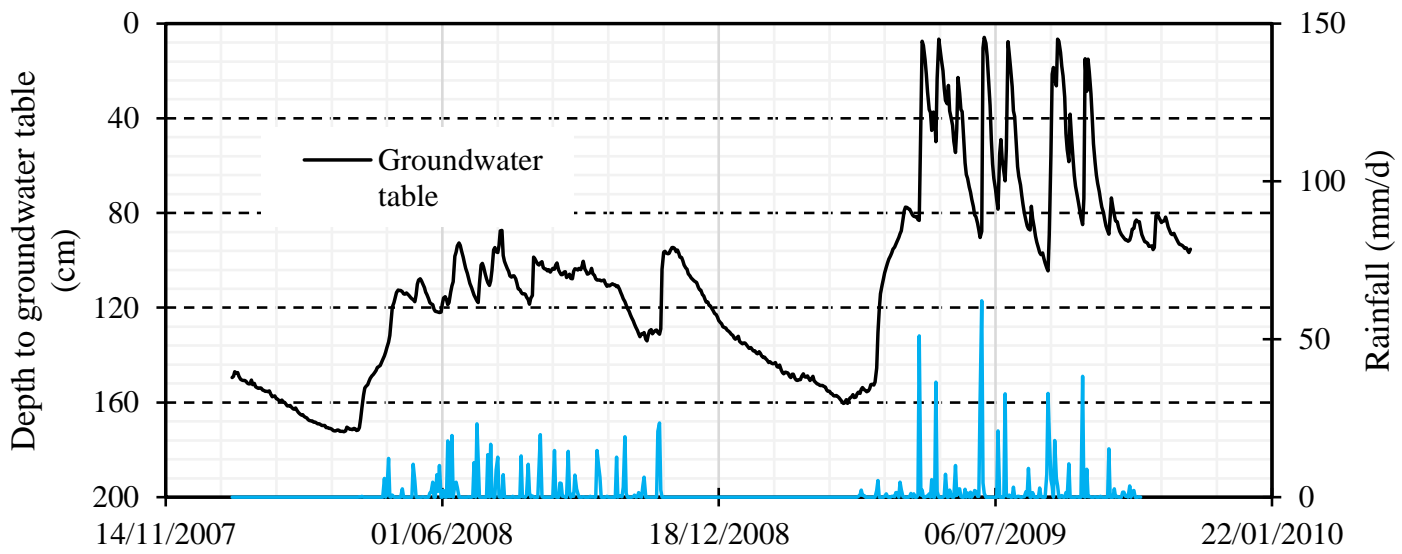

Figure 5: Depth to groundwater table from soil surface measured at SS-3 for the years 2007, 2008 and 2009. Elevation of monitoring wells was $303.52 \mathrm{~m}$ asl. (Data source: Coppi, 2012)

The daily soil moisture content at depths $15,45,75$ and $105 \mathrm{~cm}$ for years 2008 and 2009 was measured using tensiometers and TDR probes at SS-1 to SS-8. Daily soil moisture content observations at SS-3 (depth $15 \mathrm{~cm}$ ) increased after precipitation events (Figure 6). Soil moisture content was recorded to be less than $0.1 \mathrm{~cm}^{3} / \mathrm{cm}^{3}$ during the winter months due to the soil being in a frozen state (Figure 6). TDR probes measured such low values of soil moisture content in winter months due to the fact that dielectric constant of water in the form of ice is very low (about 4) as compared to its liquid form (about 80 at $20^{\circ} \mathrm{C}$ ) (Jones et al., 2002).

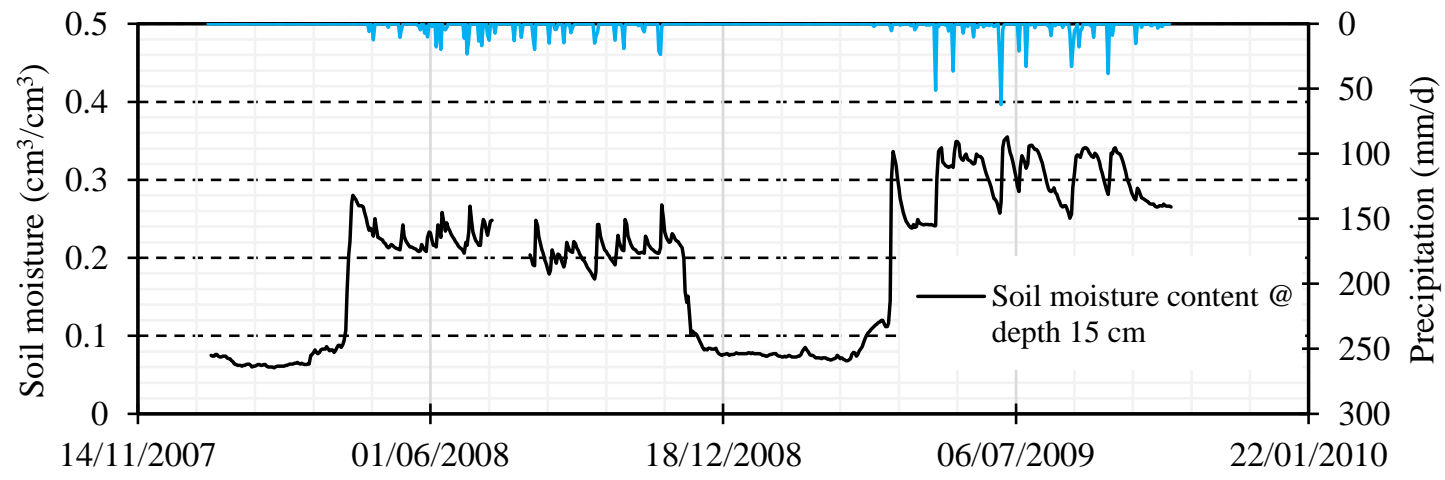

Figure 6: Observed soil moisture content at SS-3 (depth: $15 \mathrm{~cm}$ below soil surface). Data source (Coppi, 2012) 
Surface application of liquid hog manure started in May 2004 at the study site (Coppi, 2012). The rates of application each year were based on the $\mathrm{N}$ requirement of pasture which was 123 kg plant available-N ha ${ }^{-1}$ year $^{-1}$ (Coppi, 2012). From 2004-2006, manure was applied at 142 kg plant available-N ha ${ }^{-1}$ year $^{-1}$ whereas, in 2007, 2008 and 2009, it was applied at 105, 119 and $224 \mathrm{~kg}$ plant available- $\mathrm{N} \mathrm{ha}^{-1}$ year $^{-1}$. In single-treatment plots, manure was applied with full rate during the first week of May whereas, in split-treatment plots, it was applied with the half rate in May and then again with half rate at the beginning of October. Before each application, manure's organic- $\mathrm{N}$ and ammonium contents were measured with a hydrometer and Agros Nova Mk3 manure-N meter respectively. Based on these measurements, plant available-N concentration of manure was estimated as the difference between total and organic-N. At the time of application, it was assumed that $25 \%$ of the nitrogen available in the form of ammonium was volatilized as ammonia under cold and humid weather conditions. (Coppi, 2012). The chemical analysis of the manure samples carried out in a commercial laboratory in Winnipeg (Norwest Laboratory) was used to determine the actual plant available-N (Coppi, 2012). The manure characteristics are given Appendix-A.2.

The source of nutrients in BEAs (Bare Earth Areas) was through the deposition of urine and feces by steers. Williams and Haynes (1990) explained that most of the $\mathrm{N}$ ingested by steers from pasture are not utilised (about 60-99\%) and get excreted with urine and feces. An event of urination can provide highly localised rates of $\mathrm{N}$-application to the soil at anywhere between 500-1000 $\mathrm{kg} \mathrm{N} \mathrm{ha}^{-1}$ even though 20-60\% urea can be lost as ammonia through volatilization (Williams and Haynes, 1990).

The concentration of nitrate in groundwater at SS-1 to SS-16 was dependent on the type of manure-treatment plot and BEAs. Starting from SS-1 to SS-4 located in the control-hayed plot (plot 4) and SS-5 to SS-8 located in the full-hayed plot (plot 5), the observed nitrate concentrations in groundwater were always below $1 \mathrm{mg} \mathrm{NO}_{3}-\mathrm{N} \mathrm{L}^{-1}$ in 2008 and 2009 (Figure 
7 and Figure 8). Therefore, the average concentration of these SS's was taken and used as observed data for numerical modeling.

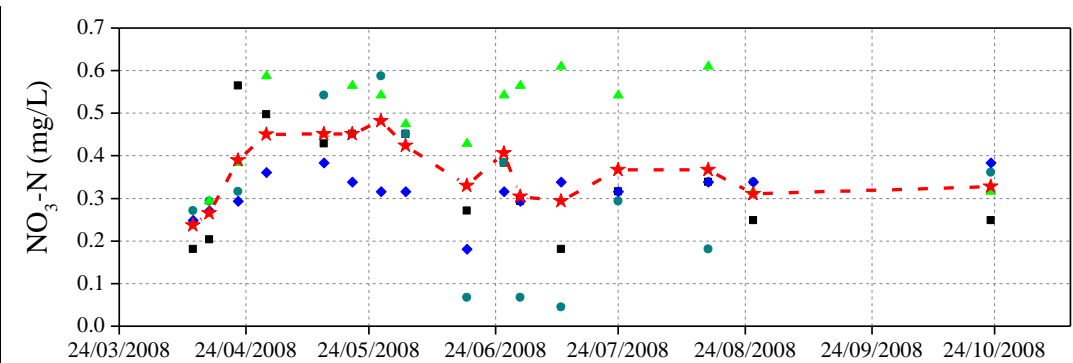

(a)

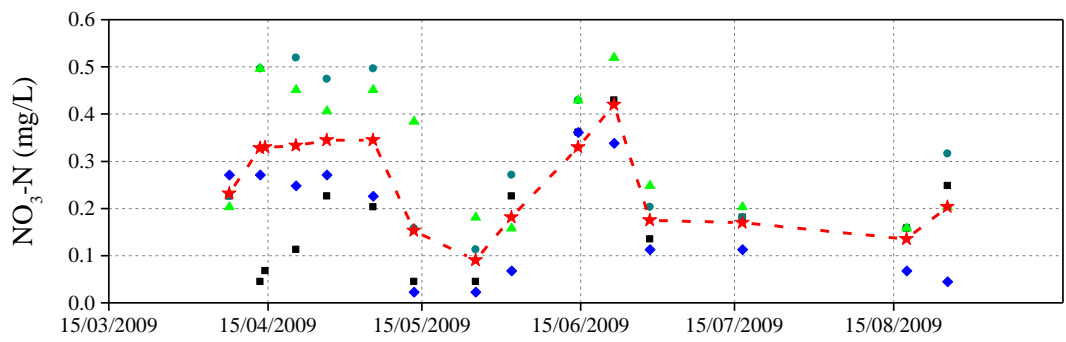

- Observed nitrate concentration at SS-

- Observed nitrate concentration at SS-2

Observed nitrate concentration at SS-3

(b) control-hayed type plot

- Observed nitrate concentration at SS-4

- $\star$ - Average concentration

Figure 7: Observed nitrate groundwater concentrations at SS-1 to SS-4 and their average for the years (a) 2008 and (b) 2009

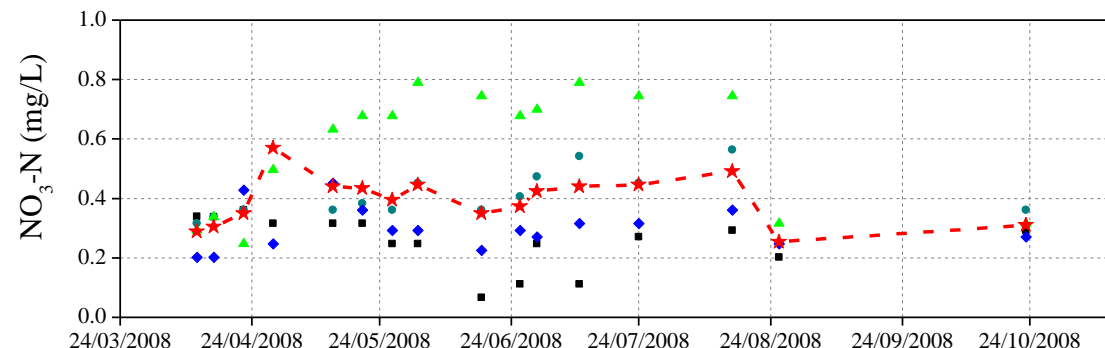

(a)

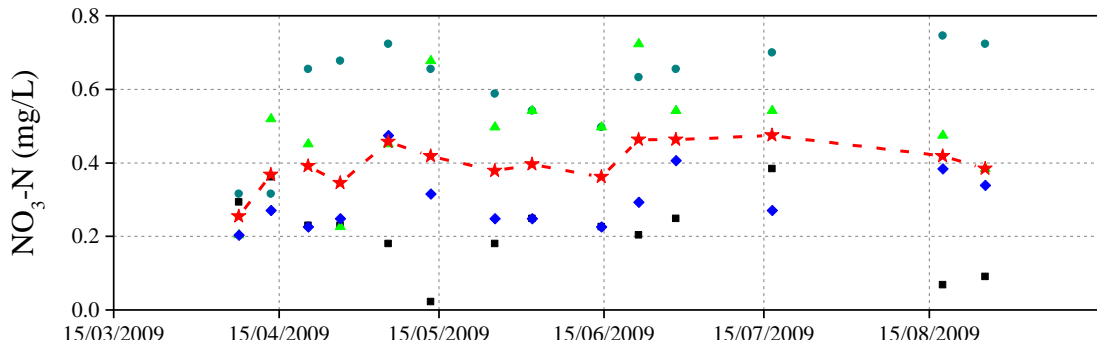

- Observed nitrate concentration at SS-5

Observed nitrate concentration at SS-6

Observed nitrate concentration at SS-7

(b)

concentration at SS-8

$\star$ - Average concentration

Figure 8: Observed nitrate groundwater concentrations at SS-5 to SS-8 and their average for the years (a) 2008 and (b) 2009 
For SS-12 \& SS-16, located in full-grazed plots, the concentration of nitrate in groundwater was between 2-8 mg NO $3-\mathrm{N} \mathrm{L}^{-1}$ for most of the time in both years of study (Figure 9). The increased concentrations at these SSs as compared to control-hayed, full-hayed and controlgrazed plots were mainly due to the application of manure at full rates in early spring and less removal of nitrate due to the utilization of forage by animal grazing (Coppi, 2012). Forage utilization treatment by haying removed a larger amount of nitrate from the soil as compared to that by animal grazing. This resulted in a lesser concentration of nitrate in groundwater at plots where haying was adopted (Coppi, 2012) (Figure 7, Figure 8 and Figure 9).

SS-9 \& SS-13 were located in BEAs of control-grazed plots whereas the SS-11 \& SS-15 were located in the BEAs of full-grazed plots. The nitrate concentration in groundwater at all of these SSs was significantly greater than in other parts of the study area and the drinking water threshold of $10 \mathrm{mg} \mathrm{NO}_{3}-\mathrm{N} \mathrm{L}^{-1}$ (Figure 10). As mentioned before, the BEAs of controlgrazed plots received lesser amounts of nitrogen via animal excretes, hence the concentration of nitrate in groundwater at these spots was lower than the BEAs of full-grazed plots (Figure 10). 


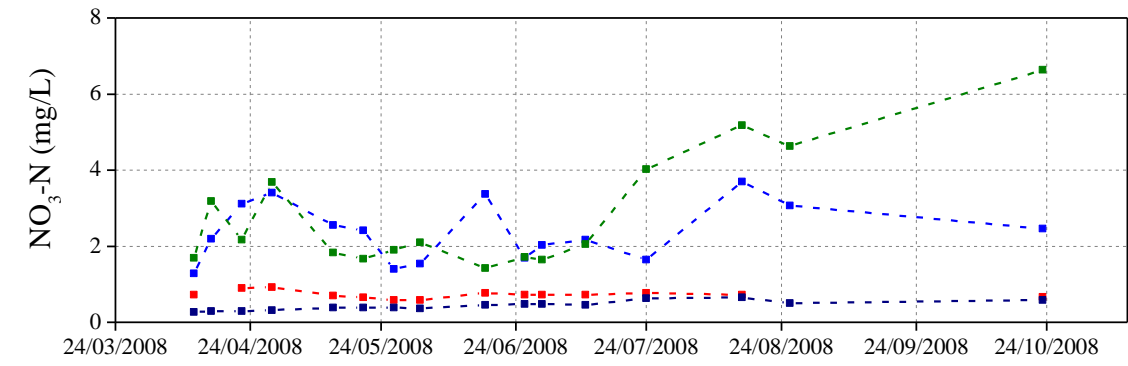

(a)

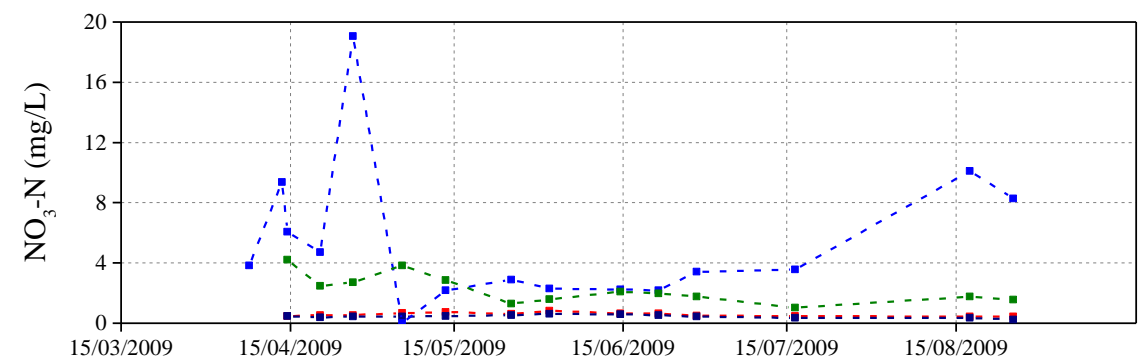

$\cdot-\cdot$ Observed nitrate concentration at SS-10

- Observed nitrate concentration at SS-14

(b)

- Observed nitrate concentration at SS-12

- - Observed nitrate concentration at SS-16

full-grazed type plot

Figure 9: Observed nitrate groundwater concentrations at SS-10, SS-12, SS-14 \& SS-16 for the years (a) 2008 and (b) 2009

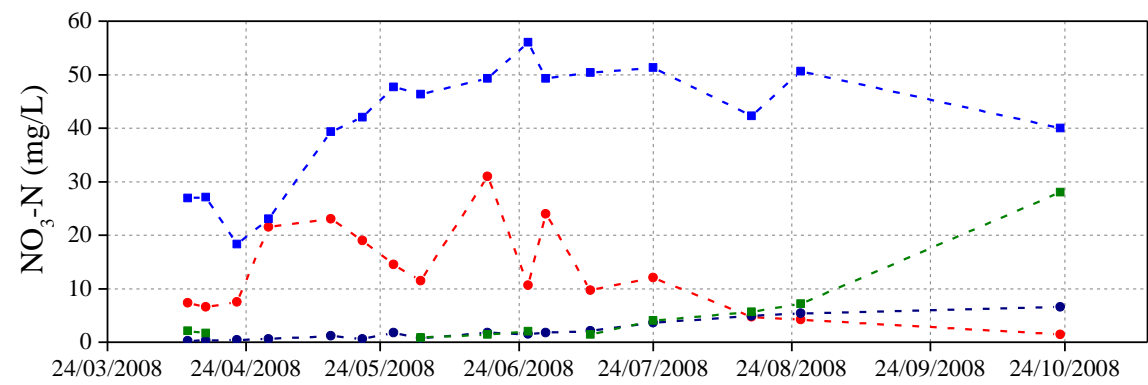

(a)

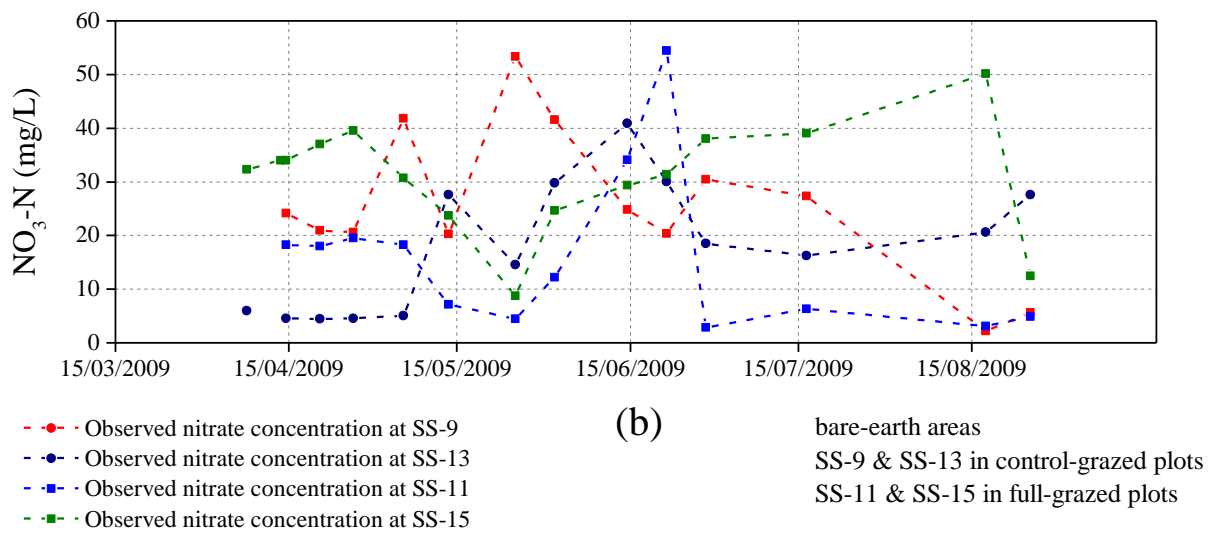

Figure 10: Observed nitrate groundwater concentrations for SS-9, SS-11, SS-13 \& SS-15 for the years (a) 2008 and (b) 2009 


\subsection{Vadose zone modeling}

HYDRUS-1D version 4.16 (Simunek et al., 2008) is a physically based numerical modeling program which allows simulating one-dimensional (1D) flow of water, heat, and solute in the variably saturated zone. This tool was used in the present study to estimate recharge and leaching of nitrate from the surface application of liquid hog manure.

Water flow: The variably saturated water flow was simulated in HYDRUS-1D using Richards equation (Richards, 1931) :

$$
\frac{\partial \theta}{\partial \mathrm{t}}=\frac{\partial}{\partial \mathrm{z}}\left[\mathrm{K}(\psi)\left(\frac{\partial \psi}{\partial \mathrm{z}}\right)-\mathrm{S}\right]
$$

where $\psi[\mathrm{L}]$ represents pressure head, $\theta\left[\mathrm{L}^{3} \mathrm{~L}^{-3}\right]$ is the volumetric water content, $\mathrm{t}[\mathrm{T}]$ represents time, $\mathrm{z}[\mathrm{L}]$ is the elevation, $\mathrm{S}\left[\mathrm{L}^{3} \mathrm{~L}^{-3} \mathrm{~T}^{-1}\right]$ is the sink term and unsaturated hydraulic conductivity is represented by $\mathrm{K}(\psi)\left[\mathrm{LT}^{-1}\right]$ which is a function of $\psi$ and saturated hydraulic conductivity $\mathrm{K}_{\mathrm{s}}\left[\mathrm{LT}^{-1}\right]$. The hydraulic conductivity, $\mathrm{K}(\psi)$, and soil water retention, $\theta(\psi)$ functions were estimated based on van Genuchten-Mualem (VGM) model (Mualem, 1976; van Genuchten, 1980):

$\theta(\psi)= \begin{cases}\theta_{\mathrm{r}}+\frac{\theta_{\mathrm{s}}-\theta_{\mathrm{r}}}{\left[1+\left|\alpha \mathrm{h}^{\mathrm{n}}\right|\right]^{\mathrm{m}}} & \psi<0 \\ \theta_{\mathrm{s}} & \psi \geq 0\end{cases}$

$\mathrm{K}(\psi)=\mathrm{K}_{\mathrm{s}} \mathrm{S}_{\mathrm{e}}\left[1-\left(1-\mathrm{S}_{\mathrm{e}}^{\frac{1}{\mathrm{~m}}}\right)^{\mathrm{m}}\right]^{2}$

where $\theta_{\mathrm{s}}\left[\mathrm{L}^{3} \mathrm{~L}^{-3}\right]$ is the saturated water content, $\theta_{\mathrm{r}}\left[\mathrm{L}^{3} \mathrm{~L}^{-3}\right]$ is residual water content and $\alpha\left[\mathrm{L}^{-1}\right]$, $\mathrm{n}[-]$ and $\mathrm{m}[-]$ are the shape empirical parameters, $\mathrm{K}_{\mathrm{s}}\left[\mathrm{LT}^{-1}\right]$ represents saturated hydraulic conductivity, and $\mathrm{S}_{\mathrm{e}}[-]$ is the effective saturation.

$$
\mathrm{S}_{\mathrm{e}}=\frac{\theta-\theta_{\mathrm{r}}}{\theta_{\mathrm{s}}-\theta_{\mathrm{r}}}
$$


The estimation or the actual measurement of the VGM parameters $\left(\alpha, n, m, \theta_{\mathrm{s}}, \theta_{\mathrm{r}}\right.$ and $\left.\mathrm{K}_{\mathrm{s}}\right)$ is complex, time-consuming and expensive. Hence, these parameters were estimated using a built-in function ROSETTA (Schaap et al., 2001b) which makes use of soil textures classified on the basis of USDA system.

Root water uptake: The Feddes-type function (Feddes et al., 1978) representing evapotranspiration effect to the water distribution was used to estimate the root water uptake flux. The default parameterization of 'Pasture' integrated into HYDRUS-1D representing the pasture crop type was used (parameters $h_{o}, h_{o p t}, h_{2}$, and $h_{3}$ explained in next paragraph). The sink/source term mentioned in equation 2 was determined as per equation 6 below:

$S(h)=\alpha(h) S_{p}$

where $S(h)\left[\mathrm{T}^{-1}\right]$ represents the rate of root water uptake per unit volume of soil, $\alpha(\mathrm{h})[-]$ and $\mathrm{S}_{\mathrm{p}}\left[\mathrm{T}^{-1}\right]$ are root water coefficient and maximum or potential root water uptake rate respectively (Feddes et al., 1978). In equation 6, it was assumed that water uptake for soil being close to saturation is equal to zero. The 'close to saturation' condition is considered to be wetter than an arbitrary "anaerobiosis point", $h_{0}$. For pressure head less than the crop's wilting point $\left(h_{3}\right)$, root water uptake is considered equal to zero. The optimal root water uptake is considered between the pressure head $h_{2}$ and $h_{\text {opt. }}$ For pressure head between $h_{2}$ and $h_{3}$ and between $h_{o}$ and $h_{o p t}$, water uptake increases and decreases linearly with pressure head respectively. For pasture crop, $\mathrm{h}_{\mathrm{o}}, \mathrm{h}_{\mathrm{opt}}, \mathrm{h}_{2}$, and $\mathrm{h}_{3}$ values are listed in table 3 .

Evapotranspiration: The estimation of potential evapotranspiration was done using the Penman-Monteith equation (equation 7) (Allen et al., 1998) for which the input data such as wind speed, daily average temperature, solar radiation, relative humidity were used. 


$$
\lambda \mathrm{ET}=\frac{\Delta\left(R_{n}-G\right)+\rho_{a} C_{p} \frac{e_{s}-e_{a}}{r_{a}}}{\Delta+\gamma\left(1+\frac{r_{s}}{r_{a}}\right)}
$$

where $R_{n}\left[M T^{-3}\right]$ represents the net radiation, soil heat flux is represented by $G$, $\left(e_{s}-e_{a}\right)\left[M^{-}\right.$ $\left.{ }^{1} \mathrm{~T}^{-2}\right]$ is the vapour pressure deficit of the air, $\rho_{\mathrm{a}}\left[\mathrm{ML}^{-3}\right]$ is the average air density at any constant pressure, $\mathrm{C}_{\mathrm{p}}\left[\mathrm{L}^{2} \mathrm{~T}^{-2} \mathrm{~K}^{-1}\right]$ represents the specific heat of the air, the slope of saturation vapour pressure and temperature relationship is represented by $\Delta\left[\mathrm{ML}^{-1} \mathrm{~T}^{-2} \mathrm{~K}^{-1}\right], \gamma\left[\mathrm{ML}^{-1} \mathrm{~T}^{-2} \mathrm{~K}^{-}\right.$ $\left.{ }^{1}\right]$ is the psychrometric constant, and $r_{s}$ and $r_{a}\left[\mathrm{TL}^{-1}\right]$ are the (bulk) surface and aerodynamic resistances.

Soil freezing and thawing: The standard code of HYDRUS-1D version 4.16 (Simunek et al., 2008) was used in this study. The freezing and thawing of water inside the soil pores was not simulated with the standard code. However, a 'snow hydrology' function was used which assumed that precipitation was in the form of snow when the air temperature was below $2^{\circ} \mathrm{C}$ and in the form of rain when the air temperature was above $2{ }^{\circ} \mathrm{C}$ and a linear transition occurred between these two limiting temperatures (Jarvis, 1989).

Snow water equivalent (SWE): HYDRUS-1D allows inputting an initial layer of snow on the ground that melts proportionally to the air temperature. Snow water equivalent can be defined as the amount of liquid water (in $\mathrm{cm}$ ) in the snowpack if it is allowed to melt completely. The SWE for La Broquerie was not available for both years of study. However, Government of Manitoba (2008) reported the SWE range of $25-50 \mathrm{~mm}$ in 2008 and 2009 for most areas of southern Manitoba and. SWE of $50 \mathrm{~mm}$ was considered in this study for both years.

Solute transport: In a variably saturated rigid porous medium, the transport of solute in onedimensional advective-dispersive manner is governed by the partial differential equation: 
$\frac{\partial \theta c_{k}}{\partial t}+\rho \frac{\partial \overline{c_{k}}}{\partial t}=\frac{\partial\left(\theta D \frac{\partial c_{k}}{\partial z}\right)}{\partial z}-\frac{\partial q c_{k}}{\partial z}+\emptyset_{k}-S c_{r}$

where $\theta\left[\mathrm{L}^{3} \mathrm{~L}^{-3}\right]$ signifies the volumetric water content, $c_{k}\left[\mathrm{ML}^{-3}\right]$ and $\overline{c_{k}}\left[\mathrm{MM}^{-1}\right]$ are concentration of solute in liquid and solid phase respectively, $\rho\left[\mathrm{ML}^{-3}\right]$ signifies the bulk density of soil, $q\left[\mathrm{LT}^{-1}\right]$ is the volumetric flux density, $\mathrm{D}\left[\mathrm{L}^{2} \mathrm{~T}^{-1}\right]$ represents the hydrodynamic dispersion coefficient, $\varnothing\left[\mathrm{ML}^{-3} \mathrm{~T}^{-1}\right]$ represents the chemical reaction of solutes involved in a sequential decay chain of first order, for example, nitrification of species of nitrogen, $S\left[\mathrm{~T}^{-1}\right]$ is the sink term which represents the root water uptake in water flow equation, $c_{r}\left[\mathrm{ML}^{-3}\right]$ represent the sink term concentration, the chemical species (e.g $\mathrm{NO}_{3}{ }^{-}, \mathrm{NH}_{4}{ }^{+}$and other major ions) are represented by the subscript $k$. $S c_{\mathrm{r}}$ represents the passive root nutrient uptake (Liu et al., 2013b; Simunek et al., 2008). The nitrogen uptake by roots was simply estimated by multiplying root water uptake and soil mineral nitrogen concentration.

Nitrification of species of $\mathrm{NH}_{4}+$ to the species of $\mathrm{NO}_{3}$ - is represented by the parameter $\emptyset$ in equation $9 \mathrm{a}$ and $9 \mathrm{~b}$ and is obtained as follows for $\mathrm{NH}_{4}+$ and $\mathrm{NO}_{3-}$ (Liu et al., 2013b)

$$
\begin{aligned}
& \emptyset_{\mathrm{NH}_{4}^{+}}=-\mu_{w, \mathrm{NH}_{4}^{+}} \theta c_{\mathrm{NH}_{4}^{+}}-\mu_{s, \mathrm{NH}_{4}^{+}} \theta \bar{c}_{\mathrm{NH}_{4}^{+}} \\
& \emptyset_{\mathrm{NO}_{3}^{-}}=\mu_{w, \mathrm{NH}_{4}^{+}} \theta c_{\mathrm{NH}_{4}^{+}}+\mu_{s, \mathrm{NH}_{4}^{+}} \theta \bar{c}_{\mathrm{NH}_{4}^{+}}
\end{aligned}
$$

where $\mu_{w}\left[\mathrm{~T}^{-1}\right]$ and $\mu_{s}{ }^{\left[\mathrm{T}^{-1}\right]}$ represent the rate (first order) constant for the solutes in liquid as well as solid phase respectively.

Assumptions: Nitrification of ammonium to nitrate was considered in the modeling process with an assumption that ammonium was directly transformed to nitrate instead of its intermediate conversion to nitrite. Nitrification from nitrite to nitrate is a very fast process and hence neglected (Hanson et al., 2006). Ammonium was assumed to adsorb on negatively charged soil particles based on linear adsorption isotherm also known as Henry's adsorption isotherm. Denitrification of $\mathrm{NO}_{3}$ (nitrate) to $\mathrm{N}_{2}$ (nitrogen gas) or $\mathrm{N}_{2} \mathrm{O}$ (nitrous oxide) was not 
considered since it seldom occurs in unsaturated soil conditions. $25 \%$ of ammonium present in the slurry was assumed to be volatilized as ammonia during its surface application under the cold, humid conditions (Coppi, 2012). Surface runoff was neglected since it was unlikely to happen in coarse-textured soils with low soil water retention and flat terrains.

Initial and boundary conditions: The initial conditions for flow and solute transport model were assigned according to the observed soil moisture content, nitrate, and ammonium concentrations in the soil water at different depths.

"Atmospheric BC with surface runoff" was used as upper BC (Boundary Condition) since the meteorological (external) conditions controlled the potential water flux across the upper boundary. Few examples of external conditions controlling potential water flux could be the ponding of the surface due to rapid warming and frequent precipitation, large variation in temperature with the change of season and the dynamic moisture conditions of the soil. There was a significant seasonal groundwater fluctuation at the study site; hence "variable pressure head" was employed as the lower boundary condition which estimated the flux depending on the position of the groundwater table.

For the upper boundary, Cauchy (third-type) boundary condition was used to describe the concentration flux at the soil surface (equation 10) whereas a free drainage boundary condition was used as a bottom boundary condition to allow free drainage of solute flux in the soil profile.

$-\theta D \frac{\partial c_{k}}{\partial z}+q c_{k}=q_{0} c_{k 0}$

where $q_{o}$ and $c_{o}$ represent the water flux and concentration of the infiltrating fluid $\left[\mathrm{ML}^{-3}\right]$. 


\subsection{Model calibration}

Model calibration can be defined as the process of manipulating the model input parameters such as water flow parameters, solute transport parameters, initial conditions or boundary conditions within a reasonable range such that the model becomes tuned for a particular problem and yields results with a close match to the observations e.g. soil moisture content, pressure heads, etc. (Šimůnek et al., 2012). The prediction of VGM parameters in HYDRUS1D was made using ROSETTA. Since ROSETTA was developed using soil samples from the USA and European countries, the program could generate an inaccurate prediction of VGM parameters if the soil samples were taken from other places such as Canada (Simunek et al., 2008). Hence, to provide an authentic description of the soil properties, 'inverse modeling' was implemented which used a Marquardt-Levenberg (Marquardt, 1963) type of technique based on a weighted least-squares approach. It used the observed and/or solute transport data for the inverse estimation of soil hydraulic, solute and/or heat transport parameters (Šimůnek et al., 2012). The VGM parameters $\theta_{s}$ (saturated water content), $\theta_{r}$ (residual water content), $\alpha, n$ and $m$ (shape empirical parameters) and $\mathrm{K}_{\mathrm{s}}$ (saturated hydraulic conductivity) were initially estimated using ROSETTA (table 2). These parameters were then calibrated based on observed soil moisture data at different depths.

\subsection{Model performance}

Model calibration and performance were evaluated by comparing the observed and simulated soil moisture and groundwater nitrate concentration data for different time periods using various quantitative measures of uncertainty, namely, root mean square error (RMSE), NashSutcliffe efficiency (NSE) (Nash and Sutcliffe, 1970) and mean error (ME). A general assumption behind these model evaluation criteria is that the simulated and observed dataset are continuous such that the data values are not restricted to some particular values. Although 
the observed data are not contentious since they are based on hand sampling with an interval of two weeks (Coppi, 2012). Thus, they have equal intervals and are handled as contentious data here. Thus, the three quantitative measures are used in this research.

$\mathrm{RMSE}=\sqrt{\frac{1}{n} \sum_{i=1}^{n}\left(M_{i}-S_{i}\right)^{2}}$

where $n$ is the number of simulated and observed data set to be compared, $M_{i}$ and $S_{i}$ are the observed and simulated data set points. For a perfect match between the observed and simulated dataset, RMSE should be 0 .

$\mathrm{NSE}=1-\frac{\sum_{i=1}^{n}\left(M_{i}-S_{i}\right)^{2}}{\sum_{i=1}^{n}\left(M_{i}-\bar{M}\right)^{2}}$

where $\bar{M}$ represents the mean of observed dataset points.

$\mathrm{ME}=\frac{1}{n} \sum_{i=1}^{n}\left(M_{i}-S_{i}\right)$

In addition to the above measures of uncertainty, the model performance for this study was also evaluated by the coefficient of determination, $\mathrm{R}$, which is defined as the square of the correlation coefficient, r:

$R=r^{2}=\left(\frac{\sum_{i=1}^{n}\left(M_{i}-\bar{M}\right)\left(S_{i}-\bar{S}\right)}{\sqrt{\sum_{i=1}^{n}\left(M_{i}-\bar{M}\right)} \sqrt{\sum_{i=1}^{n}\left(S_{i}-\bar{S}\right)}}\right)^{2}$

where $\bar{M}$ and $\bar{S}$ are the mean values of observed and simulated date set respectively. The coefficient of correlation lies between 0 and 1 . A value of 0 indicates no correlation between observations and simulations where as a value of 1 implies a strong correlation and a perfect fit between the two datasets. 


\subsection{Sensitivity analysis}

A sensitivity analysis represents how different sources of uncertainty in the input parameter could be apportioned such that their effect can be quantified on the model output, and to screen the sensitive parameters for calibration.

Robustness is used in this research not by its original means but by the definition that the model was considered to be robust if the method chosen provided the results which were reliable and were low-sensitive $(<10 \%)$ to the changes in input parameters. This definition was also used by Holländer et al. (2016) where robustness was defined as the ability of their recharge estimation method to provide a reliable recharge estimate although most input data were derived from different degrees of uncertainty.

The fundamental targets, chosen for sensitivity analysis were soil moisture and nitrate leaching fluxes since a recent study by Holländer et al. (2016) showed that the estimated groundwater recharge was more sensitive to alterations in soil moisture values than to the soil temperature. Since the nitrate leaching fluxes are highly dependent on recharge, their sensitivity to model parameters was also analysed. The parameters $n, \alpha$, and $\mathrm{K}_{\mathrm{s}}$ were varied to determine their impact on the simulated soil moisture, recharge and nitrate leaching. The vegetation parameters, as shown by Liu et al. (2013a) had a minimal impact on groundwater recharge estimates than changes accounting to the VGM parameters. Therefore, vegetation parameters were not considered in the sensitivity analysis of recharge.

One of the most common and simplest approaches to carrying out sensitivity analysis is changing one factor at a time to see the effect the output (Czitrom, 1999). While changing one parameter at a time, all other parameters are kept constant. The feasibility and applicability of this method have been testified in a recent study conducted by Oostrom et al. (2013) who evaluated the sensitivity of the variant cross-correlation parameters. Therefore, 
the calibrated recharge was considered as the baseline for the sensitivity analysis while changing $\alpha$ and $n$ by $\pm 5 \%, \pm 10 \%$ and $\pm 20 \%$ at each time. Ks was changed at a larger scale $\left(\mathrm{Ks} * 2, \mathrm{Ks} / 2, \mathrm{Ks}^{*} 4, \mathrm{Ks} / 4\right)$ to account for soil heterogeneity and thus its impact on recharge and nitrate leaching.

\subsection{Regionalisation of point estimates}

The leaching flux of nitrate at 16 SSs was regionalised for the entire study site (40 ha) using ArcGIS 10.2 built-in function 'Cokriging' (ESRI, 2014). Kriging makes use of only one data type at the target location to map the surfaces. Therefore, the existing spatial correlations between secondary data points and primary attribute are not taken into account using kriging (Journel, 1989). Cokriging, being an extension of Ordinary Kriging can potentially manage the estimation process from several data types (e.g. manure application and leaching flux) to improve the performance of regionalisation. Hence, it was considered as a potential method in the La Broquerie case. The Cokriging equation can be expressed as following:

$u_{0}=\sum_{i=1}^{n} a_{i} u_{i}+\sum_{j=1}^{m} b_{j} v_{j}$

where $u_{\mathrm{o}}$ is the estimate at the grid node or at location $0 ; u_{i}$ is the primary data at $n$ locations nearby, $v_{j}$ is secondary data at $\mathrm{m}$ locations, $a_{i}$ and $b_{j}$ are the undetermined weights assigned to $u_{i}$ and $v_{\mathrm{j}}$ and varies between 0 and 1 . Unbiasedness in the estimates is assured if the weights of primary data sum to 1 and that of secondary data sum to 0 (Yalçin, 2005):

$\sum_{i=1}^{n} a_{i}=1$ and $\sum_{j=1}^{m} b_{j}=0$

The additional cross-correlation between various parameters makes Cokriging to perform better than Kriging (Ahmadi and Sedghamiz, 2008). The primary variable of interest was nitrate flux that leached below the root zone. Cross-correlations between nitrate flux and 
manure application were considered to improve the prediction of resulting map. Since the soil type at study area was mainly loamy to gravelly sand which was considered to be highly uniform and moreover, the distribution difference of precipitation at study area was ignored due to the small size of the study area (40 ha).

Inverse Distance Weighing (IDW) is a deterministic interpolation method by which weights are assigned to the points where interpolation of any variable has to be done based on the known value of that variable at neighboring point locations in the study area. The value of weights was calculated as the inverse of the distance between the point where interpolation has to be done and the neighbouring points of known value of a variable of interest.

$u(x)=\frac{\sum_{i=1}^{N} w_{i}(x) u_{i}}{\sum_{i=1}^{N} w_{i}(x)}$

$w_{i}=\frac{1}{d\left(x, x_{i}\right)^{p}}$

where $u$ is the variable to be interpolated using a known point $x, i$ represents the set of points where interpolation has to be done and their corresponding weights represented by $w, d$ represents the distance between a known point and the point where value of variable is unknown, $p$ represents a power parameter (Bartier and Keller, 1996).

Natural Neighbor (NN) interpolation method is also based on weights assigned to an unknown point, similar to IDW. However, these weights are assigned using closest neighboring points.

The interpolated map using estimated nitrate leaching fluxes at 16 SSs did not extend through the entire study area but only a limited boundary of those 16 SSs. To overcome this problem, 15 virtual SSs were assumed (17-31) through the boundary of the study area (in different plots) such that a resulting interpolated map that covers the entire study area could be 
obtained. It was assumed that nitrate leaching fluxes for similar plots were equal and hence the virtual SSs were assigned equal flux values corresponding to one of the 16 SSs depending on the plot type.

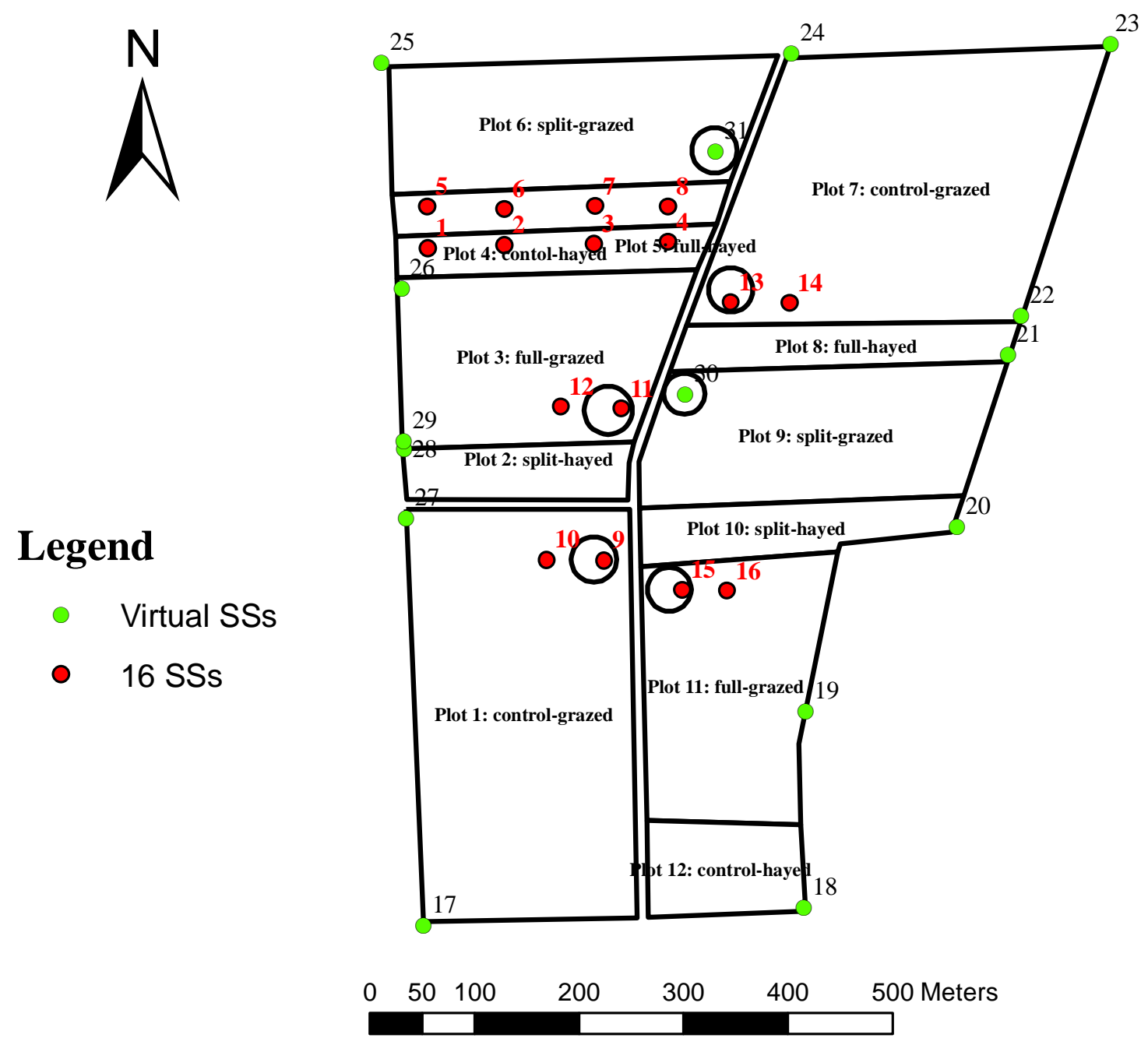

Figure 11: Data points used (16 SSs and additional virtual SSs) to generate an interpolated map that represents the nitrate leaching flux for the entire study area 


\section{Chapter 4: Parameterization}

Various types of soil hydraulic, solute as well as heat transport parameters are required as input for variably-saturated models. The unsaturated soil hydraulic properties impact the soil moisture characteristic curve as well as the hydraulic conductivity function. A soil moisture characteristics curve, also known as soil water retention curve can be defined as a relationship between soil water content, $\theta$ and matric suction, $\psi$ (Fredlund and Xing, 1994). The unsaturated hydraulic conductivity $K(\theta)$ is dependent on the water content of the soil system which reduces with increasing matric suction $(\psi)$ in soil and is required for modeling water and solute transport in the soil. However, its measurement in the field as well as in laboratory is difficult, expensive and time-consuming. Therefore various analytical models are implemented in HYDRUS-1D which can estimate the unsaturated hydraulic properties (Simunek et al., 2008) such as Brooks and Corey (1964), van Genuchten (1980), Vogel and Cislerova (1988), Kosugi (1996) and Durner (1994). The van-Genuchten-Mualem model was explained in section 3.4 which makes the use of parameters $\theta_{s}$ (saturated water content), $\theta_{r}$ (residual water content), $\alpha, n$ and $m$ (shape empirical parameters) and $\mathrm{K}_{\mathrm{s}}$ (saturated hydraulic conductivity).

Soil hydraulic parameters: The VGM parameters estimated using ROSETTA (Schaap et al., 2001a) are listed in table 2 for all the SSs.

Table 2: VGM parameters estimated by PTF

\begin{tabular}{|c|c|c|c|c|c|c|}
\hline $\begin{array}{c}\text { Soil Sampling } \\
\text { location }\end{array}$ & $\begin{array}{c}\text { Depth } \\
{[\mathrm{cm}]}\end{array}$ & $\begin{array}{c}\theta \mathbf{r} \\
{\left[\mathrm{cm}^{3} / \mathrm{cm}^{3}\right]}\end{array}$ & $\begin{array}{c}\theta_{\mathrm{s}} \\
{\left[\mathrm{cm}^{3} / \mathrm{cm}^{3}\right]}\end{array}$ & $\alpha[1 / \mathrm{cm}]$ & $n[-]$ & $\mathrm{K}_{\mathrm{s}}[\mathrm{cm} / \mathrm{d}]$ \\
\hline \multirow{4}{*}{ SS-1 } & 0 to 30 & 0.04 & 0.33 & 0.03 & 1.82 & 81.0 \\
\hline & 30 to 60 & 0.03 & 0.25 & 0.04 & 1.91 & 30.9 \\
\hline & 60 to 90 & 0.04 & 0.26 & 0.03 & 2.85 & 179.5 \\
\hline & 90 to 200 & 0.04 & 0.26 & 0.03 & 2.85 & 167.4 \\
\hline & 0 to 30 & 0.04 & 0.33 & 0.03 & 1.82 & 81.0 \\
\hline SS-2 & 30 to 60 & 0.03 & 0.25 & 0.04 & 1.91 & 30.9 \\
\hline
\end{tabular}




\begin{tabular}{|c|c|c|c|c|c|c|}
\hline & 60 to 90 & 0.04 & 0.26 & 0.03 & 2.85 & 179.5 \\
\hline & 90 to 200 & 0.04 & 0.26 & 0.03 & 2.85 & 167.4 \\
\hline \multirow{4}{*}{ SS-3 } & 0 to 30 & 0.04 & 0.33 & 0.03 & 1.82 & 81.0 \\
\hline & 30 to 60 & 0.03 & 0.25 & 0.04 & 1.91 & 30.9 \\
\hline & 60 to 90 & 0.04 & 0.26 & 0.03 & 2.85 & 179.5 \\
\hline & 90 to 200 & 0.04 & 0.26 & 0.03 & 2.85 & 167.4 \\
\hline \multirow{4}{*}{ SS-4 } & 0 to 30 & 0.04 & 0.33 & 0.03 & 1.82 & 81.0 \\
\hline & 30 to 60 & 0.03 & 0.25 & 0.04 & 1.91 & 30.9 \\
\hline & 60 to 90 & 0.04 & 0.26 & 0.03 & 2.85 & 179.5 \\
\hline & 90 to 200 & 0.04 & 0.26 & 0.03 & 2.85 & 167.4 \\
\hline \multirow{4}{*}{ SS-5 } & 0 to 30 & 0.04 & 0.33 & 0.04 & 1.68 & 60.5 \\
\hline & 30 to 60 & 0.04 & 0.25 & 0.03 & 2.37 & 64.3 \\
\hline & 60 to 90 & 0.04 & 0.26 & 0.03 & 2.84 & 179.3 \\
\hline & 90 to 200 & 0.04 & 0.26 & 0.03 & 2.86 & 171.1 \\
\hline \multirow{4}{*}{ SS-6 } & 0 to 30 & 0.04 & 0.33 & 0.04 & 1.68 & 60.5 \\
\hline & 30 to 60 & 0.04 & 0.25 & 0.03 & 2.37 & 64.3 \\
\hline & 60 to 90 & 0.04 & 0.26 & 0.03 & 2.84 & 179.3 \\
\hline & 90 to 200 & 0.04 & 0.26 & 0.03 & 2.86 & 171.1 \\
\hline \multirow{4}{*}{ SS-7 } & 0 to 30 & 0.04 & 0.33 & 0.04 & 1.68 & 60.5 \\
\hline & 30 to 60 & 0.04 & 0.25 & 0.03 & 2.37 & 64.3 \\
\hline & 60 to 90 & 0.04 & 0.26 & 0.03 & 2.84 & 179.3 \\
\hline & 90 to 200 & 0.04 & 0.26 & 0.03 & 2.86 & 171.1 \\
\hline \multirow{4}{*}{ SS-8 } & 0 to 30 & 0.04 & 0.33 & 0.04 & 1.68 & 60.5 \\
\hline & 30 to 60 & 0.04 & 0.25 & 0.03 & 2.37 & 64.3 \\
\hline & 60 to 90 & 0.04 & 0.26 & 0.03 & 2.84 & 179.3 \\
\hline & 90 to 200 & 0.04 & 0.26 & 0.03 & 2.86 & 171.1 \\
\hline
\end{tabular}

Table 3: Root water uptake coefficients (Simunek et al., 2008)

\begin{tabular}{llllll}
\hline Plant & ho $_{\mathbf{0}}(\mathbf{c m})$ & hopt $_{\mathbf{c m}}(\mathrm{cm})$ & $\mathbf{h}_{2 H}(\mathbf{c m})$ & $\mathbf{h}_{2 \mathbf{L}}(\mathbf{c m})$ & $\mathbf{h}_{3}(\mathbf{c m})$ \\
\hline Pasture & -10 & -25 & -200 & -800 & -8000 \\
& & & & & \\
\hline
\end{tabular}

Solute transport parameters: For modeling solute transport process in HYDRUS-1D, nitrate was assumed to not adsorb on the soil particle due to its negative charge. Whereas, 
ammonium adsorbed to the soil particles with an adsorption coefficient $\left(\mathrm{K}_{\mathrm{D}}\right)$ of $3.5 \mathrm{~cm}^{3} \mathrm{~g}^{-1}$ (Hanson et al., 2006). The nitrification rate, $\mu_{\mathrm{w}}\left(\mathrm{day}^{-1}\right)$, also known as first-order decay constant in the nitrification chain reaction was initially chosen as 0.2 day $^{-1}$ (Hanson et al., 2006) but was then calibrated for each layer based on the observed nitrate concentrations in groundwater. The longitudinal dispersivity was considered as one-tenth $(20 \mathrm{~cm})$ of transport length $(200 \mathrm{~cm})$ (Gelhar et al., 1992; Hanson et al., 2006).

\section{Model initial conditions:}

Table 4: Initial N conditions at the study site (modified after Coppi, 2012)

\begin{tabular}{|c|c|c|c|c|c|c|c|c|c|c|}
\hline \multirow[b]{2}{*}{ Plot } & \multirow[b]{2}{*}{$\begin{array}{c}\text { Depth } \\
\text { (cm) }\end{array}$} & \multicolumn{3}{|c|}{$\mathrm{NO}^{-}-\mathrm{N}\left(\mathrm{kg} \mathrm{ha}^{-1}\right)$} & \multicolumn{3}{|c|}{$\mathrm{NH}_{4}{ }^{+}-\mathrm{N}\left(\mathrm{kg} \mathrm{ha}^{-1}\right)$} & \multicolumn{3}{|c|}{ Total N $\left(\mathrm{kg} \mathrm{ha}^{-1}\right)$} \\
\hline & & 2007 & 2008 & 2009 & 2007 & 2008 & 2009 & 2007 & 2008 & 2009 \\
\hline \multirow{4}{*}{ Control grazed } & $0-30$ & 7.46 & 9.10 & 21.80 & 9.31 & 10.73 & 9.09 & 16.77 & 19.83 & 30.89 \\
\hline & $30-60$ & 2.50 & 1.62 & 11.74 & 1.97 & 3.36 & 4.72 & 4.47 & 4.98 & 16.46 \\
\hline & $60-90$ & 0.84 & 0.00 & 6.72 & 1.13 & 1.68 & 2.18 & 1.97 & 1.68 & 8.91 \\
\hline & $90-200$ & 0.88 & 0.00 & 3.50 & 0.81 & 1.41 & 1.94 & 1.69 & 1.41 & 5.44 \\
\hline \multirow{4}{*}{ Full grazed } & $0-30$ & 10.23 & 22.71 & 112.04 & 7.71 & 10.30 & 12.41 & 17.94 & 33.01 & 124.45 \\
\hline & $30-60$ & 2.65 & 1.62 & 19.62 & 2.63 & 4.38 & 6.02 & 5.29 & 6.00 & 25.64 \\
\hline & $60-90$ & 1.81 & 0.00 & 8.69 & 1.09 & 1.52 & 2.53 & 2.90 & 1.52 & 11.22 \\
\hline & $90-200$ & 1.98 & 0.00 & 6.23 & 0.79 & 1.76 & 1.98 & 2.78 & 1.76 & 8.21 \\
\hline \multirow{4}{*}{ Control hayed } & $0-30$ & 4.66 & 5.50 & 43.70 & 8.39 & 9.82 & 15.21 & 13.05 & 15.31 & 58.91 \\
\hline & $30-60$ & 3.25 & 1.46 & 12.99 & 1.37 & 2.52 & 5.96 & 4.62 & 3.98 & 18.95 \\
\hline & $60-90$ & 0.81 & 0.00 & 7.37 & 0.96 & 1.47 & 2.54 & 1.78 & 1.47 & 9.91 \\
\hline & $90-200$ & 0.85 & 0.00 & 1.70 & 0.60 & 1.36 & 2.15 & 1.44 & 1.36 & 3.85 \\
\hline \multirow{4}{*}{ Full hayed } & $0-30$ & 6.51 & 9.07 & 121.14 & 13.28 & 11.82 & 14.69 & 19.79 & 20.89 & 135.82 \\
\hline & $30-60$ & 1.55 & 0.00 & 19.73 & 1.51 & 3.35 & 4.79 & 3.06 & 3.35 & 24.51 \\
\hline & $60-90$ & 0.83 & 0.00 & 6.98 & 0.88 & 1.58 & 1.73 & 1.71 & 1.58 & 8.71 \\
\hline & $90-200$ & 0.93 & 0.00 & 3.60 & 0.73 & 1.61 & 1.63 & 1.66 & 1.61 & 5.23 \\
\hline
\end{tabular}




\section{Chapter 5: Results}

\subsection{Water-flow model calibration}

The observed soil moisture content at $15,45,75$ and $105 \mathrm{~cm}$ depths for SS-1 to SS- 8 was used for calibration. Simulated and calibrated soil moisture content at SS-3 ranged from dry condition at $\sim 0.05 \mathrm{~cm}^{3} / \mathrm{cm}^{3}$ to fully saturated conditions at 0.30 to $0.35 \mathrm{~cm}^{3} / \mathrm{cm}^{3}$ (Figure 12). The simulated soil moisture content at the other SSs are very similar and are given in Appendix-B.

Comparison of VGM parameters estimated by PTF and those by inverse calibration showed small differences in the residual and saturated soil moisture contents $\left(\theta_{\mathrm{r}}\right.$ and $\left.\theta_{\mathrm{s}}\right)$ as well as in $\alpha$ values, whereas $n$ values were changed significantly (both increased and decreased) after calibration. For example, $\theta_{r}, \theta_{s}$ and $\alpha$ values, before and after calibration, did not change significantly for SS-3, whereas $n$ decreased (1.82 to 1.58) for layer 1 and increased (2.85 to 5) for layer 3 (tables 2 and 5).

The difference in observed and simulated soil moisture and soil temperature were analysed by means of RMSE between $0.7 \%$ and $5 \%$, and between 1.26 and 5.36 respectively, NSE between 0.39 and 0.99 , and between 0.55 and 0.97 respectively (table 6). The ME between the observed and simulated moisture content was always below $0.01 \mathrm{~cm}^{3} / \mathrm{cm}^{3}$ which showed no tendency for under-prediction and over-prediction. However, the ME between the observed and simulated soil temperatures was between $-2.96^{\circ} \mathrm{C}$ and $2.14^{\circ} \mathrm{C}$. 


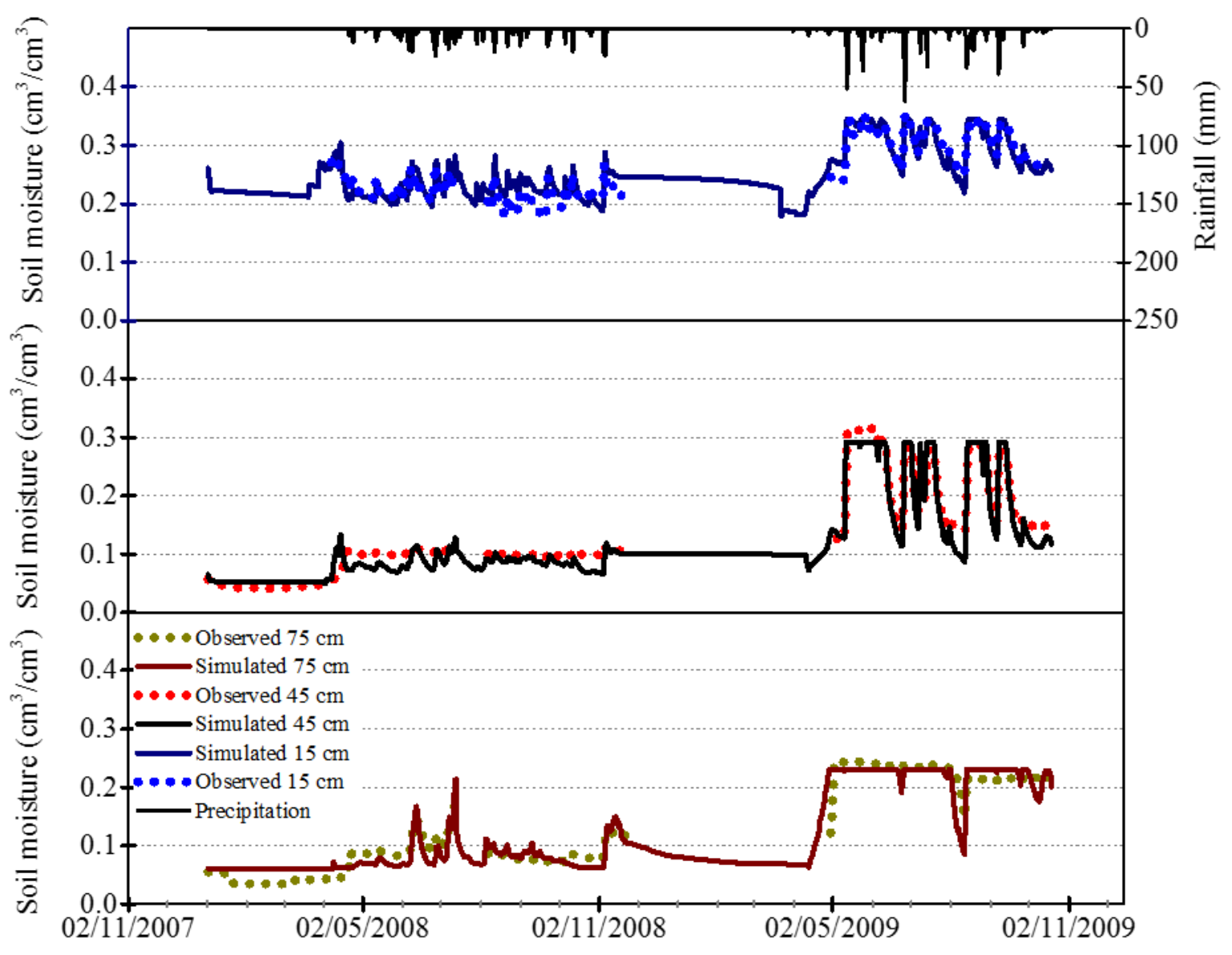

Figure 12: Observed v/s simulated soil moisture contents at depths 15,45 and $75 \mathrm{~cm}$ 
Table 5: VGM parameters after calibration

\begin{tabular}{|c|c|c|c|c|c|c|}
\hline $\begin{array}{c}\begin{array}{c}\text { Soil Sampling } \\
\text { location }\end{array} \\
\end{array}$ & $\begin{array}{c}\text { Depth } \\
{[\mathrm{cm}]}\end{array}$ & $\begin{array}{c}\theta_{\mathbf{r}} \\
{\left[\mathrm{cm}^{3} / \mathrm{cm}^{3}\right]}\end{array}$ & $\begin{array}{c}\theta_{\mathrm{s}} \\
{\left[\mathrm{cm}^{3} / \mathrm{cm}^{3}\right]}\end{array}$ & $\alpha[1 / \mathrm{cm}]$ & $n[-]$ & $\mathrm{K}_{\mathrm{s}}[\mathrm{cm} / \mathrm{d}]$ \\
\hline SS-1 & $\begin{array}{c}0 \text { to } 30 \\
30 \text { to } 60 \\
60 \text { to } 90 \\
90 \text { to } 200\end{array}$ & $\begin{array}{l}0.04 \\
0.02 \\
0.04 \\
0.04\end{array}$ & $\begin{array}{l}0.42 \\
0.26 \\
0.21 \\
0.26\end{array}$ & $\begin{array}{l}0.002 \\
0.02 \\
0.03 \\
0.03\end{array}$ & $\begin{array}{l}1.96 \\
2.80 \\
2.85 \\
2.85\end{array}$ & $\begin{array}{c}158.0 \\
30.0 \\
179.5 \\
200.0\end{array}$ \\
\hline SS-2 & $\begin{array}{c}0 \text { to } 30 \\
30 \text { to } 60 \\
60 \text { to } 90 \\
90 \text { to } 200\end{array}$ & $\begin{array}{l}0.04 \\
0.03 \\
0.04 \\
0.04\end{array}$ & $\begin{array}{l}0.33 \\
0.25 \\
0.25 \\
0.21\end{array}$ & $\begin{array}{l}0.03 \\
0.03 \\
0.03 \\
0.06\end{array}$ & $\begin{array}{l}1.81 \\
3.57 \\
4.55 \\
1.99\end{array}$ & $\begin{array}{c}81.0 \\
30.9 \\
179.5 \\
167.4\end{array}$ \\
\hline SS-3 & $\begin{array}{c}0 \text { to } 30 \\
30 \text { to } 60 \\
60 \text { to } 90 \\
90 \text { to } 200\end{array}$ & $\begin{array}{l}0.09 \\
0.03 \\
0.04 \\
0.04\end{array}$ & $\begin{array}{l}0.34 \\
0.28 \\
0.23 \\
0.26\end{array}$ & $\begin{array}{l}0.03 \\
0.05 \\
0.05 \\
0.03\end{array}$ & $\begin{array}{l}1.58 \\
2.10 \\
5.00 \\
1.50\end{array}$ & $\begin{array}{c}81.0 \\
30.9 \\
179.5 \\
167.4\end{array}$ \\
\hline SS-4 & $\begin{array}{c}0 \text { to } 30 \\
30 \text { to } 60 \\
60 \text { to } 90 \\
90 \text { to } 200\end{array}$ & $\begin{array}{l}0.04 \\
0.03 \\
0.01 \\
0.04\end{array}$ & $\begin{array}{l}0.24 \\
0.23 \\
0.26 \\
0.22\end{array}$ & $\begin{array}{l}0.01 \\
0.03 \\
0.04 \\
0.09\end{array}$ & $\begin{array}{l}2.05 \\
4.69 \\
3.51 \\
2.52\end{array}$ & $\begin{array}{c}81.0 \\
45.0 \\
179.5 \\
167.4\end{array}$ \\
\hline SS-5 & $\begin{array}{c}0 \text { to } 30 \\
30 \text { to } 60 \\
60 \text { to } 90 \\
90 \text { to } 200\end{array}$ & $\begin{array}{l}0.04 \\
0.03 \\
0.04 \\
0.04\end{array}$ & $\begin{array}{l}0.31 \\
0.31 \\
0.28 \\
0.25\end{array}$ & $\begin{array}{l}0.01 \\
0.02 \\
0.03 \\
0.03\end{array}$ & $\begin{array}{l}1.80 \\
2.44 \\
1.47 \\
2.85\end{array}$ & $\begin{array}{c}100.0 \\
30.9 \\
179.5 \\
167.4\end{array}$ \\
\hline SS-6 & $\begin{array}{c}0 \text { to } 30 \\
30 \text { to } 60 \\
60 \text { to } 90 \\
90 \text { to } 200\end{array}$ & $\begin{array}{l}0.02 \\
0.03 \\
0.04 \\
0.04\end{array}$ & $\begin{array}{l}0.42 \\
0.34 \\
0.25 \\
0.25\end{array}$ & $\begin{array}{l}0.01 \\
0.02 \\
0.05 \\
0.03\end{array}$ & $\begin{array}{l}2.70 \\
2.34 \\
3.68 \\
2.85\end{array}$ & $\begin{array}{c}100.0 \\
57.6 \\
185.3 \\
167.4\end{array}$ \\
\hline SS-7 & $\begin{array}{c}0 \text { to } 30 \\
30 \text { to } 60 \\
60 \text { to } 90 \\
90 \text { to } 200\end{array}$ & $\begin{array}{l}0.04 \\
0.03 \\
0.04 \\
0.04\end{array}$ & $\begin{array}{l}0.32 \\
0.29 \\
0.25 \\
0.26\end{array}$ & $\begin{array}{l}0.02 \\
0.02 \\
0.03 \\
0.03\end{array}$ & $\begin{array}{l}1.90 \\
4.50 \\
4.00 \\
2.50\end{array}$ & $\begin{array}{c}81.0 \\
30.9 \\
179.5 \\
167.4\end{array}$ \\
\hline SS-8 & $\begin{array}{c}0 \text { to } 30 \\
30 \text { to } 60 \\
60 \text { to } 90 \\
90 \text { to } 200\end{array}$ & $\begin{array}{l}0.04 \\
0.03 \\
0.04 \\
0.04\end{array}$ & $\begin{array}{l}0.32 \\
0.33 \\
0.25 \\
0.26\end{array}$ & $\begin{array}{l}0.02 \\
0.02 \\
0.03 \\
0.03\end{array}$ & $\begin{array}{l}1.90 \\
2.67 \\
4.00 \\
2.50\end{array}$ & $\begin{array}{c}81.0 \\
30.9 \\
179.5 \\
167.4\end{array}$ \\
\hline
\end{tabular}


Table 6: Model performance

\begin{tabular}{|c|c|c|c|c|c|c|c|}
\hline & \multirow[b]{2}{*}{$\begin{array}{l}\text { Depth } \\
\text { [cm] }\end{array}$} & \multicolumn{3}{|c|}{ Soil Moisture } & \multicolumn{3}{|c|}{ Soil Temperature } \\
\hline & & $\begin{array}{c}\text { RMSE } \\
{\left[\mathrm{cm}^{3} / \mathrm{cm}^{3}\right]}\end{array}$ & $\begin{array}{c}\mathrm{ME} \\
{\left[\mathrm{cm}^{3} / \mathrm{cm}^{3}\right]}\end{array}$ & $\begin{array}{c}\text { NSE } \\
{[-]}\end{array}$ & $\begin{array}{c}\text { RMSE } \\
{\left[{ }^{\circ} \mathrm{C}\right]}\end{array}$ & $\begin{array}{l}\mathrm{ME} \\
{\left[{ }^{\circ} \mathrm{C}\right]}\end{array}$ & $\begin{array}{c}\mathrm{NSE} \\
{[-]}\end{array}$ \\
\hline SS-1 & $\begin{array}{c}15 \\
45 \\
75 \\
105\end{array}$ & $\begin{array}{c}0.042 \\
0.032 \\
0.027 \\
-\end{array}$ & $\begin{array}{c}-0.003 \\
-0.001 \\
-0.005 \\
-\end{array}$ & $\begin{array}{c}0.96 \\
0.84 \\
0.78 \\
-\end{array}$ & $\begin{array}{l}4.80 \\
3.18 \\
2.33 \\
1.87\end{array}$ & $\begin{array}{l}-1.76 \\
-1.15 \\
-0.52 \\
-0.06\end{array}$ & $\begin{array}{l}0.55 \\
0.88 \\
0.92 \\
0.94\end{array}$ \\
\hline SS-2 & $\begin{array}{c}15 \\
45 \\
75 \\
105\end{array}$ & $\begin{array}{c}0.021 \\
0.016 \\
0.038 \\
-\end{array}$ & $\begin{array}{c}0.0007 \\
-0.0015 \\
-0.003 \\
-\end{array}$ & $\begin{array}{c}0.92 \\
0.95 \\
0.81 \\
-\end{array}$ & $\begin{array}{l}5.36 \\
2.77 \\
2.61 \\
1.85\end{array}$ & $\begin{array}{c}-2.96 \\
-1.22 \\
1.38 \\
0.33\end{array}$ & $\begin{array}{l}0.66 \\
0.88 \\
0.83 \\
0.88\end{array}$ \\
\hline SS-3 & $\begin{array}{c}15 \\
45 \\
75 \\
105\end{array}$ & $\begin{array}{l}0.018 \\
0.025 \\
0.029 \\
0.014\end{array}$ & $\begin{array}{c}-0.003 \\
0 \\
0.002 \\
0\end{array}$ & $\begin{array}{l}0.99 \\
0.88 \\
0.83 \\
0.39\end{array}$ & $\begin{array}{l}3.88 \\
2.52 \\
1.72 \\
1.26\end{array}$ & $\begin{array}{l}-2.55 \\
-1.69 \\
-0.87 \\
-0.44\end{array}$ & $\begin{array}{l}0.71 \\
0.93 \\
0.96 \\
0.97\end{array}$ \\
\hline SS-4 & $\begin{array}{c}15 \\
45 \\
75 \\
105\end{array}$ & $\begin{array}{c}0.022 \\
0.024 \\
0.028 \\
-\end{array}$ & $\begin{array}{c}0.001 \\
0 \\
-0.005 \\
-\end{array}$ & $\begin{array}{c}0.79 \\
0.87 \\
0.93 \\
-\end{array}$ & $\begin{array}{l}\text { N/A } \\
\text { N/A } \\
\text { N/A } \\
\text { N/A }\end{array}$ & $\begin{array}{l}\text { N/A } \\
\text { N/A } \\
\text { N/A } \\
\text { N/A }\end{array}$ & $\begin{array}{l}\text { N/A } \\
\text { N/A } \\
\text { N/A } \\
\text { N/A }\end{array}$ \\
\hline SS-5 & $\begin{array}{c}15 \\
45 \\
75 \\
105\end{array}$ & $\begin{array}{l}0.028 \\
0.034 \\
0.031 \\
0.029\end{array}$ & $\begin{array}{c}0 \\
0.001 \\
-0.001 \\
0\end{array}$ & $\begin{array}{l}0.87 \\
0.86 \\
0.40 \\
0.87\end{array}$ & $\begin{array}{l}4.05 \\
2.64 \\
2.61 \\
3.01\end{array}$ & $\begin{array}{c}-0.45 \\
0.50 \\
1.38 \\
2.14\end{array}$ & $\begin{array}{l}0.75 \\
0.86 \\
0.83 \\
0.73\end{array}$ \\
\hline SS-6 & $\begin{array}{c}15 \\
45 \\
75 \\
105\end{array}$ & $\begin{array}{c}0.033 \\
0.029 \\
0.018 \\
-\end{array}$ & $\begin{array}{c}-0.002 \\
-0.007 \\
-0.003 \\
-\end{array}$ & $\begin{array}{c}0.94 \\
0.92 \\
0.96 \\
-\end{array}$ & $\begin{array}{l}2.84 \\
2.17 \\
1.97 \\
2.07\end{array}$ & $\begin{array}{c}-0.17 \\
-0.03 \\
0.45 \\
0.90\end{array}$ & $\begin{array}{l}0.92 \\
0.94 \\
0.94 \\
0.93\end{array}$ \\
\hline SS-7 & $\begin{array}{c}15 \\
45 \\
75 \\
105\end{array}$ & $\begin{array}{l}0.026 \\
0.032 \\
0.033 \\
0.034\end{array}$ & $\begin{array}{c}-0.005 \\
-0.002 \\
0.009 \\
0.008\end{array}$ & $\begin{array}{l}0.89 \\
0.86 \\
0.90 \\
0.81\end{array}$ & $\begin{array}{l}2.72 \\
1.96 \\
1.84 \\
2.04\end{array}$ & $\begin{array}{c}-0.20 \\
0.08 \\
0.57 \\
1.03\end{array}$ & $\begin{array}{l}0.93 \\
0.95 \\
0.95 \\
0.93\end{array}$ \\
\hline SS-8 & $\begin{array}{c}15 \\
45 \\
75 \\
105\end{array}$ & $\begin{array}{l}0.028 \\
0.026 \\
0.050 \\
0.007\end{array}$ & $\begin{array}{c}0.004 \\
0.006 \\
0.024 \\
-0.003\end{array}$ & $\begin{array}{l}0.85 \\
0.89 \\
0.68 \\
0.72\end{array}$ & $\begin{array}{l}\text { N/A } \\
\text { N/A } \\
\text { N/A } \\
\text { N/A }\end{array}$ & $\begin{array}{l}\text { N/A } \\
\text { N/A } \\
\text { N/A } \\
\text { N/A }\end{array}$ & $\begin{array}{l}\text { N/A } \\
\text { N/A } \\
\text { N/A } \\
\text { N/A }\end{array}$ \\
\hline
\end{tabular}

N/A: Observed data were not available. 


\subsection{Recharge}

The recharge estimated at SS-3 using the VGM parameters and after carrying out inverse calibration was simulated to be $150 \mathrm{~mm}$ and $256 \mathrm{~mm}$ for years 2008 and 2009 respectively and the corresponding recharge-precipitation for both the years was calculated as $32.7 \%$ and $49 \%$ respectively. In general, for all SSs (1-8) where recharge was estimated, its value varied between 119 and $186 \mathrm{~mm}$ for 2008 and between 227 and $279 \mathrm{~mm}$ for the year 2009 (table 7).

Table 7: Recharge (mm) and recharge-precipitation ratio (\%) for SS-1 to SS-8 in years 2008 and 2009

\begin{tabular}{|c|c|c|c|c|c|}
\hline & & $\operatorname{Rec}$ & m) & Recharg & tation ratio \\
\hline & Station & 2008 & 2009 & 2008 & 2009 \\
\hline & 1 & 169 & 264 & 36.8 & 50.6 \\
\hline$\approx$ & 2 & 166 & 279 & 36.1 & 53.4 \\
\hline 犊 & 3 & 150 & 256 & 32.7 & 49.0 \\
\hline$\frac{0}{2}$ & 4 & 186 & 256 & 40.5 & 49.0 \\
\hline $\bar{U}$ & 5 & 145 & 227 & 31.6 & 43.5 \\
\hline $\bar{\Xi}$ & 6 & 119 & 238 & 25.9 & 45.6 \\
\hline$E_{4}$ & 7 & 164 & 254 & 35.7 & 48.7 \\
\hline & 8 & 153 & 254 & 33.3 & 48.7 \\
\hline & Min & 119 & 227 & 25.9 & 43.5 \\
\hline & Max & 186 & 279 & 40.5 & 53.4 \\
\hline
\end{tabular}

The recharge-precipitation ratio for all the SSs was simulated between $25.9 \%$ to $40.5 \%$ for the year 2008 and between $43.5 \%$ to $53.4 \%$ for 2009 . Recharge estimated for SS-3, using VGM parameters directly derived from PTF was $165 \mathrm{~mm}(10 \%$ larger than the calibrated value of $150 \mathrm{~mm})$ and $279 \mathrm{~mm}(8.9 \%$ larger than the calibrated value of $256 \mathrm{~mm})$ for years 2008 and 2009 respectively.

Most of the recharge, for SS-3, occurred during the period of snow-melt in April 2008. About $42 \mathrm{~mm}$ of it occurred during this month which was about $28 \%$ of total recharge in 2008 , whereas for the next year, 2009, about $110 \mathrm{~mm}$ of recharge occurred during the month of 
June when due to high precipitation, water table rose close to the surface leading a shorter path for the incoming flux to meet the water table.

\subsection{Sensitivity analysis}

During sensitivity analysis, the VGM parameters $n, \alpha$, and $\mathrm{K}_{\mathrm{s}}$ were evaluated as explained in section 3.4 for the depth $45 \mathrm{~cm}$, within the root zone $(50 \mathrm{~cm}$ depth). The parameter which showed the largest sensitivity to soil moisture content was $n$ (Figure 13). The parameter $\alpha$ showed a lower sensitivity than $n$ and the least sensitive parameter to soil moisture content was determined to be $\mathrm{K}_{\mathrm{s}}$ (Figure 13). For SS-3 (depth: $45 \mathrm{~cm}$ ), changing $n$ from $-20 \%$ to $+20 \%$ impacted the soil moisture content from $-28 \%$ to $+149 \%$ for 2008 and from $-12 \%$ to $+121 \%$ for the year 2009 . However, the change in recharge by changing $n$ from $-20 \%$ to $+20 \%$ was less as compared to the changes in soil moisture content.

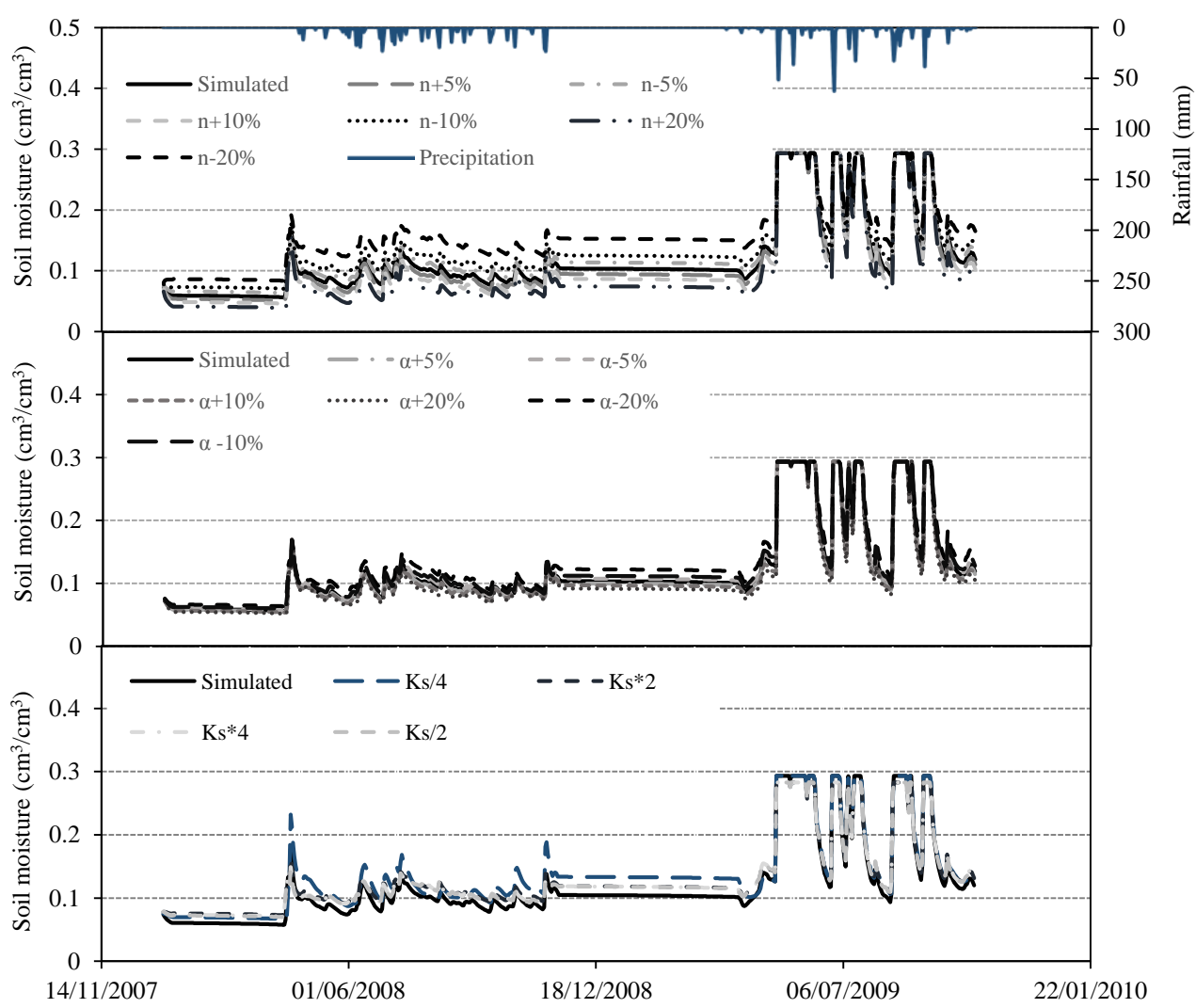

Figure 13: Sensitivity analysis of $\alpha, n$ and $K_{s}$ on soil moisture content at $45 \mathrm{~cm}$ depth 
In 2008 , recharge was reduced by $0.8 \%$ when $n$ was reduced by $20 \%$ whereas it increased by $0.8 \%$ when $n$ was increased by $20 \%$. A similar behaviour of deviation in recharge was achieved for the year 2009. It increased by $4.2 \%$ on increasing $n$ by $20 \%$ whereas it reduced by $6.1 \%$ when $n$ was reduced to $0.8 \times n$ (reduced by $20 \%$ ). Therefore, the results indicated at least one magnitude smaller changes in recharge estimates as compared to soil moisture.

As stated earlier, parameter $\alpha$ showed a less sensitive behaviour on soil moisture as well as on recharge estimates. On increasing $\alpha$ by $20 \%$, the recharge was reduced by $1.2 \%$ in 2008 and increased by $1.7 \%$ in 2009 whereas a reverse behaviour was observed on reducing $\alpha$ by $20 \%$, recharge increased by $1.6 \%$ in 2008 and reduced by $3.6 \%$ in 2009 .

Changing $\mathrm{K}_{\mathrm{s}}$ at a larger scale accounted for greater changes in groundwater recharge. $\mathrm{Ks} * 2$ resulted in $4 \%$ increase in recharge, $\mathrm{Ks} / 2$ lead to $3.6 \%$ decrease, $\mathrm{Ks} * 4$ increased it by $10 \%$ and lastly Ks/4 reduced the groundwater recharged by $9.6 \%$.

\subsection{Water balance}

A water balance for the La Broquerie Pasture and Swine Manure Management Site was evaluated for the years 2008 and 2009 using the calibrated model. The daily simulated soil moisture contents, evapotranspiration and water fluxes at $50 \mathrm{~cm}$ depth were used for the water balance analysis since the depth of $50 \mathrm{~cm}$ represented the end of the root zone. The total precipitation at the study site for years 2008 and 2009 was $488 \mathrm{~mm}$ and $542 \mathrm{~mm}$ respectively (Figure 14) whereas the actual evapotranspiration simulated by HYDRUS-1D was $259.2 \mathrm{~mm}(53.2 \%$ of precipitation) for 2008 and $221.4 \mathrm{~mm}$ for $2009(40.9 \%$ of precipitation).

The water storage changes were determined on a monthly basis for both the years. The summer months were dry for both years which resulted in a deficit in the water balance. The 
surplus water in the soil was observed during the periods of snowmelt in April-May or during the events of heavy rainfall for both the years (table 8).
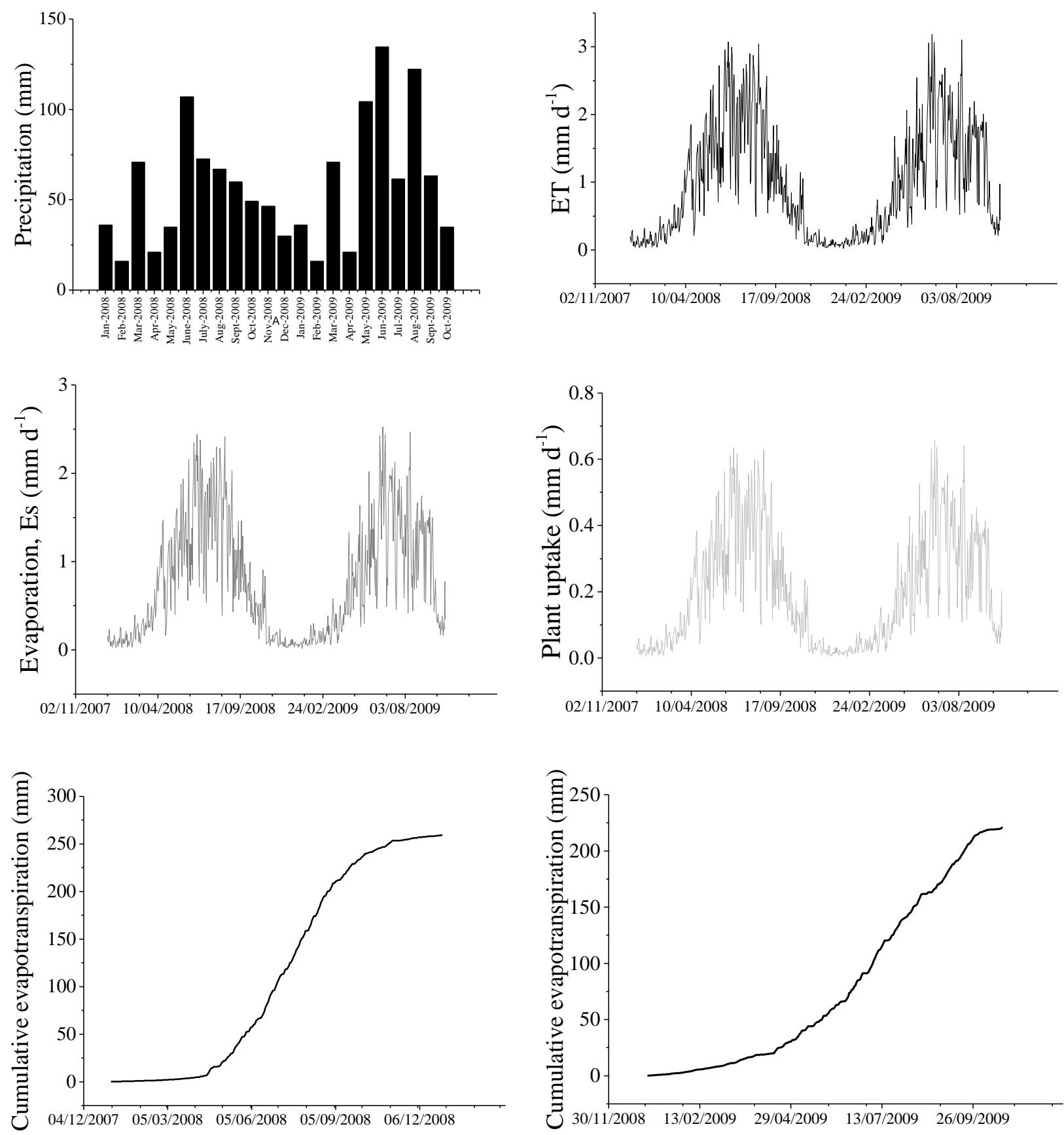

Figure 14: Monthly precipitation, actual evapotranspiration (AET), simulated root water uptake and evaporation 
Table 8: Monthly water balance for 2008 and 2009 (SS-3)

\begin{tabular}{|c|c|c|c|c|c|c|}
\hline $\begin{array}{l}\text { Month- } \\
\text { Year }\end{array}$ & $\begin{array}{l}\text { Infiltration } \\
\quad(\mathbf{m m})\end{array}$ & $\begin{array}{c}\mathbf{E T} \\
(\mathbf{m m})\end{array}$ & $\begin{array}{c}\text { Downward } \\
\text { flux at } 50 \\
\text { cm depth } \\
(\mathrm{mm}) \\
\end{array}$ & $\begin{array}{c}\text { Upward flux } \\
\text { at } 50 \mathrm{~cm} \\
\text { depth }(\mathrm{mm})\end{array}$ & $\begin{array}{c}\text { Recharge } \\
\text { (mm) }\end{array}$ & $\begin{array}{c}\text { Storage } \\
\text { changes }(\mathbf{m m})\end{array}$ \\
\hline Jan-08 & 0.0 & 0.8 & 0.3 & 0.2 & 0.1 & -0.9 \\
\hline Feb-08 & 0.0 & 1.0 & 0.0 & 0.1 & -0.1 & -0.9 \\
\hline Mar-08 & 11.0 & 2.2 & 0.0 & 0.0 & 0 & 8.8 \\
\hline Apr-08 & 120.0 & 12.2 & 62.0 & 0.0 & 42 & 45.9 \\
\hline May-08 & 27.0 & 36.3 & 8.0 & 0.0 & 12 & -17.3 \\
\hline Jun-08 & 63.8 & 43.7 & 11.0 & 0.0 & 15 & 9.1 \\
\hline Jul-08 & 65.0 & 55.2 & 18.0 & 3.0 & 19 & -5.2 \\
\hline Aug-08 & 58.0 & 52.3 & 7.0 & 1.0 & 10 & -0.3 \\
\hline Sep-08 & 42.0 & 29.5 & 12.0 & 0.0 & 12 & 0.5 \\
\hline Oct-08 & 27.0 & 15.3 & 18.2 & 0.0 & 22.2 & -6.5 \\
\hline Nov-08 & 25.0 & 7.7 & 18.0 & 0.0 & 18 & -0.7 \\
\hline Dec-08 & 0.0 & 3.0 & 0.0 & 0.0 & 0 & -2.9 \\
\hline Jan-09 & 0.0 & 2.9 & 0.0 & 0.0 & 0 & -2.8 \\
\hline Feb-09 & 0.0 & 5.4 & 0.0 & 0.0 & 0 & -5.3 \\
\hline Mar-09 & 0.0 & 10.2 & 0.0 & 0.0 & 0 & -10.2 \\
\hline Apr-09 & 9.9 & 13.2 & 0.7 & 10.7 & -10 & 6.7 \\
\hline Мay-09 & 101.0 & 25.8 & 84.5 & 43.0 & 41.5 & 33.7 \\
\hline Jun-09 & 114.0 & 33.8 & 75.0 & 10.4 & 64.6 & 15.5 \\
\hline Jul-09 & 54.0 & 48.5 & 79.0 & 46.0 & 33 & -27.5 \\
\hline Aug-09 & 110.0 & 32.1 & 66.0 & 11.7 & 54.3 & 23.6 \\
\hline Sep-09 & 60.0 & 43.0 & 68.0 & 10.4 & 57.6 & -40.5 \\
\hline Oct-09 & 12.0 & 6.5 & 15.6 & 0.0 & 15.6 & -10.1 \\
\hline \multicolumn{7}{|l|}{ Total } \\
\hline 2008 & 438.8 & 259.2 & 154.5 & 4.5 & 150.0 & 29.6 \\
\hline 2009 & 460.9 & 221.4 & 388.9 & 132.4 & 256.5 & -17.0 \\
\hline
\end{tabular}




\subsection{Solute transport model calibration}

The solute transport parameters related to $\mathrm{N}$ transformations were calibrated based on the observed nitrate concentration in groundwater at all SSs for 2008 and 2009. The calibrated parameters were ammonium adsorption coefficient, $\mathrm{K}_{\mathrm{D}}\left(\mathrm{cm}^{3} \mathrm{~g}^{-1}\right)$ and nitrification rate, $\mu_{\mathrm{w}}$ $\left(\right.$ day $\left.^{-1}\right)$, also known as first-order decay constant in the nitrification chain reaction. The detailed parameters for each layer for all SSs can be seen in table 9. It can be seen in table 9 that $K_{D}$ values obtained after calibration varied between 1.5 and $4.5 \mathrm{~cm}^{3} \mathrm{~g}^{-1}$ whereas $\mu_{\mathrm{w}}$ varied between 0.1 and 0.7 day $^{-1}$ for different SSs.

Table 9: Solute transport ( $\mathrm{N}$ transformations) parameters obtained after model calibration

\begin{tabular}{|c|c|c|c|}
\hline Soil Sampling location & $\begin{array}{l}\text { Depth } \\
{[\mathrm{cm}]}\end{array}$ & $\begin{array}{l}\text { Ammonium adsorption } \\
\text { coefficient, } K_{D}\left(\mathrm{~cm}^{3} \mathrm{~g}^{-1}\right)\end{array}$ & $\begin{array}{l}\text { First-order decay } \\
\text { constant, } \mu_{\mathrm{w}}\left(\text { day }^{-1}\right)\end{array}$ \\
\hline \multirow{4}{*}{ SSs-1, 2, $3 \& 4$} & 0 to 30 & 2.3 & 0.2 \\
\hline & 30 to 60 & 3.5 & 0.2 \\
\hline & 60 to 90 & 3.5 & 0.2 \\
\hline & 90 to 200 & 3.5 & 0.1 \\
\hline \multirow{4}{*}{ SSs-5, 6, $7 \& 8$} & 0 to 30 & 1.5 & 0.1 \\
\hline & 30 to 60 & 3.5 & 0.2 \\
\hline & 60 to 90 & 2.5 & 0.4 \\
\hline & 90 to 200 & 3.5 & 0.2 \\
\hline \multirow{4}{*}{ SS-9 } & 0 to 30 & 3.5 & 0.4 \\
\hline & 30 to 60 & 4.5 & 0.4 \\
\hline & 60 to 90 & 3.5 & 0.7 \\
\hline & 90 to 200 & 3.5 & 0.2 \\
\hline \multirow{4}{*}{ SS-10 } & 0 to 30 & 3.5 & 0.2 \\
\hline & 30 to 60 & 3.5 & 0.1 \\
\hline & 60 to 90 & 3.5 & 0.2 \\
\hline & 90 to 200 & 3.5 & 0.4 \\
\hline \multirow{4}{*}{ SS-11 } & 0 to 30 & 3.5 & 0.4 \\
\hline & 30 to 60 & 4.5 & 0.4 \\
\hline & 60 to 90 & 4.5 & 0.4 \\
\hline & 90 to 200 & 3.5 & 0.1 \\
\hline \multirow{4}{*}{ SS-13 } & 0 to 30 & 4.5 & 0.2 \\
\hline & 30 to 60 & 4.5 & 0.3 \\
\hline & 60 to 90 & 3.5 & 0.2 \\
\hline & 90 to 200 & 4.5 & 0.3 \\
\hline
\end{tabular}




\begin{tabular}{cccc} 
& 0 to 30 & 3.5 & 0.2 \\
SS-14 & 30 to 60 & 3.5 & 0.2 \\
& 60 to 90 & 3.5 & 0.1 \\
& 90 to 200 & 3.5 & 0.1 \\
SS-15 & 0 to 30 & 3.5 & 0.2 \\
& 30 to 60 & 3.5 & 0.2 \\
& 60 to 90 & 3.5 & 0.2 \\
& 90 to 200 & 3.5 & 0.2 \\
SS-16 & 0 to 30 & 3.5 & 0.2 \\
& 30 to 60 & 3.5 & 0.2 \\
& 60 to 90 & 3.5 & 0.5 \\
& 90 to 200 & 3.5 & 0.2 \\
\hline
\end{tabular}

The differences in observed and simulated nitrate concentration in groundwater were analysed by means of RMSE between 0.023 and $5.12 \mathrm{mg} \mathrm{NO}-\mathrm{N} \mathrm{L}^{-1}$, NSE between 0.66 and 0.96 and the ME between -1.03 $\mathrm{mg} \mathrm{NO}_{3}-\mathrm{N} \mathrm{L}^{-1}$ and $1.05 \mathrm{mg} \mathrm{NO}_{3}-\mathrm{N} \mathrm{L}^{-1}$ (table 10). Figures 1520 show the observed versus simulated nitrate concentration in groundwater for all SSs.

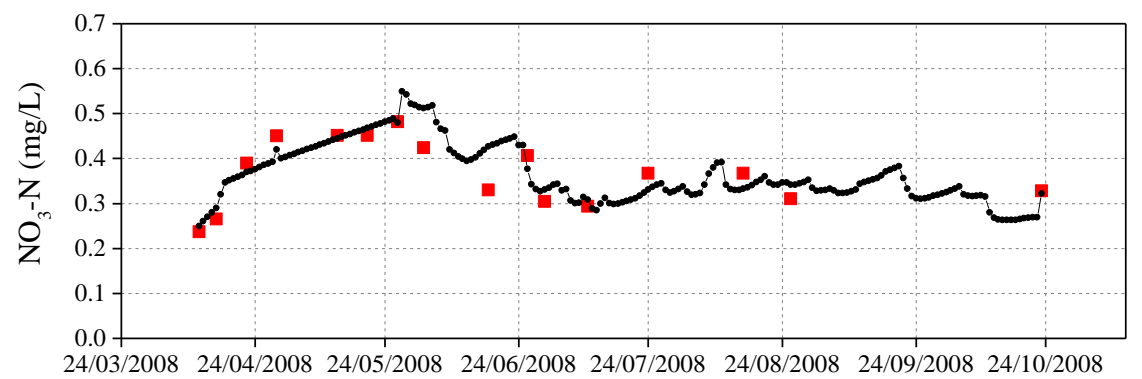

(a)

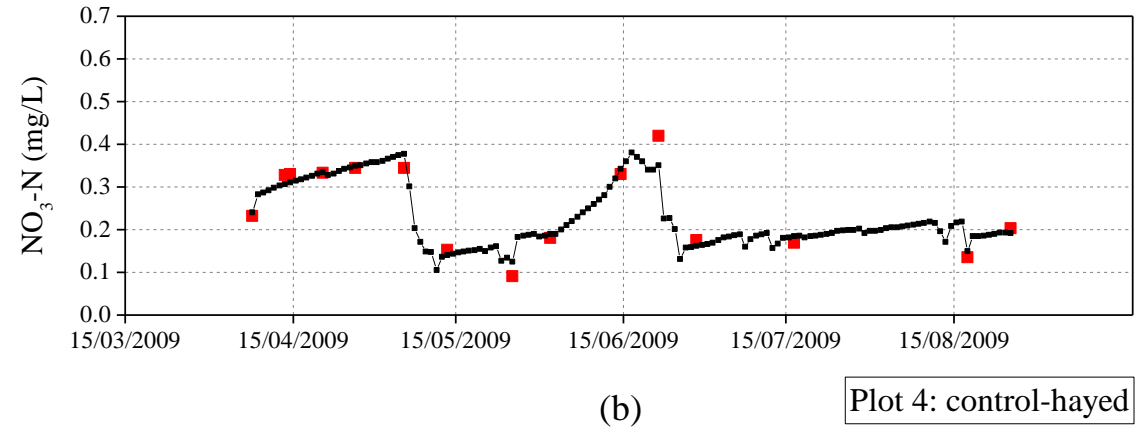

- Observed (average) nitrate concentration at SS-1, SS-2, SS-3 \& SS-4 - - Simulated nitrate concentration

Figure 15: Simulated v/s observed nitrate concentration in groundwater for (a) 2008 and (b) 2009 for SSs 1, 2, 3 \& 4 


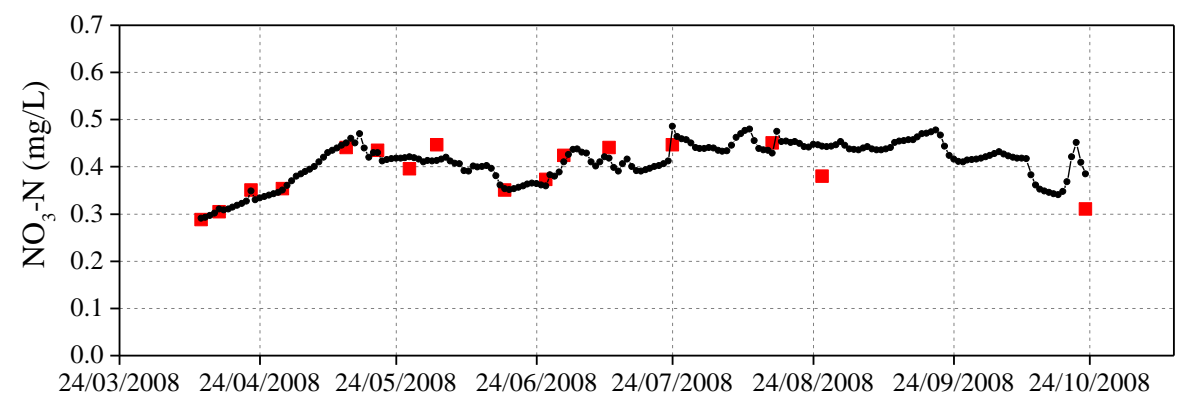

(a)

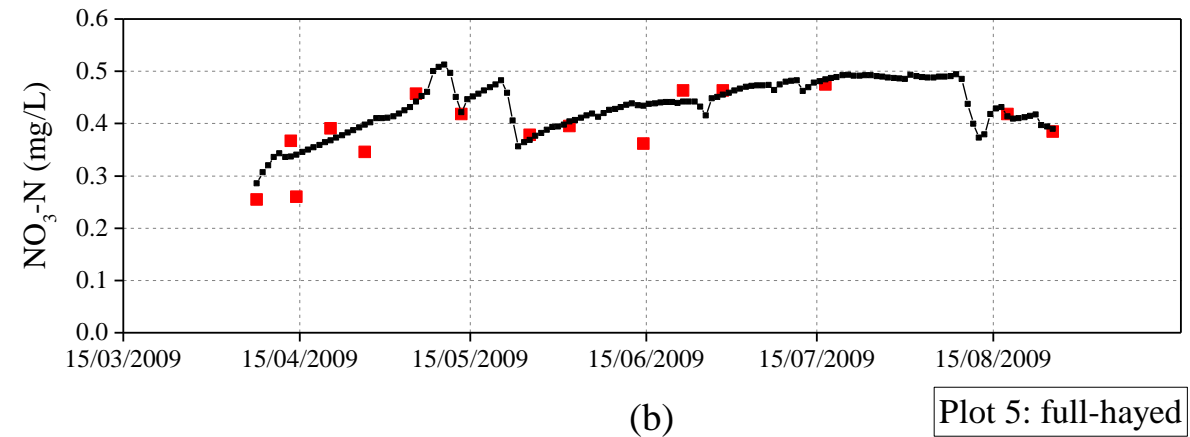

- Observed (average) nitrate concentration at SS-5, SS-6, SS-7 \& SS-8

$\longrightarrow$ - Simulated nitrate concentration

Figure 16: Simulated v/s observed nitrate concentration in groundwater over the years (a) 2008 and (b) 2009 for SS-5, SS-6, SS-7 \& SS-8

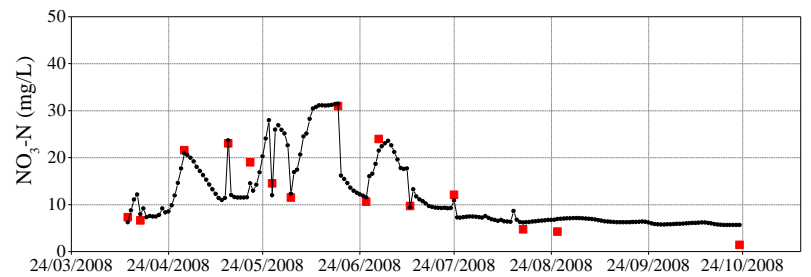

(a)

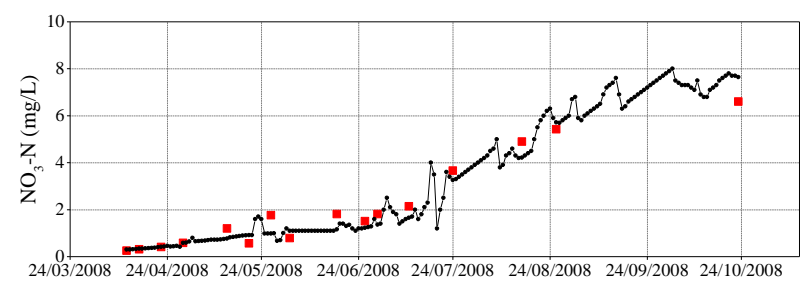

(c)

- Observed —- Simulated

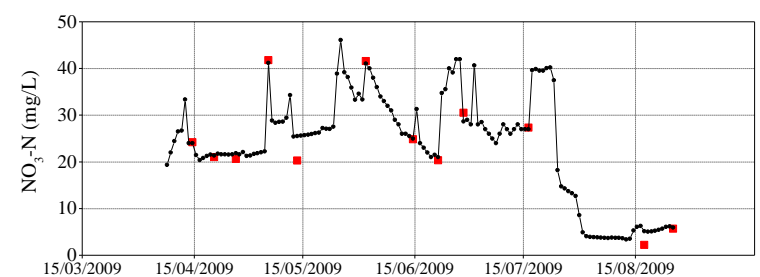

(b)

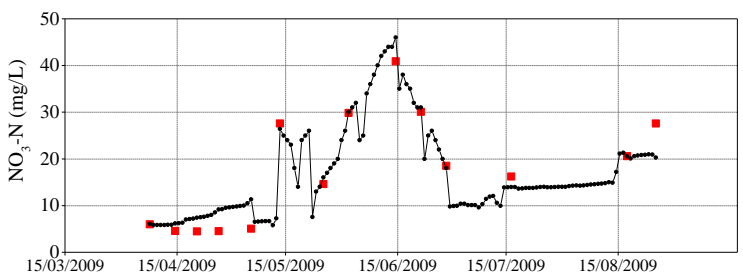

(d)

SS-13, bare earth area, Plot 7: control-grazed

Figure 17: Simulated v/s observed nitrate concentration in groundwater during the years for the BEAs (SS-9 and SS-13 in plots 4 and 7 respectively) over the years (a), (c) 2008 and (b), (d) 2009 


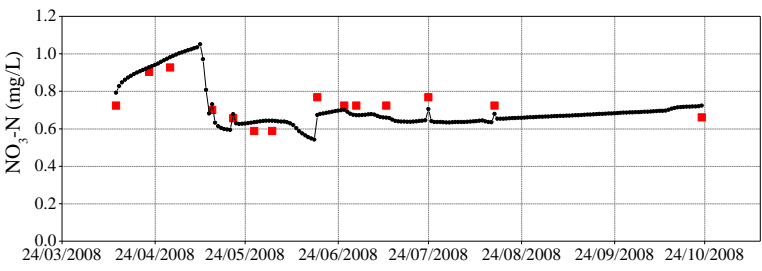

(a)

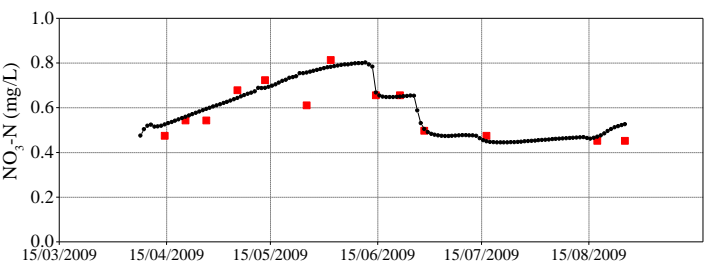

(b)

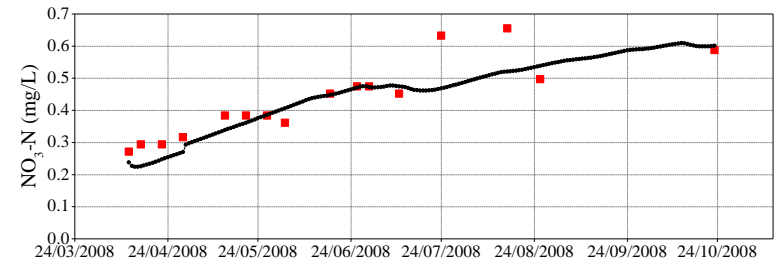

(c)

- Observed —- Simulated

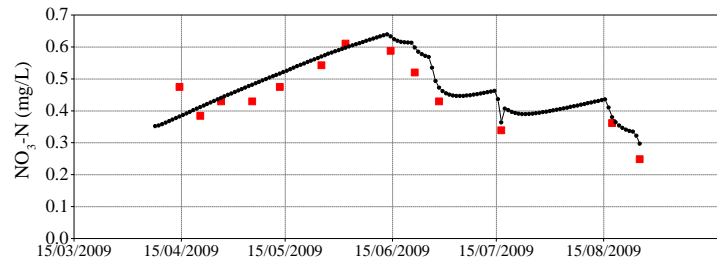

(d)

SS-14, Plot 7: control-grazed

Figure 18: Simulated v/s observed nitrate concentration in groundwater for SSs 10 \& 14 in plots 1 and 7 respectively over the years (a), (c) 2008 and (b), (d) 2009

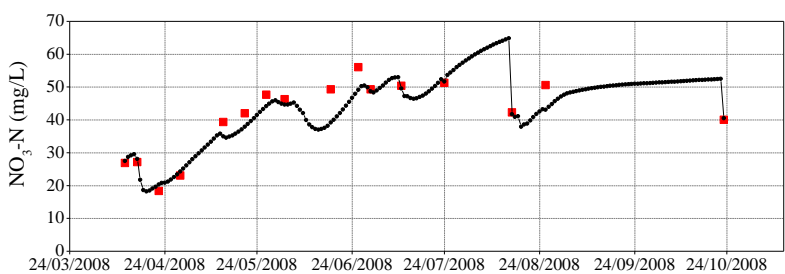

(a)

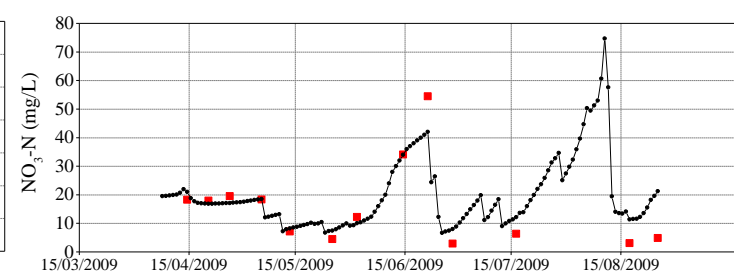

(b)

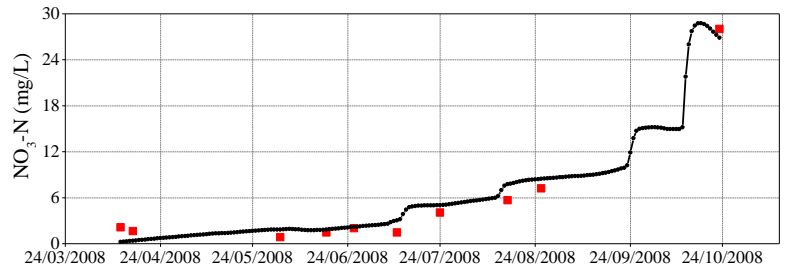

- Observed —- - Simulated

(c)

SS-15, bare earth area, Plot 11: full-grazed

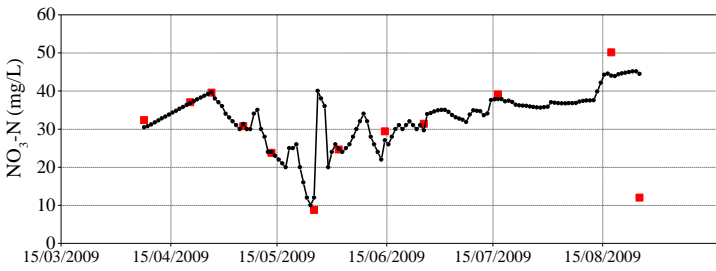

(d)

Figure 19: Simulated v/s observed nitrate concentration in groundwater during the years for the BEAs (SSs 11 and 15 in plots 3 and 11 respectively) over the years (a), (c) 2008 and (b), (d) 2009

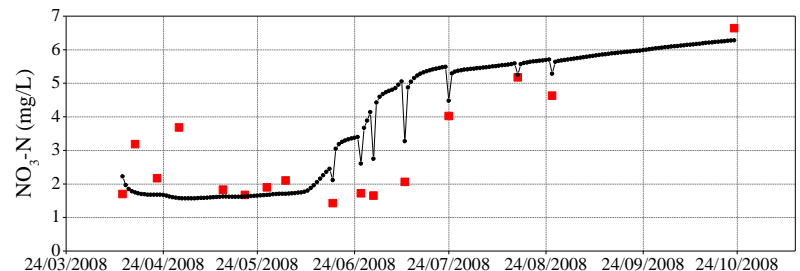

(c)

- Observed - - - Simulated

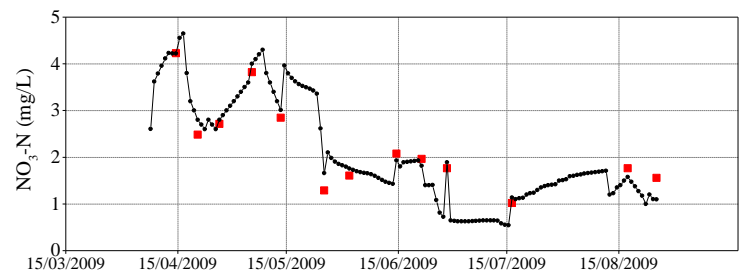

(d)

SS-16, Plot 11: full-grazed

Figure 20: Simulated v/s observed nitrate concentration in groundwater for SS-16 in plot 11 over the years 2008 and 2009 
Table 10: Performance of the solute transport model

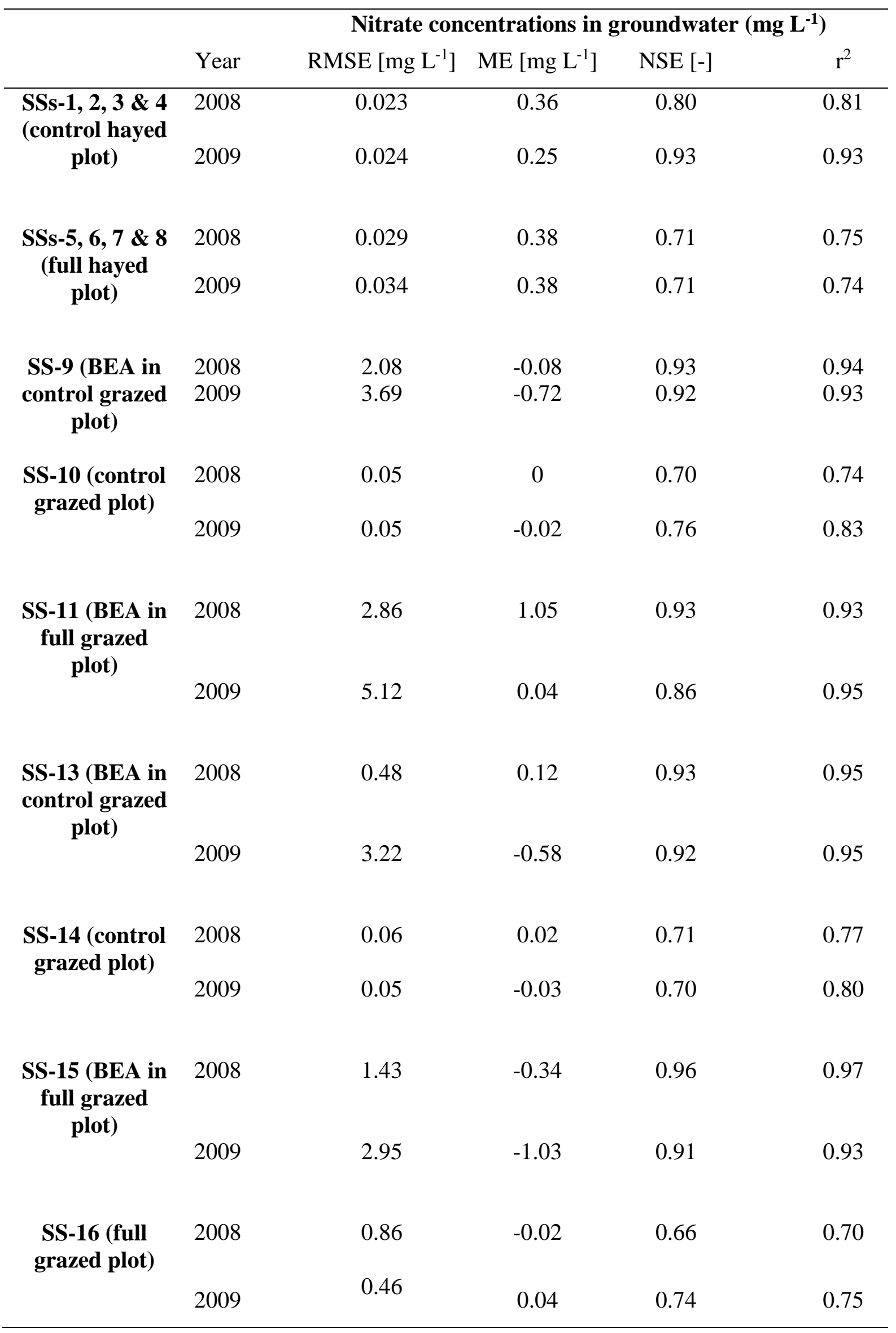




\subsection{Crop nitrogen uptake}

The root $\mathrm{NH}_{4}{ }^{+}$and $\mathrm{NO}_{3}{ }^{-}$uptake were simulated in HYDRUS-1D as 'passive root uptake' since the concentrations of both $\mathrm{NH}_{4}{ }^{+}$and $\mathrm{NO}_{3}{ }^{-}$in soil were always above the pasture $\mathrm{N}$ requirement. The root $\mathrm{N}$ uptake in hayed plots was significantly greater than the grazed plots (Figure 21). The uptake process became faster after the application of manure in full-hayed (fig 20 (c), (d)) and full-grazed treatment plots (fig 20 (g), (h)) as pasture started to grow quickly and utilize the crop-available $\mathrm{N}$ after the application of manure during both years. The simulated cumulative total $\mathrm{N}$ uptake by grass pasture for control-hayed, full-hayed, control-grazed and full-grazed treatment plots were 9, 72.4, 2.6 and $11.4 \mathrm{~kg} / \mathrm{ha} / \mathrm{year}$ respectively whereas the observed cumulative total $\mathrm{N}$ uptake for the same plots were $10 \pm 1$, $67 \pm 7,3 \pm 0.1$ and $11 \pm 0.5 \mathrm{~kg} / \mathrm{ha} /$ year respectively (Coppi, 2012).

For both years, $\mathrm{N}$ was mostly utilized by roots in $\mathrm{NO}_{3}{ }^{-}$form which accounted for about $76.2 \%$ of the total $\mathrm{N}$ uptake on an average. Since there were no observed root $\mathrm{N}$ uptake data available at monthly or weekly intervals, only the yearly observed cumulative $\mathrm{N}$ uptake was compared with the simulated values as mentioned in the previous paragraph. 

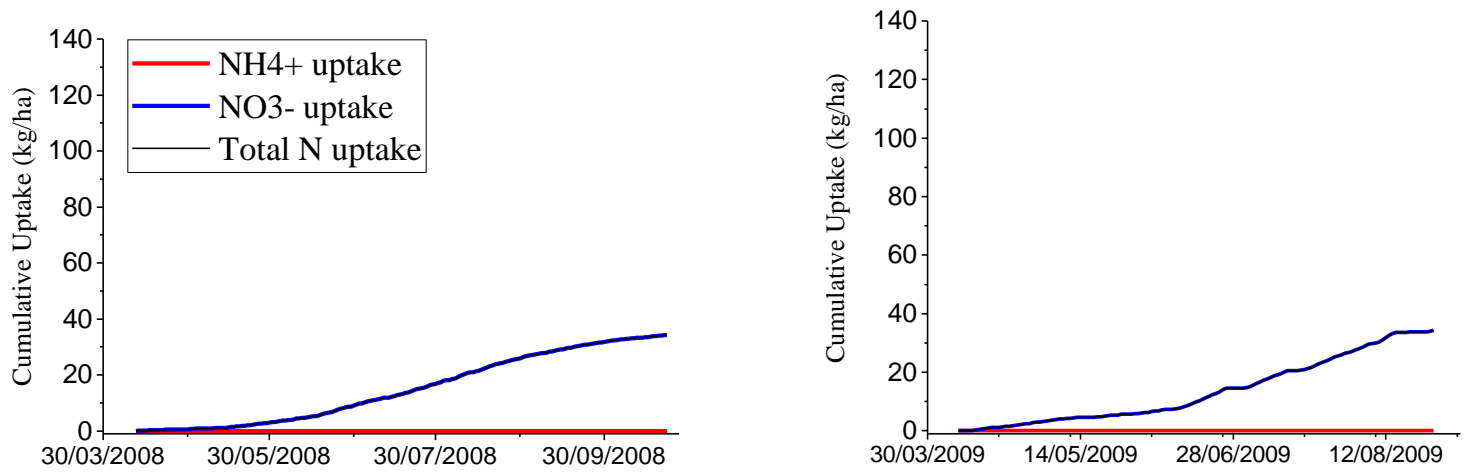

(a)

Plot: control-hayed

(b)
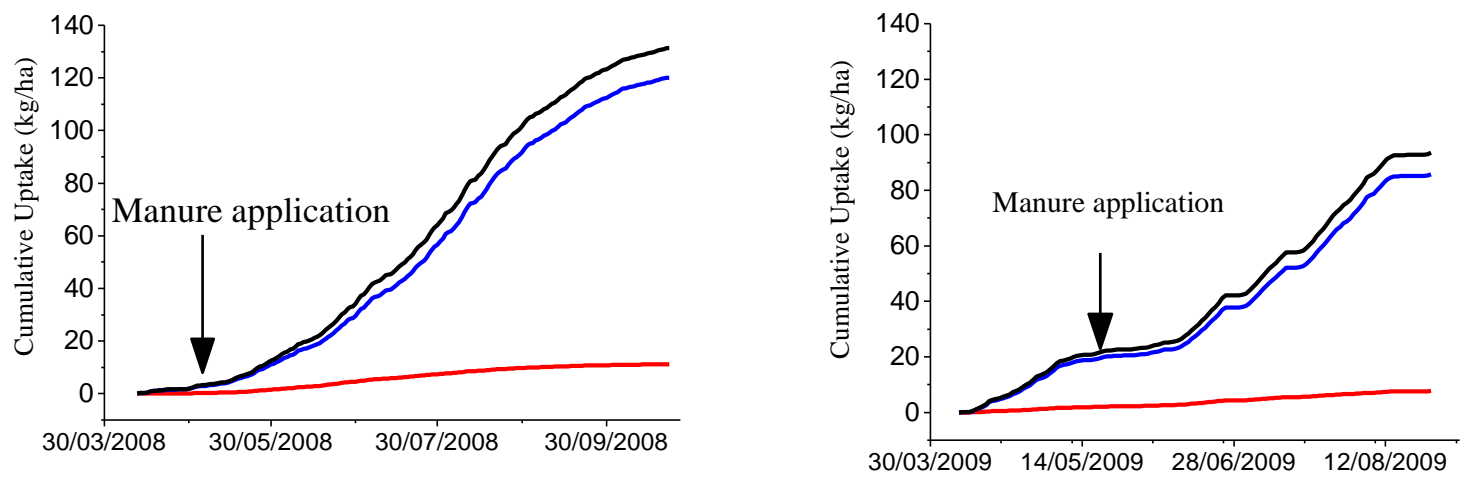

(c)

Plot: full-hayed
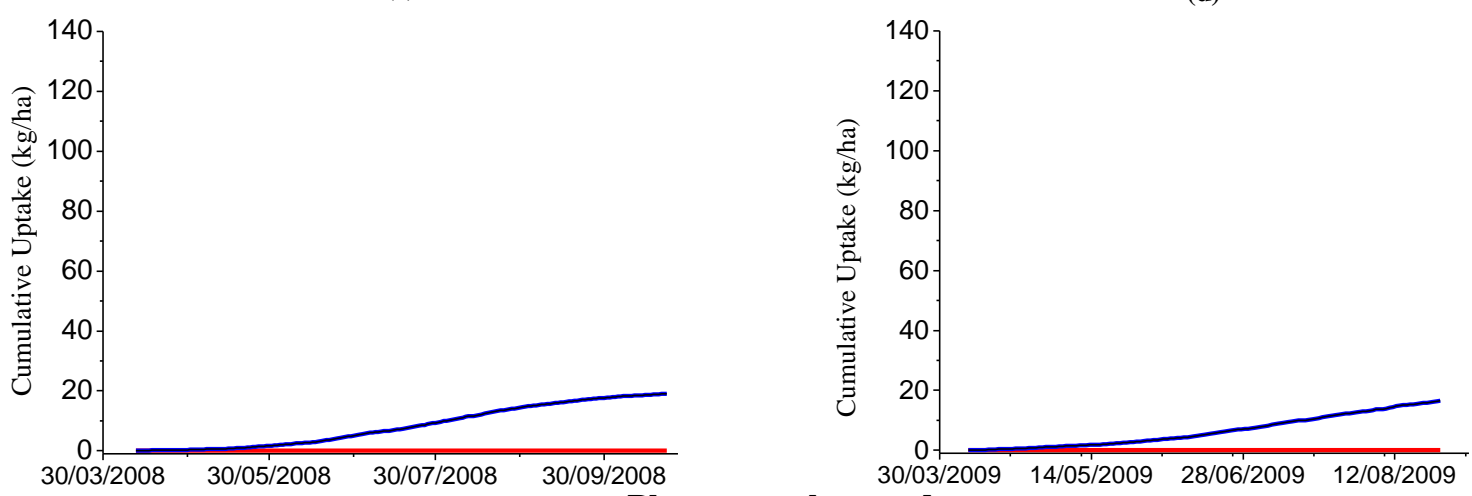

(e)

Plot: control-grazed

(f)

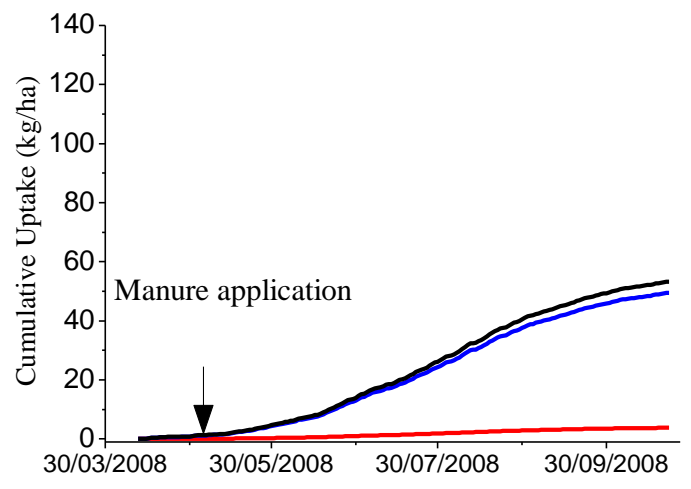

(g)

Plot: full-grazed

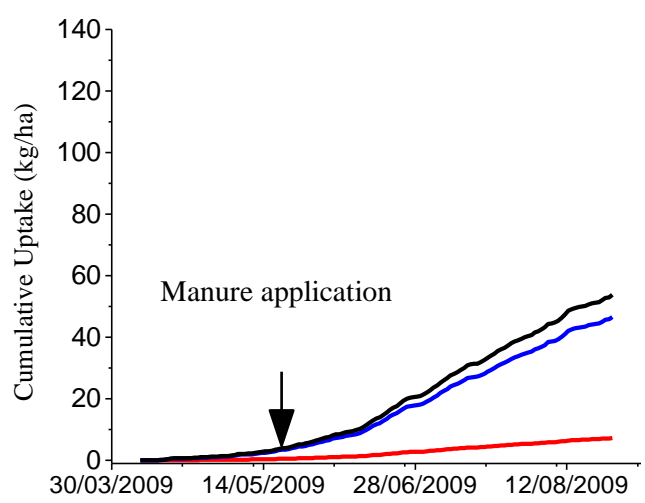

(h)

Figure 21: Simulated cumulative $\mathrm{N}\left(\mathrm{NH}_{4}{ }^{+}, \mathrm{NO}_{3}{ }^{-}\right.$and total) uptake $(\mathrm{kg} / \mathrm{ha})$ for different plots during 2008 (a), (c), (d), (g) and 2009 (b), (d), (f), (h) 
5.7 Nitrate and ammonium leaching
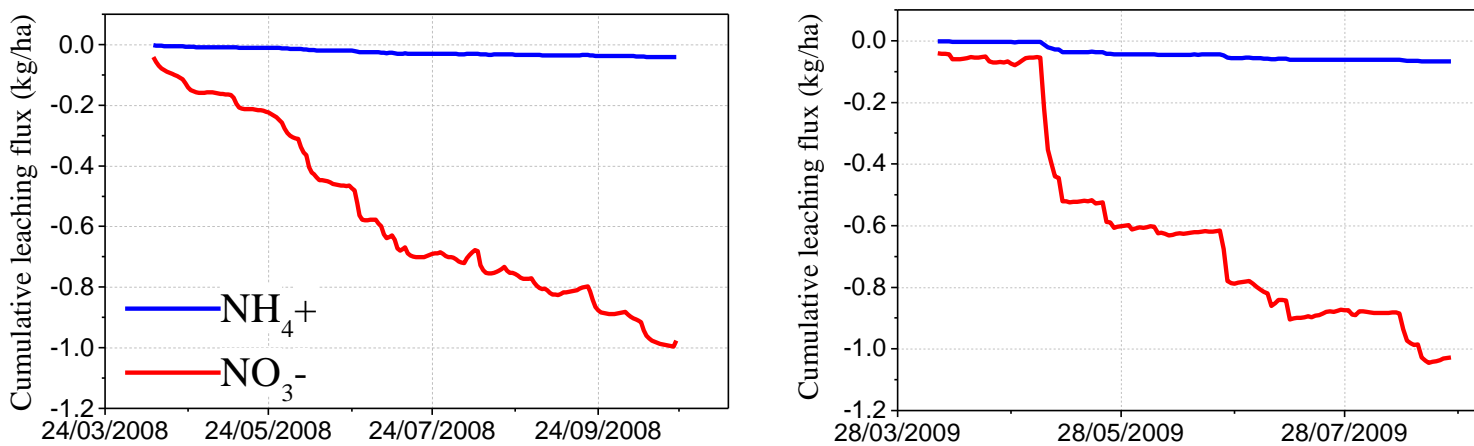

(a)

Plot: control-hayed

(b)
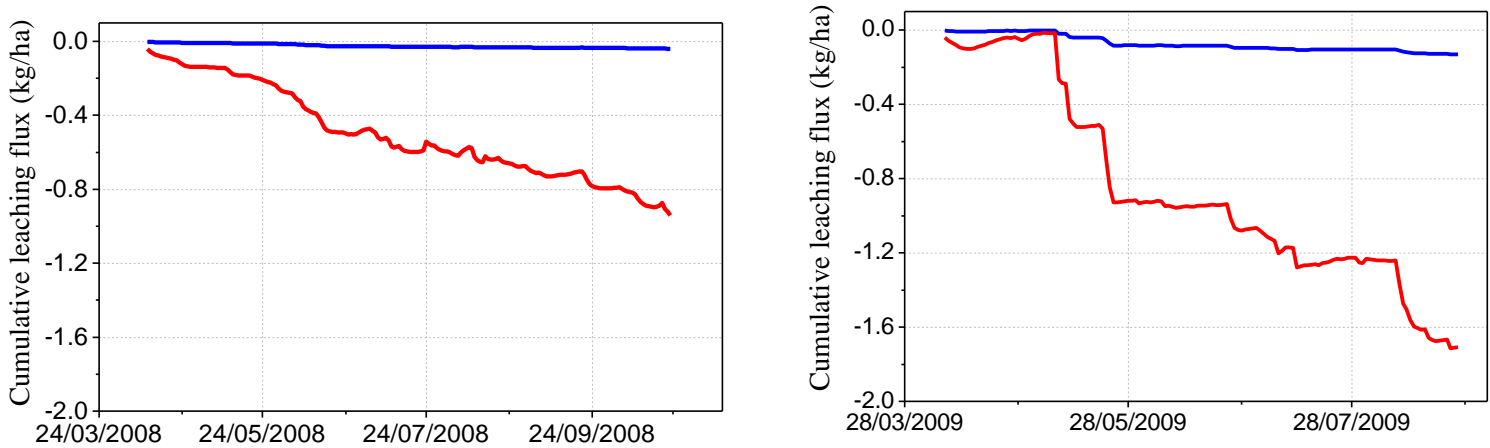

(c)

Plot: full-hayed

(d)
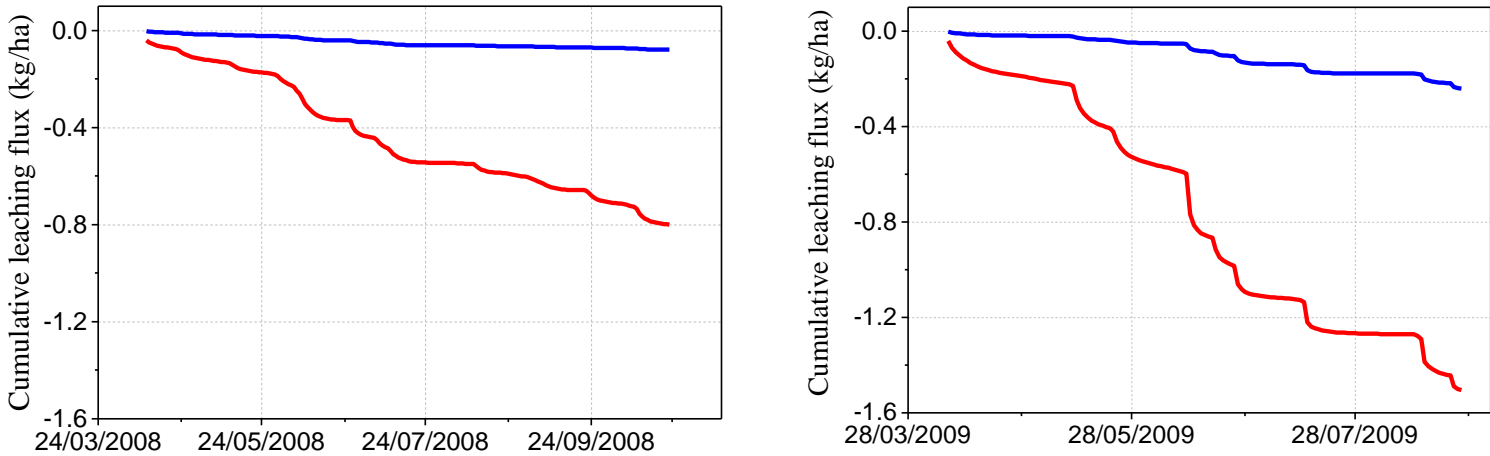

(e)

Plot: control-grazed

(f)
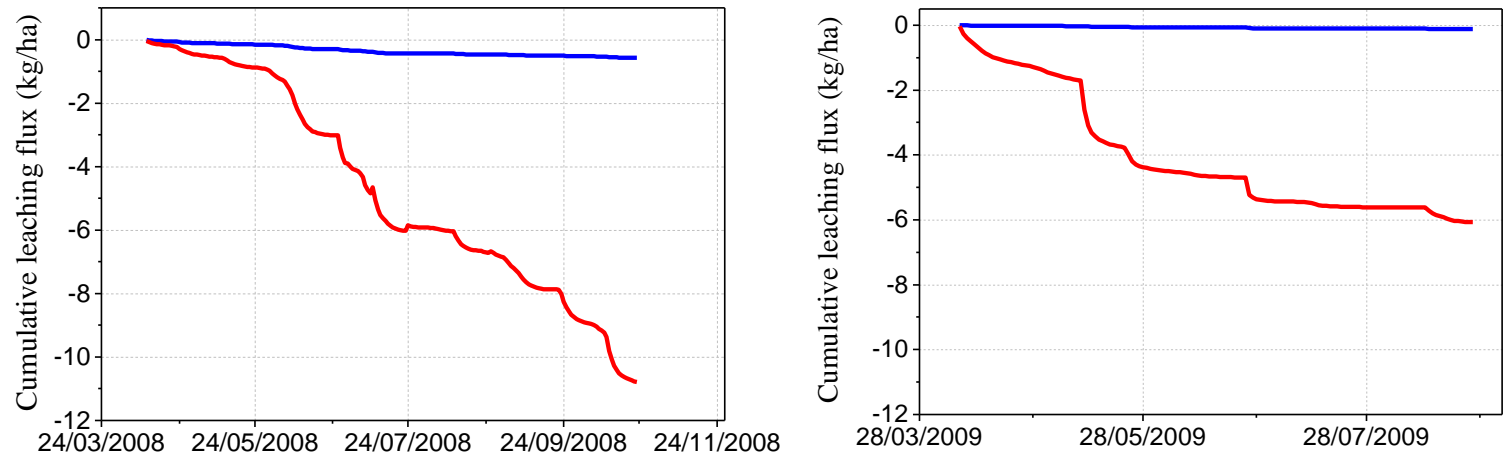

(g)

Plot: full-grazed

(h)

Figure 22: Cumulative $\mathrm{NH}_{4}{ }^{+}$and $\mathrm{NO}_{3}{ }^{-}$leaching (kg/ha) for different plots during 2008 (a), (c), (d), (g) and 2009 (b), (d), (f), (h) 
Figure 22 shows the cumulative $\mathrm{N}$ leaching fluxes at $50 \mathrm{~cm}$ depth (root zone depth) during 2008 and 2009. The cumulative vertical leaching flux of $\mathrm{NH}_{4}{ }^{+}$for all types of treatment plots was always less than $0.3 \mathrm{~kg} / \mathrm{ha} /$ year since the concentration of $\mathrm{NH}_{4}{ }^{+}$in soil was always below $0.02 \mathrm{mg} \mathrm{L}^{-1}$ as mentioned by Coppi (2012). In plots where manure was applied once (full treatment) or twice a year (split treatment), $\mathrm{NH}_{4}{ }^{+}$leaching fluxes were less than $1 \mathrm{~kg} / \mathrm{ha} / \mathrm{year}$ (Figure 22) even though manure contained $\mathrm{N}$ mostly in the ammonium form.

$\mathrm{NO}_{3}{ }^{-}$was observed to be transported downward quickly into the soil along with the leaching water. The cumulative $\mathrm{NO}_{3}{ }^{-}$leaching flux varied differently according to the plot type. For example, the cumulative $\mathrm{NO}_{3}{ }^{-}$leaching fluxes for control-grazed and control-hayed treatment plots were $0.97 \mathrm{~kg} / \mathrm{ha}$ and $0.80 \mathrm{~kg} / \mathrm{ha}$ respectively for 2008 and $1.50 \mathrm{~kg} / \mathrm{ha}$ and $1.02 \mathrm{~kg} / \mathrm{ha}$ respectively for 2009. Since manure was applied in full-hayed and full-grazed treatment plots, the $\mathrm{NO}_{3}^{-}$leaching fluxes for these plots were larger than those observed in control treatment plots.

Results indicated that even after the application of manure in full-hayed plot, the leaching fluxes $(0.94 \mathrm{~kg} / \mathrm{ha}$ in 2008 and $1.7 \mathrm{~kg} / \mathrm{ha}$ in 2009) were somehow comparable to that in control-treatment plots whereas the fluxes increased to $10.8 \mathrm{~kg} / \mathrm{ha}$ in 2008 and $6.0 \mathrm{~kg} / \mathrm{ha}$ in 2008 for the full-grazed type plot.

There were significant $\mathrm{NO}_{3}^{-}$leaching fluxes simulated in the BEAs (Figure 23). As mentioned before, the BEAs in both full-grazed and control-grazed plots were generated due to the animal congregation. The $\mathrm{NO}_{3}{ }^{-}$leaching fluxes for BEAs in control grazed plots were $262 \mathrm{~kg} / \mathrm{ha}$ in 2008 and $429 \mathrm{~kg} / \mathrm{ha}$ in 2009 whereas, for BEAs in full-grazed plots, the leaching fluxes were $1080 \mathrm{~kg} / \mathrm{ha}$ in 2008 and $714 \mathrm{~kg} / \mathrm{ha}$ in 2009. 


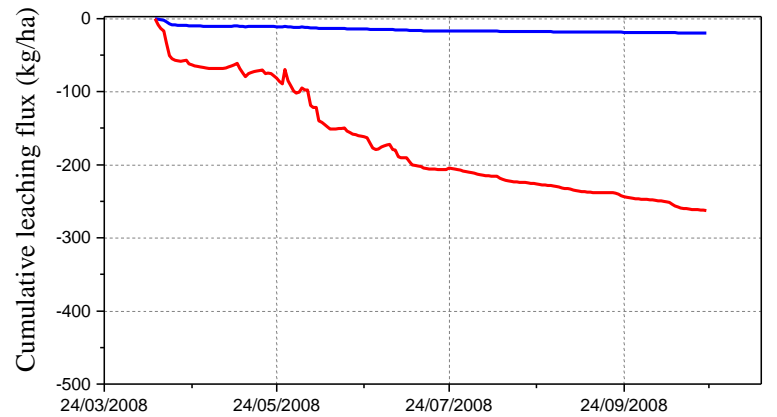

(a)

Bare earth area in plot: control-grazed
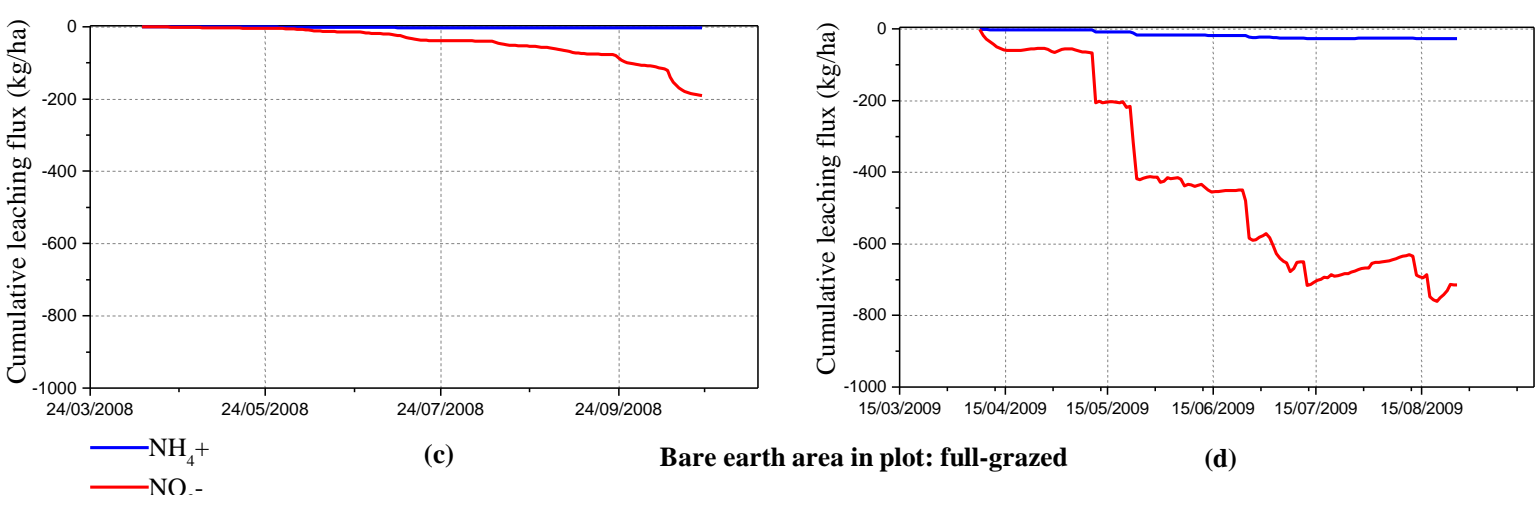

Figure 23: Simulated cumulative $\mathrm{N}\left(\mathrm{NH}_{4}{ }^{+}\right.$and $\left.\mathrm{NO}_{3}{ }^{-}\right)$leaching fluxes $(\mathrm{kg} / \mathrm{ha})$ for BEAs in different plots during 2008 (a), (c) and 2009 (b), (d)

\subsection{Sensitivity analysis (nitrate leaching)}

The sensitivity of VGM parameters $n, \alpha$, and $\mathrm{K}_{\mathrm{s}}$ on nitrate leaching was evaluated as explained in section 3.7. The parameter which showed the largest sensitivity to nitrate leaching was $\alpha$ (Figure 24). The parameter $\mathrm{K}_{\mathrm{s}}$ showed a lower sensitivity than $\alpha$ and the least sensitive parameter to nitrate leaching was determined to be $n$ (Figure 24). Nitrate leaching was reduced by $4.79 \%$ when $n$ was reduced by $20 \%$ whereas it increased by $4.45 \%$ when $n$ was increased by $20 \%$. On increasing $\mathrm{K}_{\mathrm{s}}$ to $\mathrm{K}_{\mathrm{s}} * 5$, the nitrate leaching was increased by $6.4 \%$. However, it reduced by $2.42 \%$ when $\mathrm{K}_{\mathrm{s}}$ was decreased to $\mathrm{K}_{\mathrm{s}} / 25$.

Parameter $\alpha$ showed the highest sensitivity on nitrate leaching. Leaching increased by $12.5 \%$ on decreasing $\alpha$ by $20 \%$ whereas it decreased by $6.95 \%$ when $\alpha$ was increased by $20 \%$ (Figure 24). 


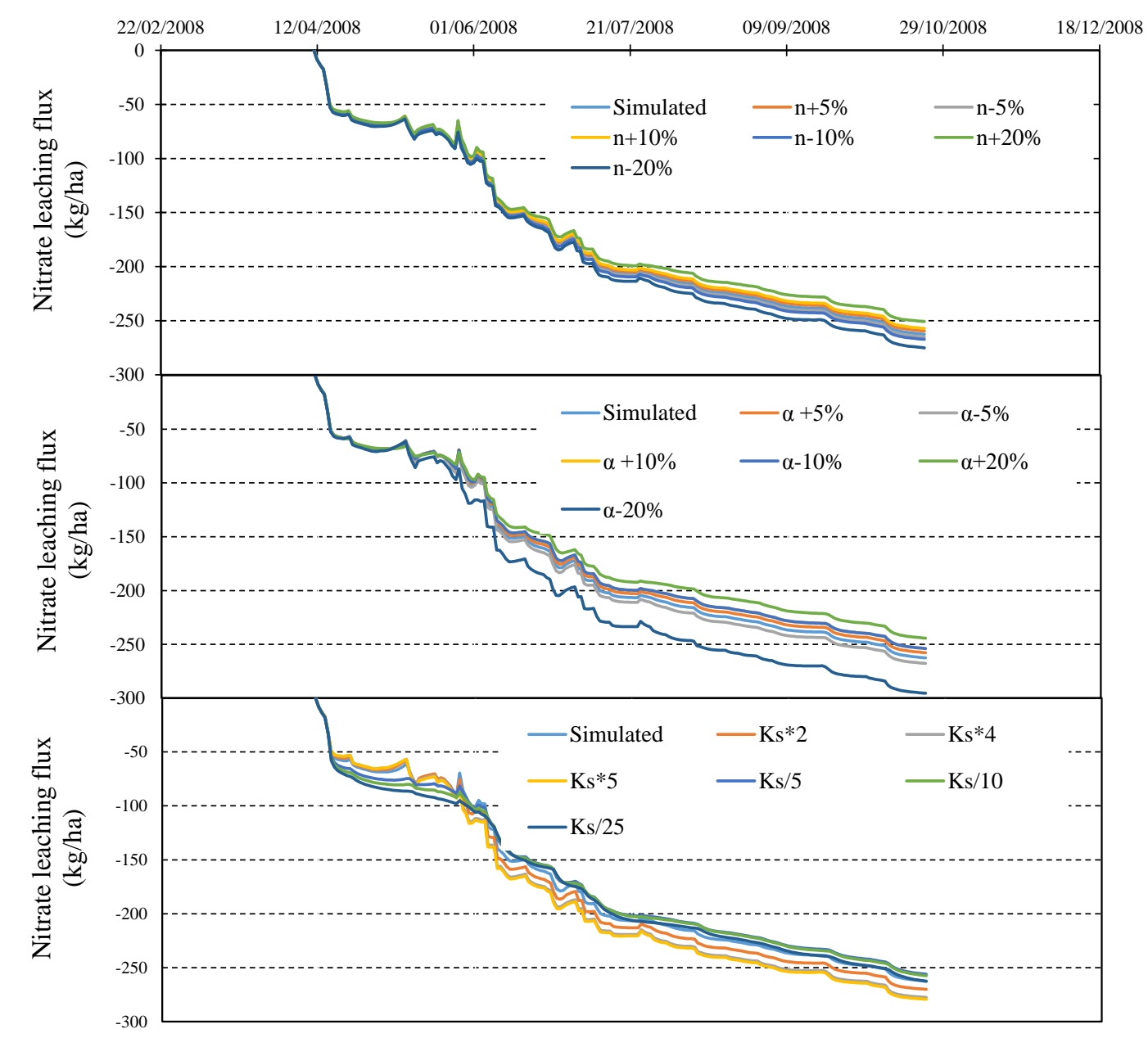

Figure 24: Sensitivity analysis of $\alpha, n$, and $K_{\mathrm{s}}$ on nitrate leaching $(\mathrm{kg} / \mathrm{ha})$ at SS-9

\subsection{Nitrogen balance}

It is critical to analyze the $\mathrm{N}$ balance for understanding how efficiently the grown pasture utilized the $\mathrm{N}$ added to soil via liquid hog manure and how much $\mathrm{N}$ was lost due to various processes. The dominant inputs of $\mathrm{N}$ to the soil were through the application of liquid hog manure in single-treatment plots and through animal excretion in the BEAs. Control treatment plots did not receive any slurry throughout the period of study, so the pasture grown in these plots utilized $\mathrm{N}$ available in the soil from previous years. $\mathrm{N}$ uptake by the roots of grown pasture and leaching were regarded as output $\mathrm{N}$ components which prevented the nitrate leaching. The leaching losses were greater in the BEAs as compared to the other parts of the field due to no vegetation and thus no root $\mathrm{N}$ uptake (table 11). The $\mathrm{N}$ uptake 
efficiency for the full-grazed plots was approximately $37.5 \%$ (average for years 2008 and 2009) of the applied $\mathrm{N}$ and leaching losses were greater in this plot due to lower $\mathrm{N}$ use efficiency by the pasture roots.

Table 11: Components of $\mathrm{N}$ balance in a $200 \mathrm{~cm}$ depth soil of the pasture field during the years 2008 and 2009

\begin{tabular}{|c|c|c|c|c|c|c|c|c|}
\hline & & $\begin{array}{c}\text { Initial } \mathbf{N} \\
\mathbf{I}\end{array}$ & $\begin{array}{c}\text { Residual } \\
\text { forage } \\
\text { F }\end{array}$ & $\begin{array}{l}\text { Manure } \\
\text { applied }\end{array}$ & $\begin{array}{c}\text { Cattle } \\
\text { deposition } \\
\mathbf{b}\end{array}$ & $\begin{array}{c}\mathrm{N} \\
\text { Leaching }\end{array}$ & $\begin{array}{l}\text { Crop N } \\
\text { Uptake }\end{array}$ & $\begin{array}{c}\text { N available } \\
\text { for next } \\
\text { year } \\
\text { d }\end{array}$ \\
\hline & & $\left(\mathrm{kg} \mathrm{ha}^{-1}\right)$ & $\left(\mathrm{kg} \mathrm{ha}^{-1}\right)$ & $\left(\mathrm{kg} \mathrm{ha}^{-1}\right)$ & $\left(\mathrm{kg} \mathrm{ha}^{-1}\right)$ & $\left(\mathrm{kg} \mathrm{ha}^{-1}\right)$ & $\left(\mathrm{kg} \mathrm{ha}^{-1}\right)$ & $\left(\mathrm{kg} \mathrm{ha}^{-1}\right)$ \\
\hline \multirow{2}{*}{$\begin{array}{l}\text { Control } \\
\text { Hayed }\end{array}$} & 2008 & 20.89 & 16.03 & - & - & 0.97 & 34.20 & 1.75 \\
\hline & 2009 & 22.12 & 12.61 & - & - & 1.03 & 34.40 & - \\
\hline \multirow{2}{*}{$\begin{array}{c}\text { Full } \\
\text { Hayed }\end{array}$} & 2008 & 26.22 & 56.07 & 119.00 & - & 0.94 & 131.30 & 69.05 \\
\hline & 2009 & 27.43 & 65.25 & 224.00 & - & 1.70 & 93.40 & 221.58 \\
\hline \multirow{2}{*}{$\begin{array}{l}\text { Control } \\
\text { grazed }\end{array}$} & 2008 & 24.89 & 32.12 & - & - & 0.80 & 19.01 & 37.20 \\
\hline & 2009 & 27.90 & 53.02 & - & - & 1.50 & 16.40 & 63.02 \\
\hline \multirow{2}{*}{$\begin{array}{c}\text { Full } \\
\text { grazed }\end{array}$} & 2008 & 28.90 & 132.37 & 119.00 & - & 10.70 & 53.20 & 216.37 \\
\hline & 2009 & 42.29 & 82.90 & 224.00 & - & 6.07 & 53.70 & 289.42 \\
\hline \multirow{2}{*}{$\begin{array}{c}\text { BEA } \\
\text { (control- } \\
\text { grazed) }\end{array}$} & 2008 & 67.80 & - & - & 1327 & 262.00 & - & 1132.80 \\
\hline & 2009 & 64.50 & - & - & 2040 & 429.00 & - & 835.50 \\
\hline \multirow{2}{*}{$\begin{array}{c}\text { BEA } \\
\text { (Full- } \\
\text { grazed) }\end{array}$} & 2008 & 83.60 & - & - & 291 & 191.00 & - & 1092.60 \\
\hline & 2009 & 99.10 & - & - & 4225 & 714.00 & - & 585.10 \\
\hline
\end{tabular}

I Sum of Initial $\mathrm{NH}_{4}{ }^{+}-\mathrm{N}$ and $\mathrm{NO}_{3}{ }^{-}-\mathrm{N}$ accumulated in the soil profile at the end of previous year (Table 4 and Coppi, 2012)

F $\mathrm{N}$ from the residual forage (uncut pasture) from previous year (Coppi, 2012)

b $\mathrm{N}$ added via cattle deposition on the bare earth areas(Coppi, 2012)

d $\mathrm{N}$ available for next year including accumulated and residual $\mathrm{N}$ associated with the current year 


\subsection{Regionalisation of nitrate leaching}

The gross nitrate leaching fluxes at 31 SSs as an average of years 2008 and 2009 were regionalised using Cokriging, and a mean value for the entire study area was obtained as 12.9 $\mathrm{kg} / \mathrm{ha}$ (Figure 25). The nitrate leaching flux inside BEAs of control-grazed plots averaged to $360 \mathrm{~kg} / \mathrm{ha}$ whereas in full-grazed plots its value averaged to $925 \mathrm{~kg} / \mathrm{ha}$ for both years. BEAs had an (mathematical) effect on outside their specific site due to a high gradient of nitrate leaching flux on the boundaries of these areas (approx. 1:925) (Figure 25). However, it is very important to note that leaching flux was largest inside the bare earth areas and just outside the boundary of bare earth area, the flux reduced significantly e.g. it was about 925 $\mathrm{kg} / \mathrm{ha}$ inside BEA of plot 11 and reduced to $110-300 \mathrm{~kg} / \mathrm{ha} 25 \mathrm{~m}$ away from boundary and further reduced to $8-15 \mathrm{~kg} / \mathrm{ha}$ when measured about $50 \mathrm{~m}$ away (Figure 27).

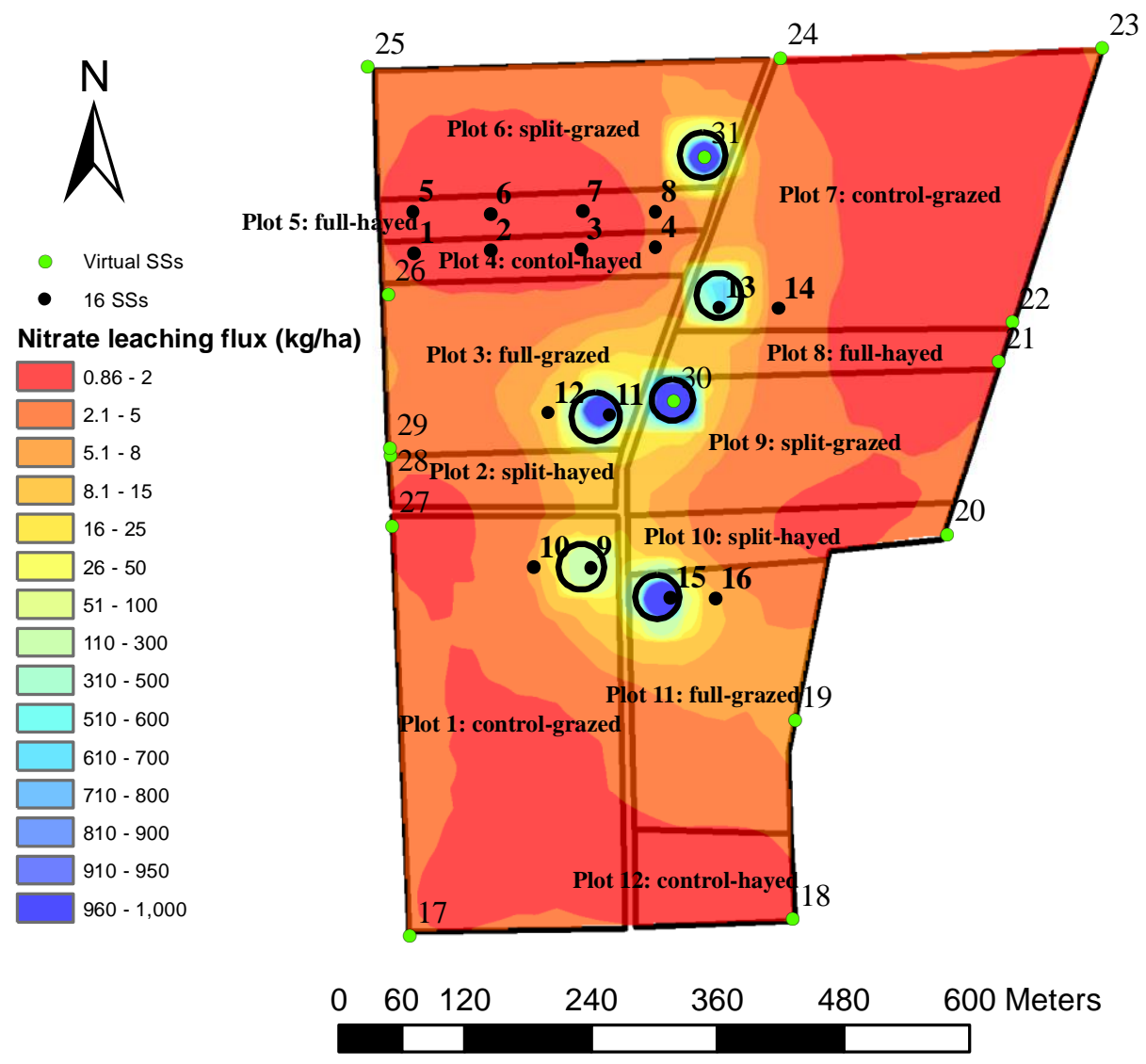

Figure 25: Nitrate leaching fluxes across the study area regionalised using Cokriging (average leaching rate: $12.9 \mathrm{~kg} / \mathrm{ha} /$ year) 
The study area separated into two categories: the red area that remained unaffected from nitrate excretion by beef cattle and leaching flux in this area was below $10 \mathrm{~kg} / \mathrm{ha} / \mathrm{year}$, the blue area which received most of the nitrate excreted by beef cattle (Figure 26, next page). The flux in the blue area was between about 11-1000 kg/ha/year. Furthermore, a comparison of average nitrate leaching fluxes resulting from different methods of interpolation was made. Using Cokriging, its value was averaged as $12.9 \mathrm{~kg} / \mathrm{ha}$ (Figure 25) whereas it was 274, 264 and $259 \mathrm{~kg} / \mathrm{ha}$ using Kriging (Figure 38, Appendix-C), Inverse Distance Weighing (IDW) (Figure 39, Appendix-C) and Natural Neighbors (NN) (Figure 40, Appendix-C) respectively. There was a significant difference in the value of leaching flux regionalised using different methods of interpolation. The chapter on discussion (Chapter 6) discusses the comparison of these methods and the best-fitted method that can be used to interpolate nitrate leaching fluxes for the La Broquerie case. 


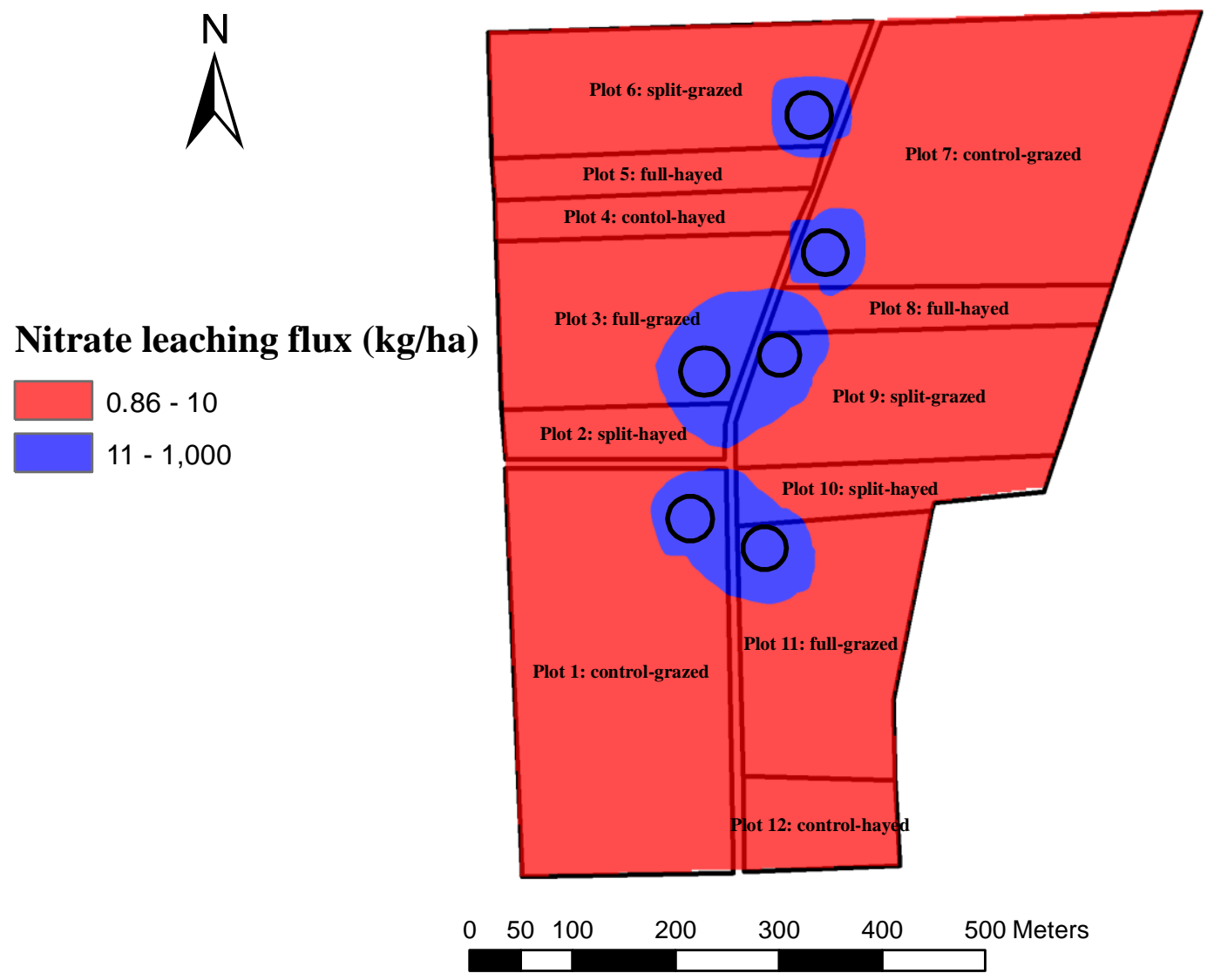

Figure 26: Nitrate leaching fluxes classified into two ranges, Blue area: affected by nitrate excreted by beef cattle (11-1000 kg/ha), red area: unaffected by nitrate excreted by cattle $(0.86-10 \mathrm{~kg} / \mathrm{ha})$

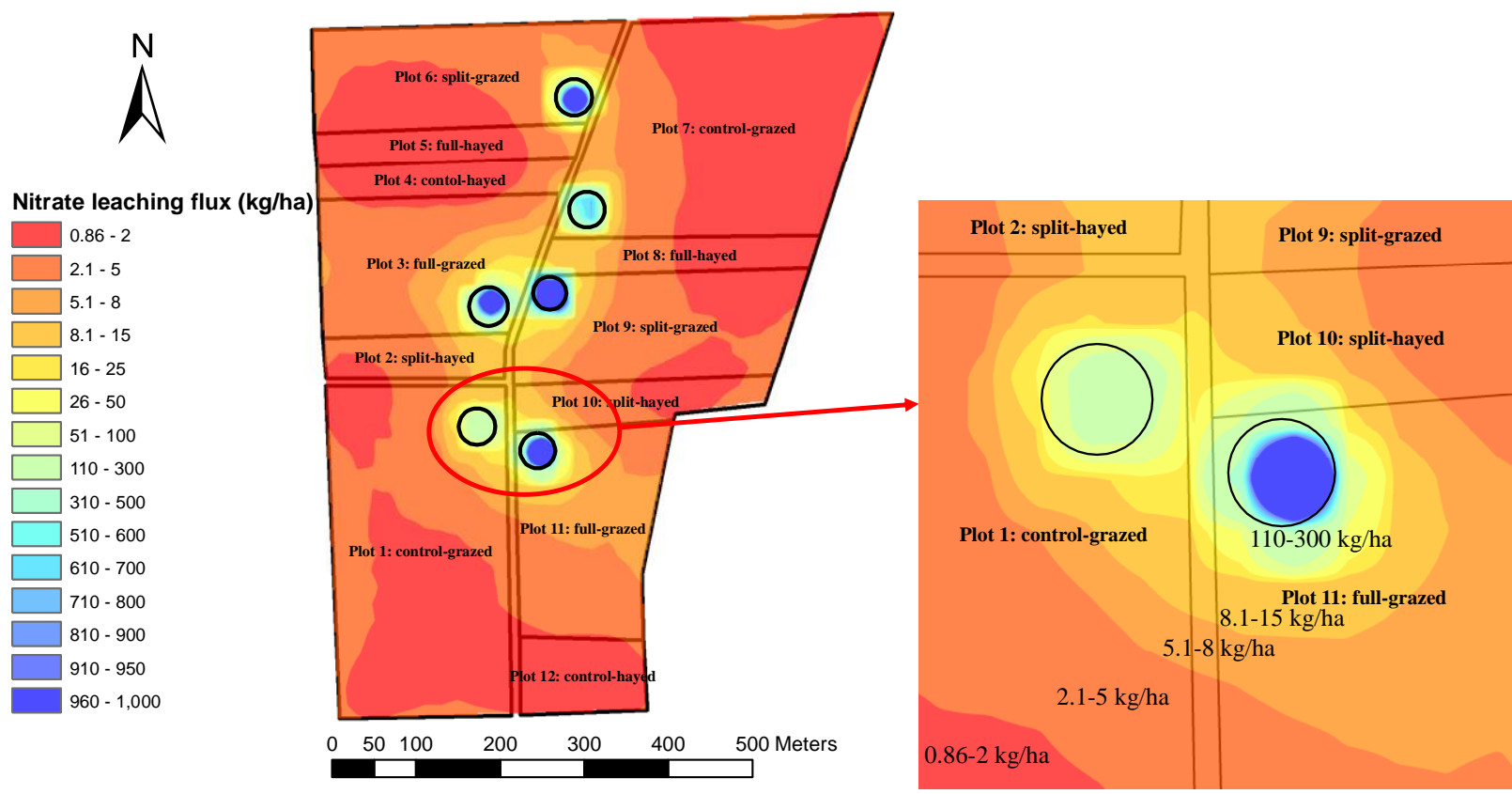

Figure 27: Nitrate leaching flux just outside the boundary of BEAs in plot 1 and plot 11 


\section{Chapter 6: Discussion}

The overall error in simulated soil moisture content based on the observed values was between 0.6 to $5 \%$ as expressed by RMSE and between 0.39 and 0.99 , expressed by NSE. The mean error (ME) was nearly equal to 0 in almost all simulations. Overall, the NSE and ME verified a good agreement between the simulated and observed soil moisture values. The temporal variations in soil moisture content were based on spring snowmelt and precipitation events throughout the year. It was observed that soil moisture content increased in the year 2009 due heavy precipitation events.

The sensitivity analysis was carried out to check the robustness of simulated recharge and nitrate leaching. The most sensitive parameter to the variations in soil moisture content was $n$. The changes in recharge as a result of changes in VGM parameters were always less than 5\% on a point scale (Figure 28), which proves the robustness of model in terms of recharge estimation. The estimated recharge using the VGM parameters directly derived from PTF was $4 \%$ and $3.6 \%$ larger than that after calibration for 2008 and 2009 respectively and verified the low sensitivity of the model output to the VGM parameters. Changing Ks to a larger scale $(\mathrm{Ks} * 2, \mathrm{Ks} / 2, \mathrm{Ks} * 4, \mathrm{Ks} / 4)$ accounted for soil heterogeneity and thus its impact on recharge. Changing $\mathrm{Ks}$ to $\mathrm{Ks} * 2, \mathrm{Ks} / 2, \mathrm{Ks}^{*} 4, \mathrm{Ks} / 4$ resulted in differences of recharge up to $10 \%$ which proved its low sensitivity to the groundwater recharge (Figure 28). 

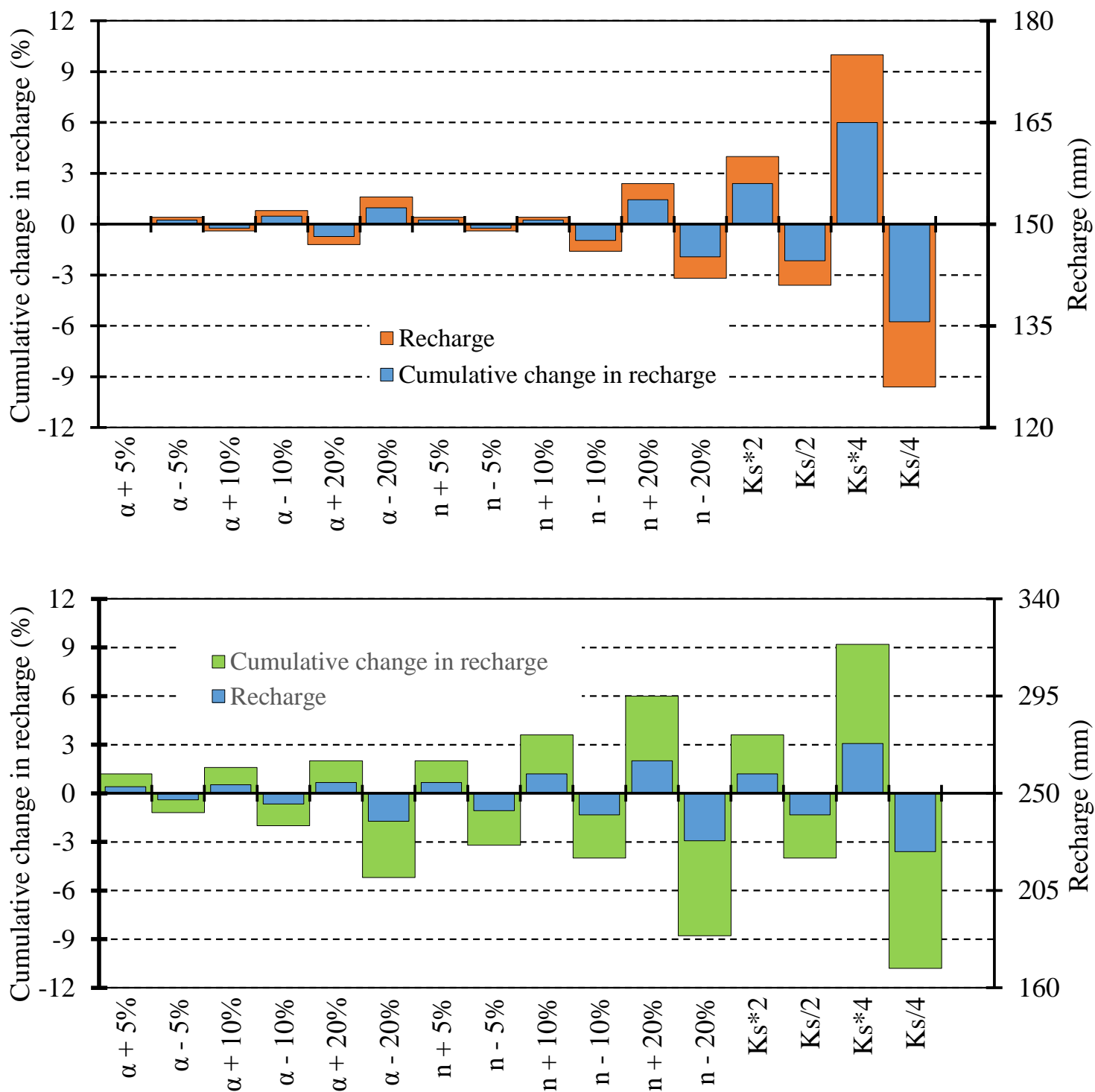

Figure 28: Changes in cumulative recharge for the year (a) 2008 and (b) 2009 as a result of changes in VGM parameter for SS-3

On an average, the recharge was estimated as $156.5 \mathrm{~mm}$ and $253.5 \mathrm{~mm}$ for the years 2008 and 2009 respectively. It was observed that most of the recharge, $42 \mathrm{~mm}$ out of $150 \mathrm{~mm}$ (about 28\%), occurred during the snow-melt period of the year 2008 from April $11^{\text {th }}$ to April $30^{\text {th }}$ (Figure 29) for SS-3. Similar recharge values were observed for other SSs. These findings agree with the rise in soil moisture content that was also observed after the snowmelt, and the precipitation events occurred throughout the year (Figure 6 and Figure 12 for temporal variations in soil moisture at $15 \mathrm{~cm}$ depth of SS-3). The increase in soil moisture content after precipitation or snowmelt events was mainly observed in the top layer of soil. At 
$75 \mathrm{~cm}$ and depths below, soil moisture was observed to be constant with time mainly due to the fact that root density decreases with increasing depth which leads to a lesser effect of evapotranspiration (Figure 12 for daily soil moisture at $75 \mathrm{~cm}$ depth of SS-3). Even after the precipitation events, the soil moisture at lower depths (e.g. at $75 \mathrm{~cm}$, Figure 12) did not change significantly with time which can be explained as (a) the upper soil layers (up to 60 cm depth) were of low hydraulic conductivity and had more water retention capacity due to the presence of loamy material (b) delayed change in soil moisture due to increased time of travel of the infiltrating water to the lower depths. It can also be observed that for SS-3 (layer $3,60-90 \mathrm{~cm}$ ), the value of parameter $n$ changed significantly from 2.85 to 5 and for SS-2 (layer 3, 60-90 cm), it changed from 2.85 to 4.55 after calibration. These changes can be considered to be associated with high stone content in the soil layers due to which the soil moisture was subjected to faster drainage and the resulting shape of relation between soil moisture content and time showed high fluctuations during the heavy precipitation events. The parameter $n$ in the VGM parameterization defines the steepness of the soil water retention curve between saturation and permanent wilting point. An increasing $n$ results into a stronger reduction of soil water with increasing suction. Thus, soil water percolate easier downwards.

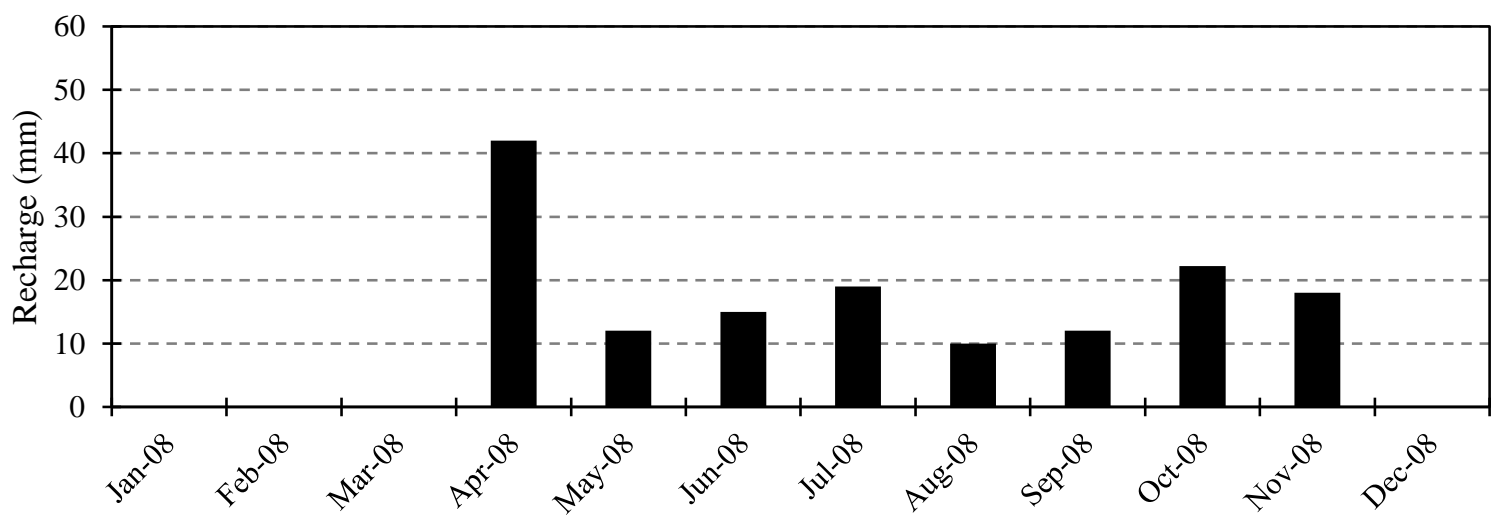

Figure 29: Monthly simulated recharge ( $\mathrm{mm})$ in 2008 
The water flow within the vadose zone is driven by the soil moisture (Holländer et al., 2016). So a good agreement between the observed and simulated soil moisture as expressed by overall RMSE of 0.7 - 5\%, NSE of 0.39 - 0.99 and approximately ' 0 ' ME were the basis of robust recharge estimation by the chosen method.

Soil freezing and thawing processes were not simulated with the standard HYDRUS-1D code. Therefore, the soil moisture content at different depths was only calibrated for periods from early spring (after the snowmelt) to the early winter (before the soil freezing). The nonaccommodation of soil freezing and thawing processes in model simulations was one of the major limitation of this research since these processes are very important to evaluate solute redistribution, water balance, and snowmelt infiltration correctly in the frozen soils (Saito et al., 2008). This disadvantage was clearly observed while calculating the monthly water balance for both years of study (2008 and 2009). The monthly water balance, shown in table 8 showed that there was negligible evapotranspiration in the winter months (NovemberMarch). As the standard code of HYDRUS 1-D was not able to simulate soil freezing and thawing, water fluxes in the form of evapotranspiration were observed in the modeling results (e.g. evapotranspiration of $2.2 \mathrm{~mm}$ in March 2008 and $10.2 \mathrm{~mm}$ in March 2009). Overall, there was a surplus of $29.6 \mathrm{~mm}$ and a deficit of $17 \mathrm{~mm}$ water observed in the soil profile for years 2008 and 2009 respectively.

The performance of the model in simulating the transport of nitrate in the soil profile as expressed by RMSE between $0.023 \mathrm{mg} \mathrm{L}^{-1}$ and $5.12 \mathrm{mg} \mathrm{L}^{-1}$, ME between $-1.03 \mathrm{mg} \mathrm{L}^{-1}$ and $1.05 \mathrm{mg} \mathrm{L}^{-1}$, NSE between 0.66 and 0.96 and $\mathrm{r}^{2}$ between 0.7 and 0.97 is shown in table 10 . The solute transport parameters obtained after calibration, $\mathrm{K}_{\mathrm{D}}\left(1.5-4.5 \mathrm{~cm}^{3} \mathrm{~g}^{-1}\right)$ and $\mu_{\mathrm{w}}(0.1-$ 0.7 day $^{-1}$ ) (table 9), were lying within the range of values reported in the literature. Ranjbar and Jalali (2013) mentioned in their study that ammonium adsorption increased linearly with the increased amounts of $\mathrm{NH}_{4}+$ added to the soil and hence the adsorption coefficient, $\mathrm{K}_{\mathrm{D}}$ 
which varied between 1.438 to $4.474 \mathrm{~cm}^{3} \mathrm{~g}^{-1}$. Another study conducted by Boatman and Murray (1982) reported the $\mathrm{K}_{\mathrm{D}}$ range from 2.7 to $5.8 \mathrm{~cm}^{3} \mathrm{~g}^{-1}$ on marine sediments. The first order decay coefficient, $\mu_{\mathrm{w}}$ was lying within the range reported in the literature as $0.02-0.5$ day $^{-1}$ by Lotse et al. (1992) and $0.24-0.72$ day $^{-1}$ were reported by Misra et al. (1974).

The sensitivity analysis of VGM parameters on nitrate leaching showed a maximum increase in nitrate leaching flux by $12.5 \%$ on decreasing $\alpha$ by $20 \%$ whereas the flux decreased by $6.95 \%$ when $\alpha$ was increased by $20 \%$. Parameter $n$ was the least sensitive parameter to nitrate leaching. The model was considered to be robust considering such range of variations in the nitrate leaching fluxes on changing VGM parameters.

The concentration of ammonium in groundwater was always observed to be less than $0.2 \mathrm{mg}$ $\mathrm{L}^{-1}$. So the model was considered to be calibrated if the simulated concentration of ammonium in groundwater was less than $0.2 \mathrm{mg} \mathrm{L}^{-1}$ at all time periods. Nitrate concentrations in groundwater in control and full-hayed plots averaged to be less than $1 \mathrm{mg}$ $\mathrm{L}^{-1}$ throughout the sampling campaign. Thus, the accumulation of nitrate in groundwater was generally not a concern with grass harvest by haying. The application of manure with greater than $\mathrm{N}$ requirement in 2009 did not increase nitrate concentration in groundwater (Figure 16). Therefore, it can be stated that nitrate concentration in groundwater was generally unaffected by the application of manure in hay treatment plots. Di and Cameron (2002) also reported a low concern for nitrate leaching in cut (hay) grasslands subjected up to $400 \mathrm{~kg} \mathrm{~N} \mathrm{ha}^{-1}$ especially when applications are made during spring when air temperatures are low.

Nitrogen stored in the soil for control-hay plot was about $14-15 \mathrm{~kg} \mathrm{ha}^{-1}$ for both years of study whereas the stored $\mathrm{N}$ in full-hayed plots was about $36.7 \mathrm{~kg} \mathrm{ha}^{-1}$ in 2008 and $178.9 \mathrm{~kg}$ $\mathrm{ha}^{-1}$ in 2009 due to spring manure applications in both years. The results suggested that the 
roots of pasture grass intercepted most of the nitrate and thereby prevented its leaching to groundwater.

Trends in groundwater nitrate concentrations in grazed plots varied with time among different manure treatment combinations. Since control-grazed plots did not receive any slurry throughout the study period, the simulated and observed groundwater nitrate concentrations were always below $1 \mathrm{mg} \mathrm{NO}-\mathrm{N} \mathrm{L}^{-1}$ in these plots whereas in full-grazed plots, the concentrations varied between 1-7 mg NO $3-\mathrm{N} \mathrm{L}^{-1} \mathrm{NO}_{3}-\mathrm{N}$ for both years of study. Overall, the results indicated that for all the treatment plots including control-hayed, full-hayed, controlgrazed and full-grazed, the groundwater nitrate concentrations were always below the drinking water threshold of $10 \mathrm{mg} \mathrm{NO}-\mathrm{N} \mathrm{L}^{-1}$.

The areas which posed a risk to nitrate contamination of groundwater were the BEAs. The observed and simulated results showed that the groundwater nitrate concentrations in BEAs of both control-grazed and full-grazed plots were consistently higher than $10 \mathrm{mg} \mathrm{NO} \mathrm{NO}_{3} \mathrm{~N} \mathrm{~L}^{-1}$ (Figure 17 and Figure 19). The $\mathrm{N}$ accumulated in soil through deposition of urine and feces was leached to the groundwater during these events. Furthermore, in BEAs, there was no plant uptake of $\mathrm{N}$, promoting the leaching losses.

Overall, the cumulative nitrate leaching fluxes for control-hayed, full-hayed and controlgrazed plots were below $2 \mathrm{~kg} \mathrm{NO}_{3}-\mathrm{N} \mathrm{ha}^{-1}$ for both years (Figure 22). However, for fullgrazed plots, the cumulative nitrate leaching flux was about $11 \mathrm{~kg} \mathrm{NO}_{3}-\mathrm{N} \mathrm{ha}^{-1}$ and $6 \mathrm{~kg} \mathrm{NO}_{3}-$ $\mathrm{N} \mathrm{ha}^{-1}$ for 2008 and 2009 respectively (Figure 22). The $\mathrm{N}$ leaching fluxes for all the plots showed a stepped increasing trend. This trend can be explained on the basis of snowmelt and precipitation events, especially in 2009 when due to heavy precipitation, this kind of trend in cumulative leaching fluxes was observed (Figure 22 and Figure 23). 
The cumulative leaching fluxes in BEAs were about 100 times larger than those in grassed areas. Also, these fluxes were larger in BEAs of full-grazed plots as compared to the BEAs in control-grazed plots. This was mainly due to the fact that cattle spent more time in full-grazed plots before they were removed from the plot due to the minimum requirement of biomass. Overall, these results suggested a concern for nitrate leaching to the groundwater in BEAs. The ammonium leaching fluxes were always below $1 \mathrm{~kg} \mathrm{NH}_{4}^{+}-\mathrm{N}$ ha ${ }^{-1}$ since model simulations showed that all of the available ammonium was quickly converted to nitrate by the process of nitrification.

Overall, HYDRUS-1D simulated reasonable results for both water flow and nitrate transport processes occurring in the study area for the years 2008 and 2009. It can be considered as a suitable and a reliable tool for estimating recharge and nitrate leaching on pasture fields of South-Western Manitoba subjected to the application of liquid hog manure under the continental climatic conditions.

Cokriging allowed considering the cross-correlation of nitrate leaching with the application of manure. The other methods of interpolation such as Kriging, Natural Neighbor, and Inverse Distance Weighing did not allow the cross-correlation between two parameters. The average leaching flux determined using Cokriging was $12.9 \mathrm{~kg} / \mathrm{ha}$ (Figure 25) whereas it was 274, 264 and 259 kg/ha using Kriging (Figure 38, Appendix-C), Inverse Distance Weighing (IDW) (Figure 39, Appendix-C) and Natural Neighbors (NN) (Figure 40, Appendix-C) respectively. Since the observed data on nitrate leaching fluxes were not available, it was expected that similar plot types would have same values of nitrate leaching fluxes. For example, the leaching fluxes in control treatment plots were always below $1 \mathrm{~kg} / \mathrm{ha}$ and for full treatment plots, they were about $10 \mathrm{~kg} / \mathrm{ha}$, as obtained by physically obtained modeling. It was assumed that these fluxes were strictly dependent on the plot type, manure application, and forage removal treatments. The BEAs had high fluxes only within their boundaries and 
just outside their boundaries, the fluxes reduced significantly. Very high average leaching fluxes of nitrate were obtained using Kriging, IDW, and NN since the interpolation using these methods was done considering only one variable of interest (leaching fluxes).

The regionalisation results (Figure 25 and Figure 27) showed the effect of BEAs outside their boundaries due to a high gradient of nitrate leaching flux on the boundaries of these areas (approx. 1:925). This can be justified on the basis that beef cattle were mostly loafing inside the perimeter of BEAs where they excreted most of the nitrogen ingested via grazing and also in some areas outside the perimeter to travel from one BEA to other. Therefore, the flux was greater than $10 \mathrm{~kg} / \mathrm{ha}$ in some areas outside the BEAs as well. Regionalisation results showed the risk of nitrate leaching only in BEAs and areas around them (Figure 26, blue region). However, the rest of the study area (Figure 26, red region) was found not to be prone to nitrate leaching. Furthermore, there was another attempt made to figure out what would be the situation if there were no BEAs in the study site (Figure 30). The average nitrate leaching flux for the entire study area under this scenario was estimated as $3.6 \mathrm{~kg} / \mathrm{ha}$. 


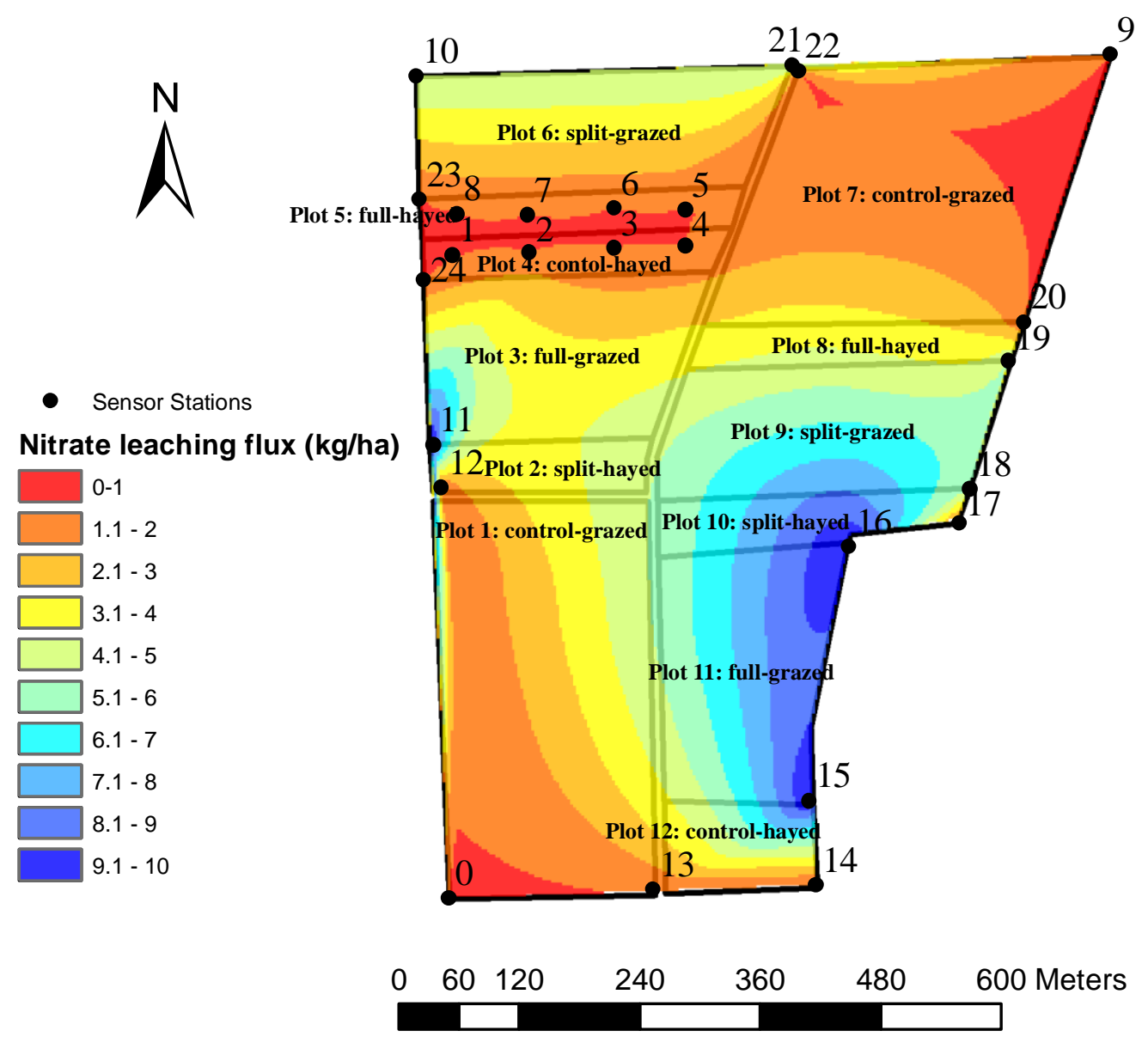

Figure 30: Nitrate leaching in a scenario when the study site consisted of no BEAs. Average flux: $3.6 \mathrm{~kg} / \mathrm{ha}$

As explained earlier, the focus of Best Management Practices (BMPs) is to achieve an efficient use of available resources (e.g. hog manure) such that the environmental risks concerned with them being unused are controlled. In this study, it was found that only Bare Earth Areas were at risk of nitrate leaching and groundwater contamination. The Best Management Practice for the study area would be to adopt haying as a forage harvesting technique since the nitrate leaching fluxes were minimum in plots where haying was adopted as a harvesting treatment. The removal of $\mathrm{N}$ by haying would not allow its accumulation in soil and will ultimately prevent its leaching to the groundwater.

Another concern which can be subjected as the area of further research relating this study site is increase in the production of beef cattle at the study site. If the cattle production at study 
site increases, more number of cattle would be required to be sent to the study area for grazing purposes, ultimately increasing the number and size of Bare Earth Areas which would lead to a greater risk of nitrate leaching and contamination of groundwater by nitrate. 


\section{Conclusions}

This research showed how the daily meteorological data and soil physical properties were used to simulate daily soil moisture and yearly recharge values at different SSs of the study area. The model was calibrated on the basis of daily soil moisture content at different depths and was found to simulate robust recharge values. The low sensitivity of groundwater recharge on the VGM parameters proved the robustness of the adapted method.

Simulation results suggested that two years of liquid hog manure application to the hay pasture on a coarse sand soil did not cause the significant accumulation of nitrate in the shallow groundwater. Even during the snowmelt and heavy precipitation events, the shallow groundwater nitrate concentrations never exceeded $10 \mathrm{mg} \mathrm{NO}-\mathrm{N} \mathrm{L}^{-1}$. This was likely due to the uptake of nitrate by plant roots. Following the same manure application treatments in the grazed pasture plots, the concentration of nitrate in groundwater was not an environmental concern even though it occasionally rose closer to the drinking water threshold. In contrast, nitrate concentrations above the drinking water threshold were simulated in BEAs throughout the vegetation period. Leaching of large amounts of nitrate to the groundwater occurred in these areas.

HYDRUS-1D simulated the soil moisture content and groundwater nitrate concentrations with a good agreement with the observed values. On the other hand, the standard HYDRUS1D code was not able to simulate freezing and thawing of soil which was the major drawback of this research. Cokriging allowed the cross-correlation of nitrate leaching with the application of manure and improved the prediction of resulting map. Regionalisation results suggested that BEAs and some areas around their periphery were under the concern of nitrate leaching. 
Overall, HYDRUS-1D can be considered as a useful tool in quantifying the recharge and nitrate leaching estimates for pasture fields subjected to continental climates, and Cokriging can be considered as a reliable method for a study site where cross-correlations between variables are important to consider carrying out interpolation. 


\section{References}

Addiscott, T.M., Benjamin, N., 2004. Nitrate and human health. Soil Use and Management, 20(2): 98-104.

Ahmadi, S.H., Sedghamiz, A., 2008. Application and evaluation of kriging and cokriging methods on groundwater depth mapping. Environmental Monitoring and Assessment, 138(1): 357-368.

Allen, R.G., Pereira, L.S., Raes, D., Smith, M., 1998. Crop evapotranspiration. Guidelines for computing crop water requirements. Irrigation and Drainage Paper, 56. FAO, Rome, $300 \mathrm{pp}$.

Bartier, P.M., Keller, C.P., 1996. Multivariate interpolation to incorporate thematic surface data using inverse distance weighting (IDW). Computers \& Geosciences, 22(7): 795799.

Bayraktar, H., Turalioglu, F.S., 2005. A Kriging-based approach for locating a sampling site - in the assessment of air quality. Stochastic Environmental Research and Risk Assessment, 19(4): 301-305.

Boatman, C.D., Murray, J.W., 1982. Modeling exchangeable NH4+ adsorption in marine sediments: Process and controls of adsorption1,2. Limnology and Oceanography, 27(1): 99-110.

Brisson, Y., 2014. The changing face of the Canadian hog industry. Canada, S., http://www.statcan.gc.ca/pub/96-325-x/2014001/article/14027-eng.pdf, last accessed: 13 Nov, 2016

Brooks, R.H., Corey, A.T., 1964. Hydraulic properties of porous media, 3. Hydrology papers, Colorado State University, Fort Collins, Colorado.

Bruce, J.P., 2009. The sustainable management of groundwater in Canada report of the Expert Panel on Groundwater. 
Burton, D.L., Ryan, M.C., Inc, M.H.P.E.C., 2000. Environmental fate of nitrate in the Assiniboine Delta Aquifer. LRCS Land Resource Consulting Services.

Cabrera, M.L., Gordillo, R.M., 1995. Nitrogen release from land-applied animal manures, Georgia Water Resources Conference, The University of Georgia.

Carpenter, S.R., Caraco, N.F., Correll, D.L., Howarth, R.W., Sharpley, A.N., Smith, V.H., 1998. Nonpoint pollution of surface waters with phosphorous and nitrogen. Ecological Applications, 8(3): 559-568.

Chilès, J.P., Delfiner, P., 1999. Geostatistics: modeling spatial uncertainty. Wiley.

Comly, H.H., 1945. Cyanosis in infants caused by nitrates in well water. Journal of the American Medical Association, 129(2): 112-116.

Cooperband, L.R., Good, L.W., 2002. Biogenic phosphate minerals in manure: Implications for phosphorus loss to surface waters. Environmental Science \& Technology, 36(23): 5075-5082.

Coppi, L., 2012. Nitrogen and phosphorus in soil and groundwater following repeated nitrogen-based swine slurry applications to a tame grassland on coarse textured soil. Dissertation Thesis, University of Manitoba, Winnipeg, Manitoba, Canada, 226 pp.

Czitrom, V., 1999. One-factor-at-a-time versus designed experiments. American Statistician, 53(2): 126-131.

Dahan, O., Babad, A., Lazarovitch, N., Russak, E.E., Kurtzman, D., 2014. Nitrate leaching from intensive organic farms to groundwater. Hydrol. Earth Syst. Sci., 18(1): 333341.

Dahlin, A.S., Emanuelsson, U., McAdam, J.H., 2005. Nutrient management in low input grazing-based systems of meat production. Soil Use and Management, 21(1): 122131. 
Di, H.J., Cameron, K.C., 2002. Nitrate leaching in temperate agroecosystems: sources, factors and mitigating strategies. Nutrient Cycling in Agroecosystems, 64(3): 237256.

Durner, W., 1994. Hydraulic conductivity estimation for soils with heterogeneous pore structure. Water Resources Research, 30(2): 211-223.

Environment Canada, 2009. Groundwater. https://www.ec.gc.ca/eauwater/default.asp?lang=En\&n=300688DC-1, last accessed: 3 Nov, 2016.

Environment Canada, 2010. Groundwater Contamination. https://www.ec.gc.ca/eauwater/default.asp?lang=En\&n=6A7FB7B2-1, last accessed: 3 Nov, 2016.

Environment Canada, 2013. Groundwater. https://www.ec.gc.ca/eauwater/default.asp?lang=En\&n=300688DC-1, last accessed: 17 Sept, 2016.

EPA, 2015. Nutrient Pollution. http://www2.epa.gov/nutrientpollution/sources-and-solutions, last accessed:

ESRI, 2014. ArcGIS Desktop: Release 10.2. Environmental Systems Research Institute., Redlands, CA.

Evers, S., Fletcher, S., Ward, R., Harris, B., Oliver, M., Lovett, A., Lake, I., Hiscock, K., 2004. A strategy for groundwater protection from nitrate leaching using spatial and geostatistical analyses. In: Sanchez-Vila, X., Carrera, J., Gómez-Hernández, J. (Eds.), geoENV IV - Geostatistics for Environmental Applications. Quantitative Geology and Geostatistics. Springer Netherlands, pp. 506-507.

Feddes, R.A., Kowalik, P.J., Zaradny, H., 1978. Simulation of field water use and crop yield. Wiley.

Flaten, D., Snelgrove, K., Halket, I., Buckley, K., Grant Penn, Akinremi, W., Wiebe, B., Tyrchniewicz, E., 2003. Acceptable phosphorus concentrations in soils and impact on the risk of phosphorus transfer from manure amended soils to surface waters. A 
review of literature for the Manitoba Livestock Manure Management Initiative, Department of Soil Sciene, University of Manitoba and AAFC Brandon Research Centre.

Fredlund, D.G., Xing, A., 1994. Equations for the soil-water characteristic curve. Canadian Geotechnical Journal, 31(4): 521-532.

Frost, L., 2006. A regional groundwater sampling program of private well water in Manitoba: Bacteria and nitrate findings. Manitoba Water Stewardship Report No. 2006-02.

Gelhar, L.W., Welty, C., Rehfeldt, K.R., 1992. A critical review of data on field-scale dispersion in aquifers. Water Resources Research, 28(7): 1955-1974.

Globe and Mail, 2008. Nitrates killed thousands of PEI fish, officials say. http://www.theglobeandmail.com/news/national/nitrates-killed-thousands-of-pei-fishofficials-say/article25580858/, last accessed: 18 Sept, 2016.

Goovaerts, P., 2000. Geostatistical approaches for incorporating elevation into the spatial interpolation of rainfall. Journal of Hydrology, 228(1-2): 113-129.

Government of Manitoba, 2008. Spring 2008 flood outlook identifies potential for flooding as relatively low for most of $\quad$ Manitoba. http://news.gov.mb.ca/news/print,index.html?item=3175, last accessed: March 10, 2017

Hanson, B.R., Šimůnek, J., Hopmans, J.W., 2006. Evaluation of urea-ammonium-nitrate fertigation with drip irrigation using numerical modeling. Agricultural Water Management, 86(1-2): 102-113.

Harker, L., Hutcheon, I., Mayer, B., 2015. Use of major ion and stable isotope geochemistry to delineate natural and anthropogenic sources of nitrate and sulfate in the Kettle River Basin, British Columbia, Canada. Comptes Rendus Geoscience, 347(7-8): 338347. 
Haygarth, P.M., Jarvis, S.C., 2002. Agriculture, hydrology, and water quality. CABI.

Health Canada, 2013. Guidelines for Canadian drinking water quality: Guideline technical document: Nitrate and nitrite.

Healy, R.W., 2010. Estimating Groundwater Recharge, 3. Cambridge Univ. Press, U.K., 66$69 \mathrm{pp}$.

Holländer, H.M., Wang, Z., Assefa, K.A., Woodbury, A.D., 2016. Improved recharge estimation from portable, low-cost weather stations. Groundwater, 54(2): 243-254.

ISAAP, 2015. Nitrogen Use Efficient Biotech Cropslast accessed: 16 September.

Jacobs, J., Siddoway, J., 2007. Tame pasture grass and legume species and grazing guidelines. National Resources Conservation Service, United States Department of Agriculture.

Jarvis, N.J., 1989. A simple empirical model of root water uptake. Journal of Hydrology, 107(1): 57-72.

Jones, S.B., Wraith, J.M., Or, D., 2002. Time domain reflectometry measurement principles and applications. Hydrological Processes, 16(1): 141-153.

Journel, A.G., 1989. Fundamentals of geostatistics in five lessons. American Geophysical Union.

Kosugi, K.i., 1996. Lognormal distribution model for unsaturated soil hydraulic properties. Water Resources Research, 32(9): 2697-2703.

Krige, D.G., Matheron, G., 1967. 2-Dimensional Weighted Moving Average Trend Surfaces for Ore Valuation. Journal of the South African Institute of Mining and Metallurgy, 67(12): 687-\&.

Land Resource Unit, 1999. Soils and Terrain: An introduction to the land resource. Rural Municipality of La Broquerie. Information Bulletin 98-24, B.R.C., Research Branch, Agriculture and Agri-Food Canada, last accessed: 
Lee, S.J., Ma, K.F., Chen, H.W., 2006. Three-dimensional dense strong motion waveform inversion for the rupture process of the 1999 Chi-Chi, Taiwan, earthquake. J. Geophys. Res., 111(B11308).

Lefebvre, A., W. Eilers, et B. Chunn, 2005. Environmental sustainability of Canadian agriculture: Agri-Environmental indicator report series report \#2.

Liu, H., Zhang, R., Li, Y., 2013a. Sensitivity analysis of reference evapotranspiration (ETo) to climate change in Beijing, China. Desalination and Water Treatment, 52(13-15): 2799-2804.

Liu, X., Sun, S., Ji, P., Šimůnek, J., 2013b. Evaluation of historical nitrate sources in groundwater and impact of current irrigation practices on groundwater quality. Hydrological Sciences Journal, 58(1): 198-212.

Lorenz, D.L., Delin, G.N., 2007. A regression model to estimate regional ground-water recharge in Minnesota. Ground Water, 45(2): 13.

Lotse, E.G., Jabro, J.D., Simmons, K.E., Baker, D.E., 1992. Simulation of nitrogen dynamics and leaching from arable soils. Journal of Contaminant Hydrology, 10(3): 183-196.

Manitoba Agriculture, 2009. Manure nutrients and their behaviour in soilhttp://www.gov.mb.ca/agriculture/environment/nutrientmanagement/pubs/mmf_manurenutribehaviour_factsheet.pdf, last accessed: 26 Oct, 2016

Manitoba Agriculture, 2013. Effects of manure and fertilizer on soil fertility and soil qualityhttp://www.gov.mb.ca/agriculture/environment/nutrientmanagement/pubs/effects-of-manure $\% 20$-fertilizer-on $\% 20$ soil $\% 20$ fertilityquality.pdf, last accessed: 03 Nov, 2016 
Manitoba Agriculture, 2016. Industry Profile - tame hay (Alfalfa \& Timothy). https://www.gov.mb.ca/agriculture/crops/production/forages/industry-profile-tamehay-alfalfa-and-timothy.html, last accessed: 19/07/2016.

Marquardt, D.W., 1963. An algorithm for least-squares estimation of nonlinear parameters. Journal of the Society for Industrial and Applied Mathematics, 11(2): 431-441.

Matheron, G., 1967. Kriging or Polynomial Interpolation Procedures - a Contribution to Polemics in Mathematical Geology. Canadian Mining and Metallurgical Bulletin, 60(665): 1041-\&.

Misra, C., Nielsen, D.R., Biggar, J.W., 1974. Nitrogen transformations in soil during leaching: II. steady state nitrification and nitrate reduction. Soil Science Society of America Journal, 38: 294-299.

Mitas, L., Mitasova, H., 1999. Spatial interpolation. Geographical information systems: principles, techniques, management and applications, 1: 481-492.

Mualem, Y., 1976. A new model for predicting the hydraulic conductivity of unsaturated porous media. Water Resources Research, 12(3): 513-522.

Müller, Z.O., 1980. Feed from animal wastes: state of knowledge. Food and Agriculture Organization of the United Nations, FAO, Rome, pp. 189.

Nash, J.E., Sutcliffe, J.V., 1970. River flow forecasting through conceptual models part I A discussion of principles. Journal of Hydrology, 10(3): 282-290.

OECD, EUROSTAT, 2007. Gross nitrogen balances handbook.

Oostrom, M., Truex, M.J., Carroll, K.C., Chronister, G.B., 2013. Perched-water analysis related to deep vadose zone contaminant transport and impact to groundwater. Journal of Hydrology, 505: 228-239.

Papritz, A., Dubois, J.R., 1999. Mapping heavy metals in soil by (non-) linear kriging: an empirical validation. In: Gómez-Hernández, J., Soares, A., Froidevaux, R. (Eds.), 
geoENV II — geostatistics for environmental applications: proceedings of the second european conference on geostatistics for environmental applications held in Valencia, Spain, November 18-20, 1998. Springer Netherlands, Dordrecht, pp. 429-440.

Paradis, D., Vigneault, H., Lefebvre, R., Savard, M.M., Ballard, J.M., Qian, B., 2016. Groundwater nitrate concentration evolution under climate change and agricultural adaptation scenarios: Prince Edward Island, Canada. Earth Syst. Dynam., 7(1): 183202.

Piccini, C., Marchetti, A., Farina, R., Francaviglia, R., 2012. Application of indicator kriging to evaluate the probability of exceeding nitrate contamination thresholds. International Journal of Environmental Research, 6(4): 853-862.

Ranjan, R.S., Manokararajah, K., Sadaka, S.S., 2001. Develop a decision support system for land application of manure affecting the groundwater quality in Manitoba, University of Manitoba.

Ranjbar, F., Jalali, M., 2013. Measuring and modeling ammonium adsorption by calcareous soils. Environmental Monitoring and Assessment, 185(4): 3191-3199.

Ribaudo, M., Hansen, L., Livingston, M., Mosheim, R., Williamson, J., 2011. Nitrogen in agricultural systems: Implications for conservation policy, United States Department of Agriculture.

Richards, L.A., 1931. Capilary conduction of liquids through porous mediums. Physics, 1(5): 318-333.

Richmond, A., 2002. An alternative implementation of indicator kriging. Computers \& Geosciences, 28(4): 555-565.

Rudolph, D.L., Devlin, J.F., Bekeris, L., 2015. Challenges and a strategy for agricultural BMP monitoring and remediation of nitrate contamination in unconsolidated aquifers. Groundwater Monitoring \& Remediation, 35(1): 97-109. 
Saito, H., M. Sakai, N.T., J. Šimůnek, 2008. Proceedings of the third HYDRUS workshop. Dept. of Ecoregion Science, Tokyo University of Agriculture \& Technology, Fuchu Tokyo, Japan,.

Saso, J.K., 2009. Evaluating nitrate leaching potential for two different hydrological soil groups using a conservative tracer. M.sc. Thesis, The Faculty of Graduate Studies, The University of Guelph, 93 pp.

Schaap, M.G., Leij, F.J., Genuchten, M.T.V., 2001a. ROSETTA: a computer program for estimating soil hydraulic parameters with hierarchical pedotransfer functions. Journal of Hydrology.

Schaap, M.G., Leij, F.J., van Genuchten, M.T., 2001b. ROSETTA: A computer program for estimating soil hydraulic parameters with hierarchical pedotransfer functions. Journal of Hydrology, 251(3-4): 163-176.

Schindler, D.W., Dillon, P.J., Schreier, H., 2006. A review of anthropogenic sources of nitrogen and their effects on Canadian aquatic ecosystems. Biogeochemistry, 79(1): 25.

Shekofteh, H., Afyuni, M., Hajabbasi, M.A., Iversen, B.V., Nezamabadi-Pour, H., Abassi, F., Sheikholeslam, F., Shirani, H., 2013. Modeling of nitrate leaching from a potato field using HYDRUS-2D. Communications in Soil Science and Plant Analysis, 44(20): 2917-2931.

Sibson, R., 1981. A brief description of Natural Neighbour interpolation. In: Barnett, V. (Ed.), Interpreting multivariate data. John Wiley \& Sons, pp. 21-36.

Šimůnek, J., Genuchten, M.T.v., Šejna, M., 2012. Hydrus: Model use, calibration and validation. American Society of Agricultural and Biological Engineers ISSN 21510032, Vol. 55(4): 1261-1274. 
Simunek, J., van Genuchten, M.T., Šejna, M., 2008. Development and applications of the HYDRUS and STANMOD software packages and related codes. Vadose Zone Journal, 7(2): 587-600.

Sun, Y., Kang, S., Li, F., Zhang, L., 2009. Comparison of interpolation methods for depth to groundwater and its temporal and spatial variations in the Minqin oasis of northwest China. Environmental Modelling \& Software, 24(10): 1163-1170.

Tan, X., Shao, D., Gu, W., Liu, H., 2015. Field analysis of water and nitrogen fate in lowland paddy fields under different water managements using HYDRUS-1D. Agricultural Water Management, 150: 67-80.

Tonkin, M.J., Larson, S.P., 2002. Kriging water levels with a regional-linear and pointlogarithmic drift. Ground Water, 40(2): 185-193.

Unser, M., 1999. Splines: a perfect fit for signal and image processing. IEEE Signal Processing Magazine, 16(6): 22-38.

van Genuchten, M.T., 1980. A closed-form equation for predicting the hydraulic conductivity of unsaturated soils. Soil Science Society of America Journal, 44(5): 892-898.

Vogel, T., Cislerova, M., 1988. On the reliability of unsaturated hydraulic conductivity calculated from the moisture retention curve. Transport in Porous Media, 3(1): 1-15.

Walton, G., 1951. Survey of literature relating to infant methemoglobinemia due to nitratecontaminated water. American Journal of Public Health and the Nations Health, 41(8 Pt 1): 986-996.

Wang, H., Magesan, G.N., Bolan, N.S., 2004. An overview of the environmental effects of land application of farm effluents. New Zealand Journal of Agricultural Research, 47(4): 389-403.

Wang, Z., 2017. Spatial interpolation of improved groundwater recharge estimates on coarse textured soils, The University of Manitona. 
Williams, P.H., Haynes, R.J., 1990. Influence of improved pastures and grazing animals on nutrient cycling within New Zealand soils. New Zealand Journal of Ecology, 14: 4957.

Wilson, C., Undi, M., Tenuta, M., Wittenberg, K.M., Flaten, D., Krause, D.O., Entz, M.H., Holley, R., Ominski, K.H., 2010. Pasture productivity, cattle productivity and metabolic status following fertilization of a grassland with liquid hog manure: A three-year study. Canadian Journal of Animal Science, 90(2): 233-243.

Xiao, Y., Gu, X., Yin, S., Shao, J., Cui, Y., Zhang, Q., Niu, Y., 2016. Geostatistical interpolation model selection based on ArcGIS and spatio-temporal variability analysis of groundwater level in piedmont plains, northwest China. SpringerPlus, 5(1): 425.

Yalçin, E., 2005. Cokriging and its effect on the estimation precision. Journal of the Southern African Institute of Mining and Metallurgy, 105(4): 223-228.

Yao, L., Huo, Z., Feng, S., Mao, X., Kang, S., Chen, J., Xu, J., Steenhuis, T.S., 2014. Evaluation of spatial interpolation methods for groundwater level in an arid inland oasis, northwest China. Environmental Earth Sciences, 71(4): 1911-1924. 


\section{Appendix-A (Data)}

Appendix A.1:

Table 12: Manure characteristics (modified after Coppi, 2012)

\begin{tabular}{|c|c|c|c|c|c|c|}
\hline Timing & Fall 06 & $\begin{array}{c}\text { Spring } \\
07\end{array}$ & Fall 07 & $\begin{array}{c}\text { Spring } \\
08\end{array}$ & Fall 08 & $\begin{array}{c}\text { Spring } \\
09\end{array}$ \\
\hline Date of Application & $\begin{array}{c}\text { Octobe } \\
\text { r 3, } \\
2006\end{array}$ & $\begin{array}{c}\text { May 9, } \\
2007\end{array}$ & $\begin{array}{l}\text { October } \\
3,2007\end{array}$ & $\begin{array}{l}\text { May 5, } \\
2008\end{array}$ & $\begin{array}{l}\text { November } \\
6,2008\end{array}$ & $\begin{array}{l}\text { May } 20 \\
2008\end{array}$ \\
\hline $\mathrm{NH}_{3}\left(\mathrm{~kg} / \mathrm{m}^{3}\right)$ & 3.35 & 3.83 & 3.11 & 3.23 & 3.23 & 3.95 \\
\hline Moisture \% & 96.4 & 92.6 & 95.8 & 90.2 & 95.7 & 87.0 \\
\hline $\begin{array}{l}\text { Electrical Conductivity } \\
\text { (dS/m) }\end{array}$ & 28.9 & 26.6 & 22.0 & 18.0 & 18.6 & 9.0 \\
\hline $\mathbf{p H}$ & 7.6 & 7.3 & 7.1 & 6.9 & 11.0 & 5.8 \\
\hline $\begin{array}{c}\text { Ammonia (mg NH3-N / } \\
\text { L) }\end{array}$ & 3410 & 4118 & 3705 & 3746 & 3630 & 3575 \\
\hline Nitrate mg $\mathrm{NO}_{3}-\mathrm{N} / \mathrm{L}$ & 9.0 & 1.3 & 1.0 & 2.6 & 3.0 & 0.7 \\
\hline $\begin{array}{c}\text { Total N \% of Fresh } \\
\text { Weight }\end{array}$ & 0.49 & 0.53 & 0.51 & 0.58 & 0.52 & 0.64 \\
\hline $\begin{array}{c}\text { Organic N \% of Fresh } \\
\text { Weight }\end{array}$ & 0.15 & 0.12 & 0.14 & 0.20 & 0.16 & 0.28 \\
\hline
\end{tabular}

\section{Appendix A.2}

Table 13: Rates of manure application and amounts of nutrients applied per $\mathrm{m}^{2}$. Values for the split treatments in fall are standardized to rates for a full application treatment. In spring 2009 a double amount of manure (2x N crop removal rates) was applied (modified after

Coppi, 2012)

\begin{tabular}{|c|c|c|c|c|c|c|}
\hline Timing & fall 06 & spring 07 & fall 07 & $\begin{array}{c}\text { spring } \\
08\end{array}$ & fall 08 & $\begin{array}{c}\text { spring } \\
09\end{array}$ \\
\hline Date of Application & $\begin{array}{l}\text { 03-Oct- } \\
06\end{array}$ & $\begin{array}{l}\text { 09-May- } \\
07\end{array}$ & $\begin{array}{l}\text { 03-Oct- } \\
07\end{array}$ & $\begin{array}{l}\text { 05-May- } \\
08\end{array}$ & $\begin{array}{l}\text { 06-Nov- } \\
08\end{array}$ & $\begin{array}{l}\text { 20-May- } \\
08\end{array}$ \\
\hline Application Rate $1 / \mathbf{m}^{2}$ & 4.435 & 3.12 & 4.31409 & 3.615645 & 4.257055 & 6.661875 \\
\hline $\begin{array}{c}\text { Estimated Available N } \\
\text { applied } \mathrm{kg} \mathrm{N} / \mathrm{m}^{2}\end{array}$ & 0.012765 & 0.010434 & 0.01332 & 0.011766 & 0.013098 & 0.0222 \\
\hline $\begin{array}{c}\text { Total Nitrogen kg N / } \\
\text { m }^{2}\end{array}$ & 0.021201 & 0.016317 & 0.021645 & 0.020535 & 0.021867 & 0.041847 \\
\hline
\end{tabular}


Table 14: Mean monthly air temperature and monthly rainfall for the growing seasons (April to October) from 2006 to 2009 and long term climate (mean temperature and rainfall) for the years 1971 to 2000 (Coppi, 2012).

\begin{tabular}{|c|c|c|c|c|c|c|c|c|c|c|}
\hline \multirow{2}{*}{$\frac{\text { Year }}{\text { Month }}$} & \multicolumn{2}{|c|}{-----2006----- } & \multicolumn{2}{|c|}{-----2007----- } & \multicolumn{2}{|c|}{-----2008----- } & \multicolumn{2}{|c|}{-----2009----- } & \multicolumn{2}{|c|}{ Long-term average } \\
\hline & $\begin{array}{l}\text { Mean } \\
\text { Temp } \\
\left({ }^{\circ} \mathrm{C}\right)\end{array}$ & $\begin{array}{l}\text { Rainfall } \\
(\mathrm{mm})\end{array}$ & $\begin{array}{l}\text { Mean } \\
\text { Temp } \\
\left({ }^{\circ} \mathrm{C}\right)\end{array}$ & $\begin{array}{l}\text { Rainfall } \\
(\mathrm{mm})\end{array}$ & $\begin{array}{l}\text { Mean } \\
\text { Temp } \\
\left({ }^{\circ} \mathrm{C}\right)\end{array}$ & $\begin{array}{l}\text { Rainfall } \\
(\mathrm{mm})\end{array}$ & $\begin{array}{l}\text { Mean } \\
\text { Temp } \\
{ }^{\circ} \mathrm{C}\end{array}$ & Rainfall & $\begin{array}{l}\text { Mean } \\
\text { Temp } \\
\left({ }^{\circ} \mathrm{C}\right)\end{array}$ & $\begin{array}{l}\text { Rainfall } \\
(\mathrm{mm})\end{array}$ \\
\hline April & 8.9 & 12 & 4.0 & 7 & 3.2 & 21 & 3.5 & 23 & 4.1 & 21 \\
\hline May & 11.9 & 23 & 12.3 & 122 & 8.7 & 45 & 8.2 & 103 & 11.9 & 59 \\
\hline June & 17.4 & 50 & 17.9 & 109 & 15.2 & 98 & 14.9 & 134 & 16.6 & 95 \\
\hline July & 21.3 & 42 & 20.6 & 60 & 18.0 & 73 & 16.3 & 71 & 19.1 & 80 \\
\hline August & 18.5 & 26 & 16.9 & 51 & 18.4 & 67 & 16.7 & 113 & 18.1 & 69 \\
\hline September & 12.8 & 94 & 12.3 & 25 & 12.5 & 60 & 16.6 & 63 & 12.1 & 60 \\
\hline October & 3.9 & 36 & 6.2 & 97 & 6.0 & 49 & 3.3 & 29 & 5.4 & 39 \\
\hline Season & 13.5 & 283 & 12.9 & 470 & 11.7 & 413 & 11.4 & 535 & 12.5 & 422 \\
\hline
\end{tabular}


Table 15: Soil physical properties for each plot type in the study area

\begin{tabular}{|c|c|c|c|c|c|c|}
\hline Plot & $\begin{array}{c}\text { Sample } \\
\text { depth }\end{array}$ & $\begin{array}{c}\text { Sand } \\
\%\end{array}$ & $\begin{array}{c}\text { Silt } \\
\%\end{array}$ & $\begin{array}{c}\text { Clay } \\
\%\end{array}$ & $\begin{array}{c}\text { USDA } \\
\text { Texture } \\
\text { Class }\end{array}$ & $\begin{array}{c}\text { Stones } \\
\%\end{array}$ \\
\hline \multirow{4}{*}{ Plot 1: control-grazed } & $0-1$ & 89 & 5 & 6 & Sand & 37.7 \\
\hline & $1-2$ & 93 & 5 & 2 & Sand & 44.0 \\
\hline & $2-3$ & 93 & 5 & 2 & Sand & 41.0 \\
\hline & $3-4$ & 94 & 4 & 2 & Sand & 38.8 \\
\hline \multirow{4}{*}{ Plot 2: split-hayed } & $0-1$ & 83 & 11 & 6 & $\begin{array}{l}\text { Loamy } \\
\text { Sand }\end{array}$ & 27.4 \\
\hline & $1-2$ & 91 & 7 & 2 & Sand & 41.6 \\
\hline & $2-3$ & 93 & 5 & 2 & Sand & 43.1 \\
\hline & $3-4$ & 93 & 5 & 2 & Sand & 36.6 \\
\hline \multirow{4}{*}{ Plot 3: full-grazed } & $0-1$ & 83 & 9 & 8 & $\begin{array}{c}\text { Loamy } \\
\text { Sand }\end{array}$ & 29.0 \\
\hline & $1-2$ & 61 & 36 & 3 & $\begin{array}{c}\text { Loamy } \\
\text { Sand }\end{array}$ & 50.9 \\
\hline & $2-3$ & 92 & 6 & 2 & Sand & 44.2 \\
\hline & $3-4$ & 93 & 5 & 2 & Sand & 41.7 \\
\hline \multirow{4}{*}{ Plot 4: control-hayed } & $0-1$ & 79 & 11 & 10 & $\begin{array}{c}\text { Loamy } \\
\text { Sand }\end{array}$ & 40.2 \\
\hline & $1-2$ & 89 & 7 & 4 & Sand & 52.5 \\
\hline & $2-3$ & 92 & 6 & 2 & Sand & 46.4 \\
\hline & $3-4$ & 93 & 5 & 2 & Sand & 42.4 \\
\hline \multirow{4}{*}{ Plot 5: full-hayed } & $0-1$ & 81 & 11 & 8 & $\begin{array}{c}\text { Loamy } \\
\text { Sand }\end{array}$ & 39.6 \\
\hline & $1-2$ & 89 & 7 & 4 & Sand & 50.4 \\
\hline & $2-3$ & 94 & 4 & 2 & Sand & 43.5 \\
\hline & $3-4$ & 93 & 5 & 2 & Sand & 42.6 \\
\hline \multirow{4}{*}{ Plot 6: split-grazed } & $0-1$ & 81 & 9 & 10 & $\begin{array}{c}\text { Loamy } \\
\text { Sand }\end{array}$ & 35.9 \\
\hline & $1-2$ & 89 & 7 & 4 & Sand & 43.2 \\
\hline & $2-3$ & 93 & 5 & 2 & Sand & 45.7 \\
\hline & $3-4$ & 94 & 4 & 2 & Sand & 34.3 \\
\hline \multirow{4}{*}{ Plot 7: control-grazed } & $0-1$ & 81 & 11 & 8 & $\begin{array}{l}\text { Loamy } \\
\text { Sand }\end{array}$ & 32.3 \\
\hline & $1-2$ & 89 & 7 & 4 & Sand & 39.1 \\
\hline & $2-3$ & 93 & 6 & 1 & Sand & 42.5 \\
\hline & $3-4$ & 91 & 7 & 2 & Sand & 43.5 \\
\hline \multirow{3}{*}{ Plot 8: full-hayed } & $0-1$ & 83 & 9 & 8 & $\begin{array}{c}\text { Loamy } \\
\text { Sand }\end{array}$ & 31.8 \\
\hline & $1-2$ & 91 & 5 & 4 & Sand & 36.3 \\
\hline & $2-3$ & 93 & 5 & 2 & Sand & 35.0 \\
\hline
\end{tabular}




\begin{tabular}{|c|c|c|c|c|c|c|}
\hline & $3-4$ & 93 & 5 & 2 & Sand & 39.4 \\
\hline \multirow{4}{*}{ Plot 9: split-grazed } & $0-1$ & 85 & 10 & 5 & $\begin{array}{l}\text { Loamy } \\
\text { Sand }\end{array}$ & 33.3 \\
\hline & $1-2$ & 89 & 8 & 3 & Sand & 39.2 \\
\hline & $2-3$ & 92 & 7 & 1 & Sand & 36.5 \\
\hline & $3-4$ & 93 & 6 & 1 & Sand & 33.8 \\
\hline \multirow{5}{*}{ Plot 10: split-hayed } & $0-1$ & 81 & 12 & 7 & $\begin{array}{l}\text { Loamy } \\
\text { Sand }\end{array}$ & 26.8 \\
\hline & $1-2$ & 89 & 9 & 2 & Sand & 34.0 \\
\hline & $2-3$ & 93 & 6 & 1 & Sand & 35.6 \\
\hline & $3-4$ & 94 & 5 & 1 & Sand & 34.2 \\
\hline & $0-1$ & 81 & 12 & 7 & $\begin{array}{l}\text { Loamy } \\
\text { Sand }\end{array}$ & 19.4 \\
\hline \multirow[t]{3}{*}{ Plot 11: full-grazed } & $1-2$ & 89 & 8 & 3 & Sand & 30.0 \\
\hline & $2-3$ & 93 & 6 & 1 & Sand & 30.0 \\
\hline & $3-4$ & 93 & 6 & 1 & Sand & 26.5 \\
\hline \multirow{4}{*}{$\begin{array}{l}\text { Plot 12: control- } \\
\text { hayed }\end{array}$} & $0-1$ & 81 & 10 & 9 & $\begin{array}{l}\text { Loamy } \\
\text { Sand }\end{array}$ & 22.5 \\
\hline & $1-2$ & 87 & 8 & 5 & $\begin{array}{l}\text { Loamy } \\
\text { Sand }\end{array}$ & 30.8 \\
\hline & $2-3$ & 93 & 6 & 1 & Sand & 24.8 \\
\hline & $3-4$ & 93 & 6 & 1 & Sand & 19.4 \\
\hline
\end{tabular}




\section{Appendix-B (Soil water)}

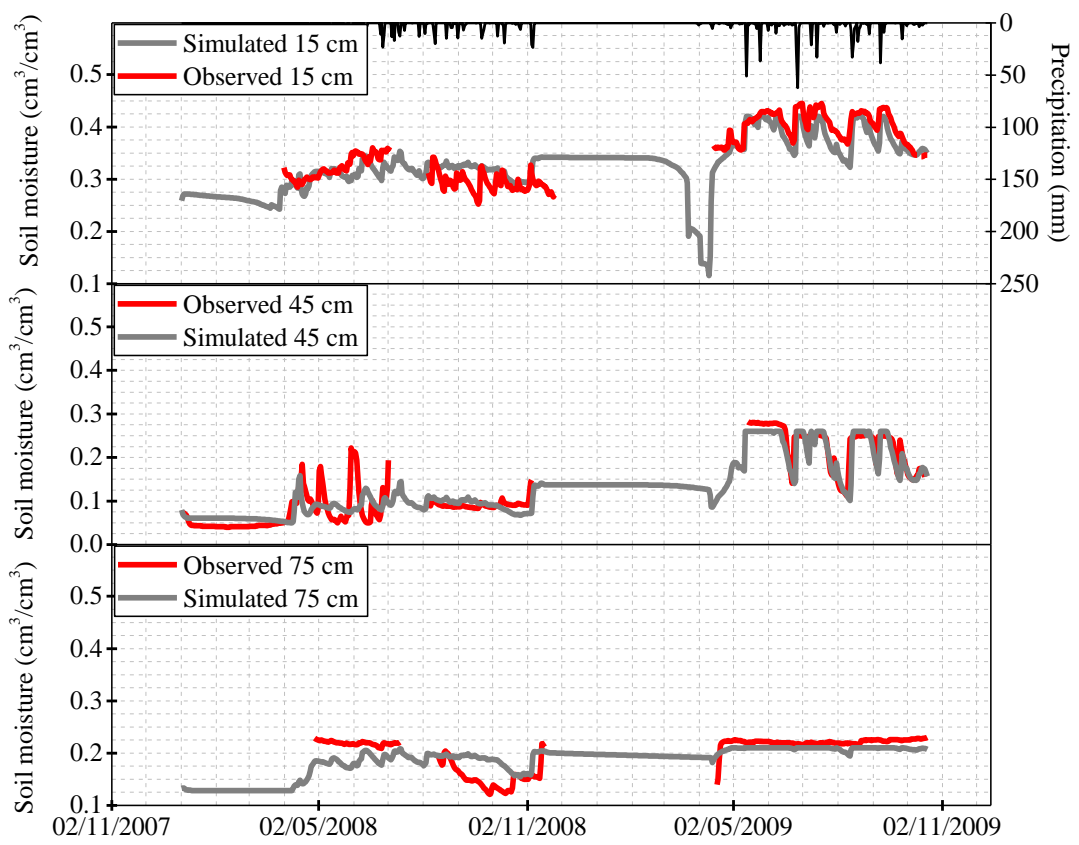

Figure 31: Observed v/s simulated soil moisture contents at depths 15, 45 and $75 \mathrm{~cm}$ using the VGM parameters derived from inverse optimization for SS-1

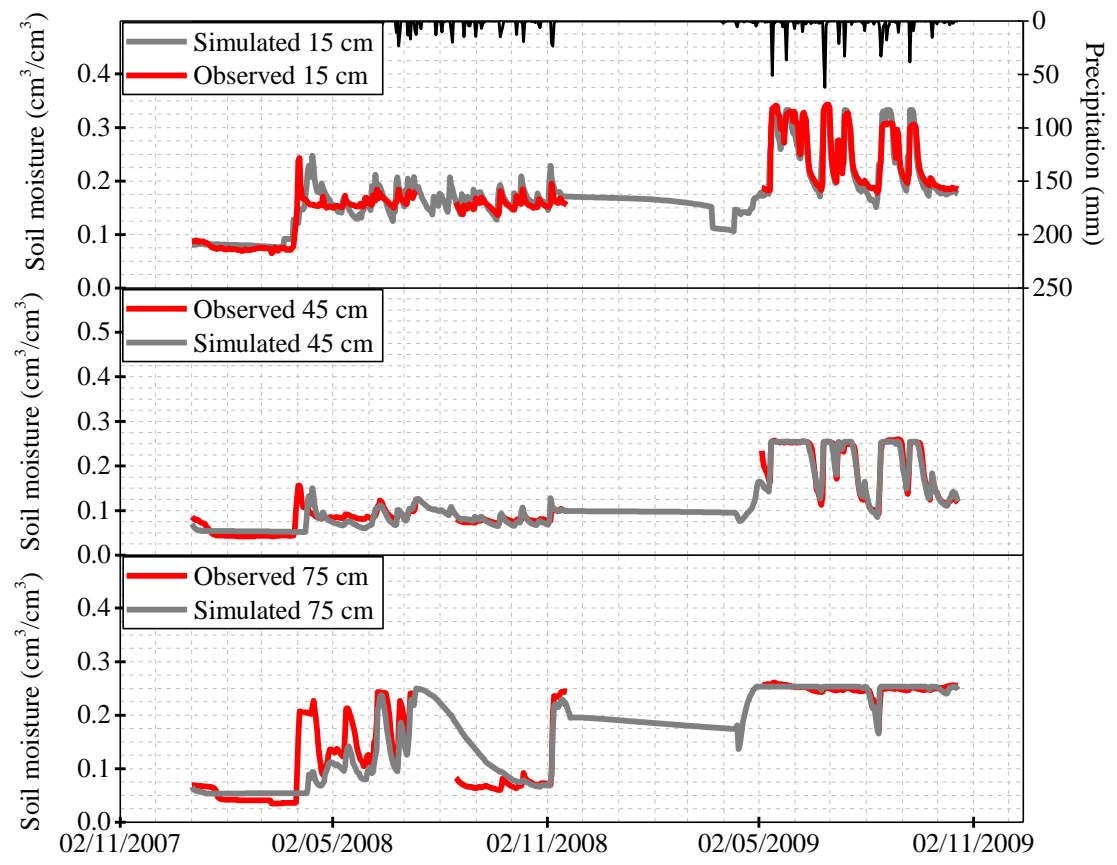

Figure 32: Observed v/s simulated soil moisture contents at depths 15, 45 and $75 \mathrm{~cm}$ using the VGM parameters derived from inverse optimization for SS-2 


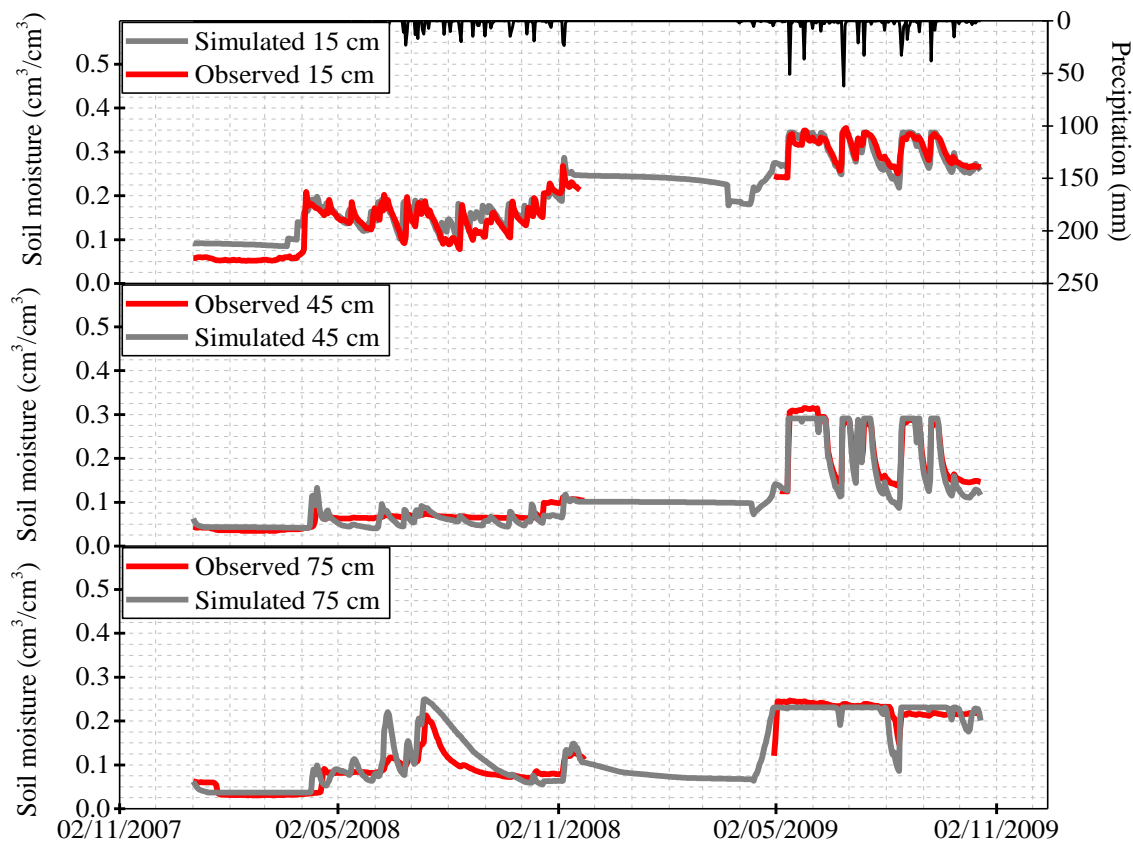

Figure 33: Observed v/s simulated soil moisture contents at depths 15, 45 and $75 \mathrm{~cm}$ using the VGM parameters derived from inverse optimization for SS-4

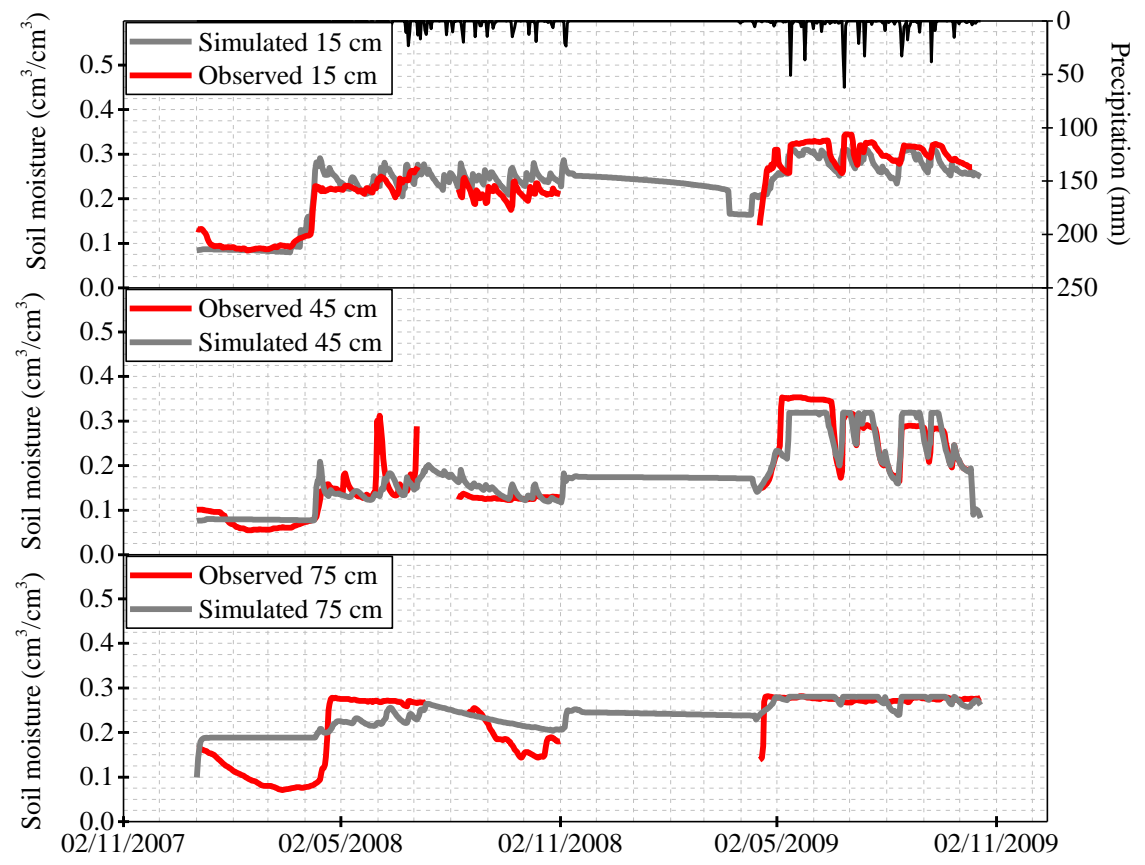

Figure 34: Observed v/s simulated soil moisture contents at depths 15, 45 and $75 \mathrm{~cm}$ using the VGM parameters derived from inverse optimization for SS-5 


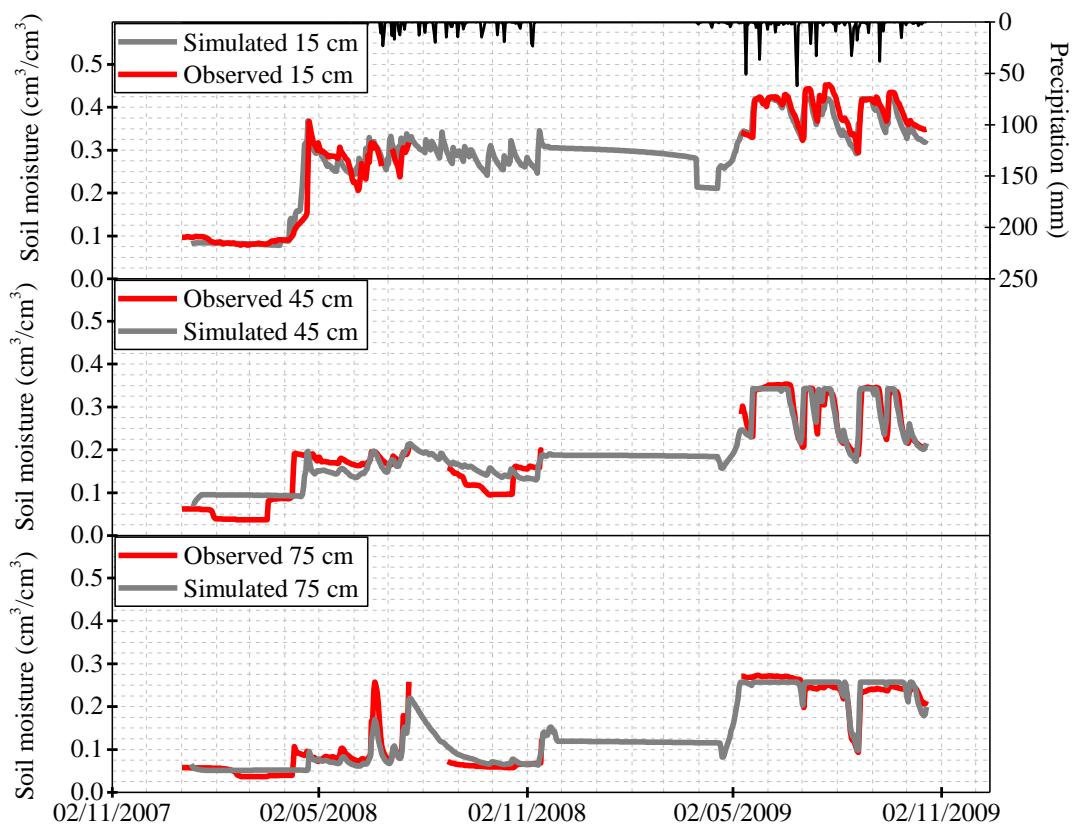

Figure 35: Observed v/s simulated soil moisture contents at depths 15, 45 and $75 \mathrm{~cm}$ using the VGM parameters derived from inverse optimization for SS-6

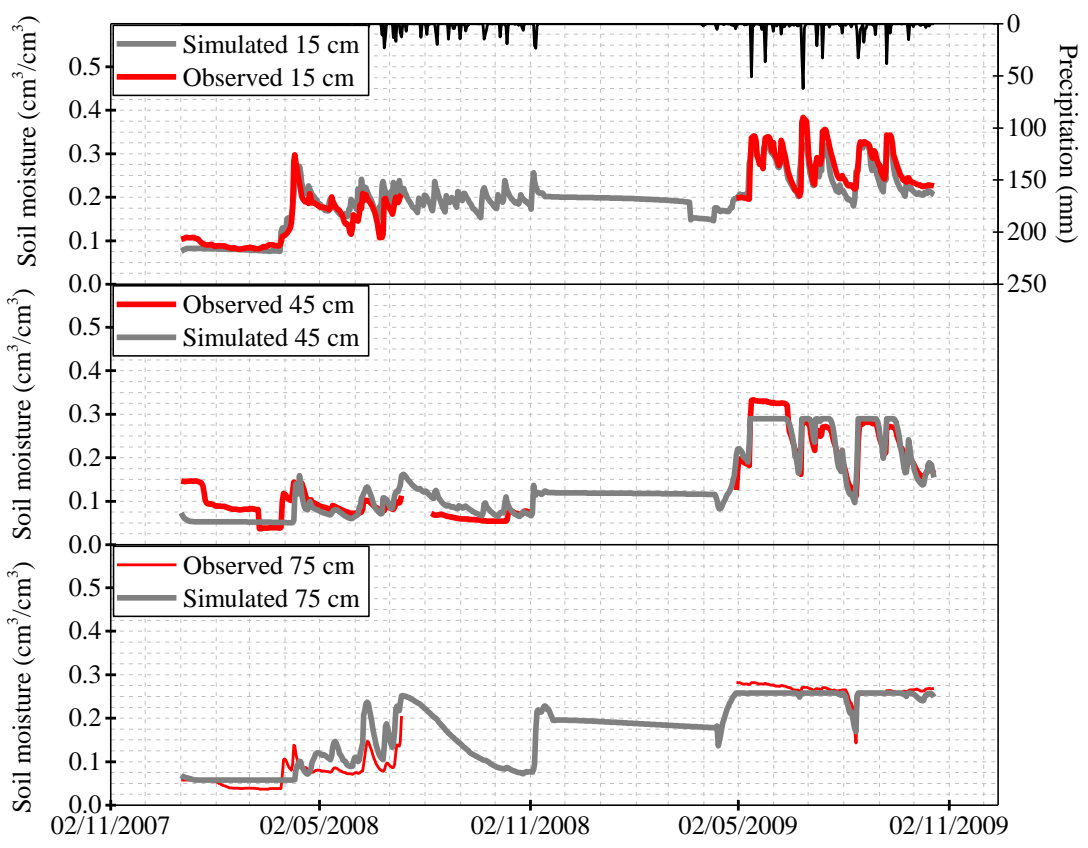

Figure 36: Observed v/s simulated soil moisture contents 15, 45 and $75 \mathrm{~cm}$ using the VGM parameters derived from inverse optimization for SS-7 


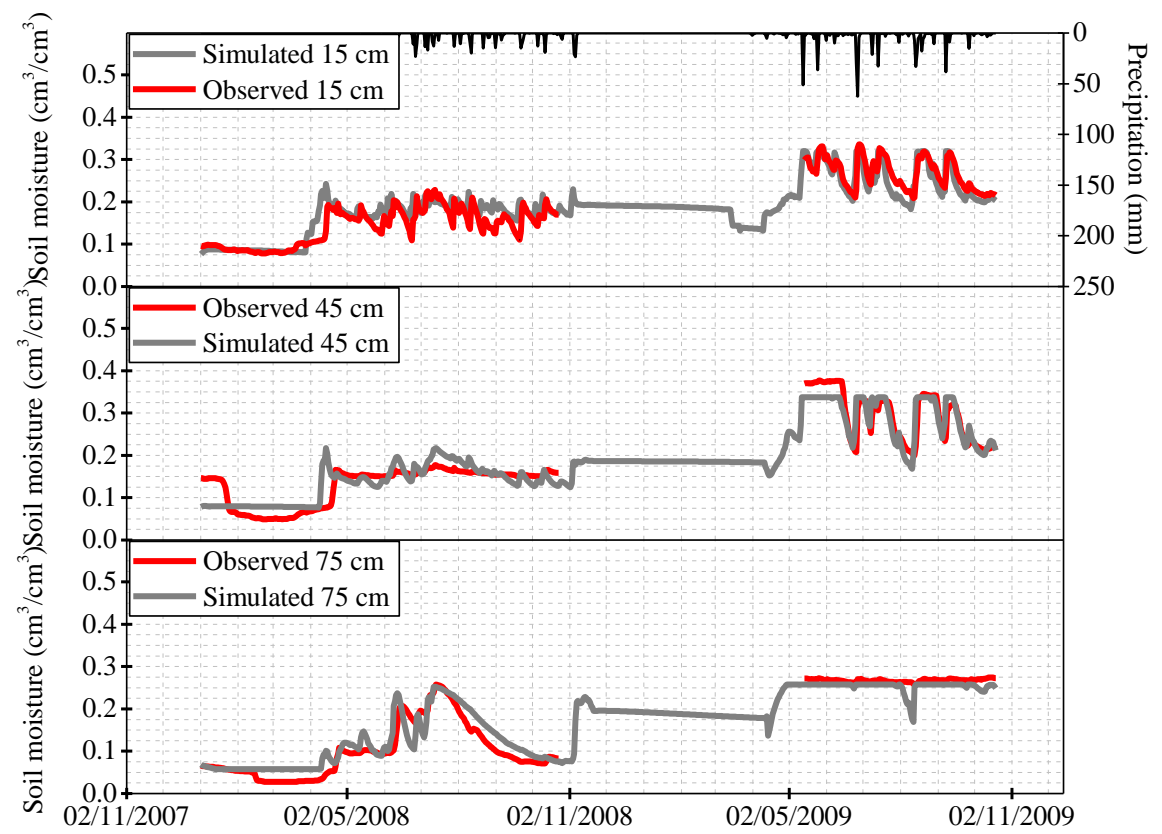

Figure 37: Observed v/s simulated soil moisture contents at depths 15, 45 and $75 \mathrm{~cm}$ using the VGM parameters derived from inverse optimization for SS-8 


\section{Appendix-C (Nitrate leaching)}

Kriging

$\mathrm{N}$

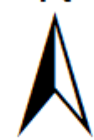

Nitrate leaching (kg/ha)
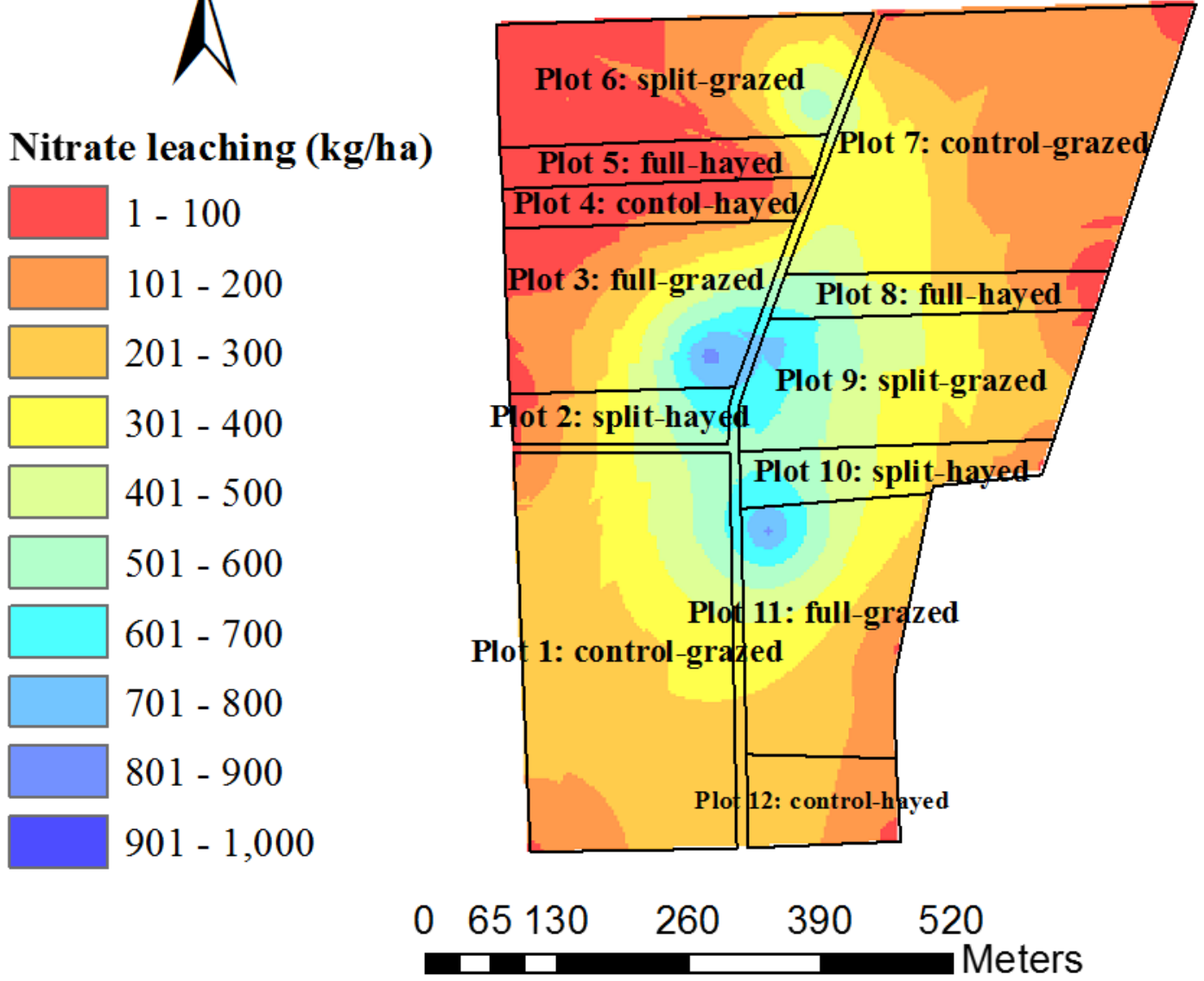

Figure 38: Nitrate leaching fluxes across the study area regionalised using Kriging (average leaching rate: $274 \mathrm{~kg} / \mathrm{ha} /$ year) 


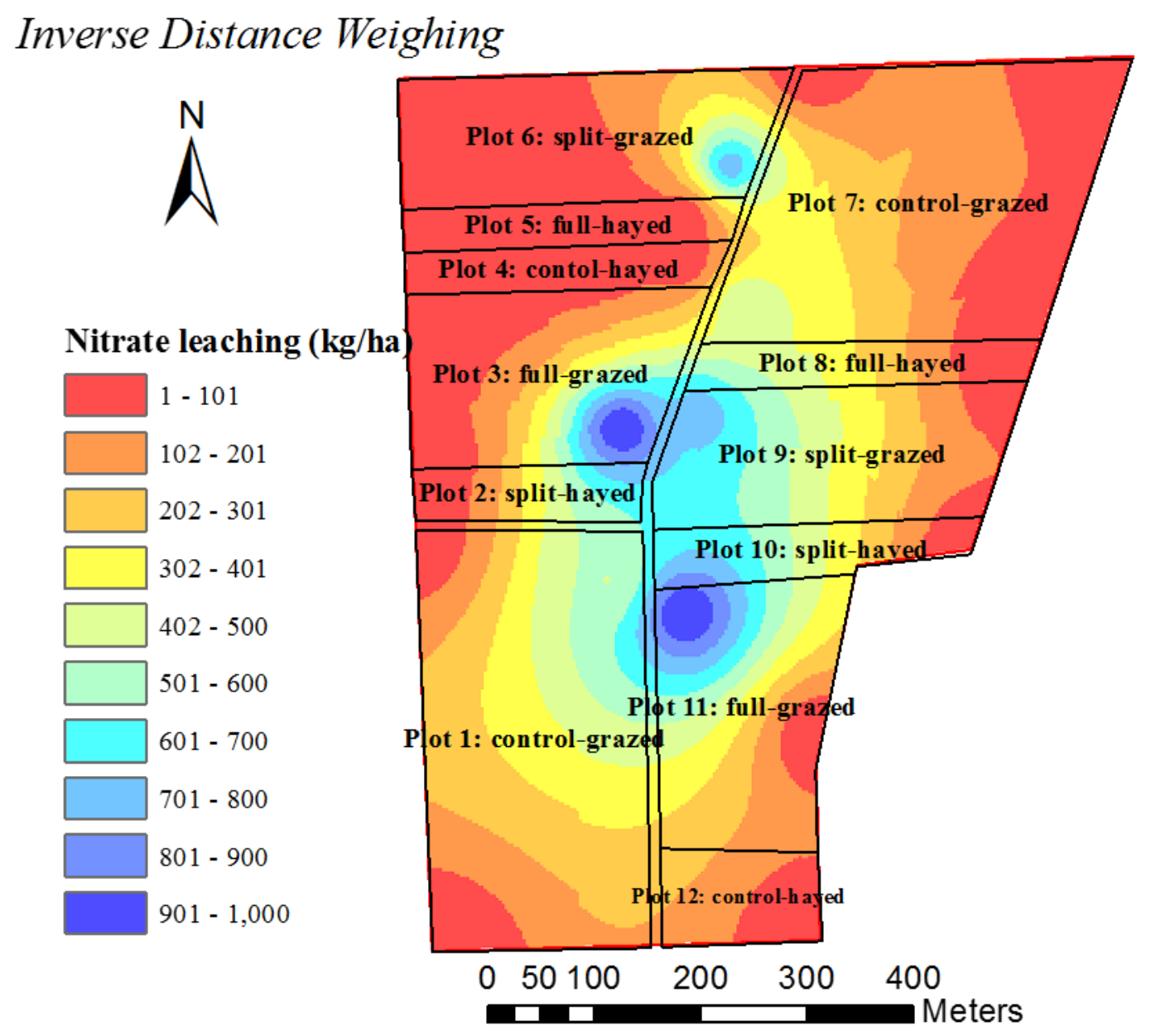

Figure 39: Nitrate leaching fluxes across the study area regionalised using Inverse Distance Weighing (IDW) (average leaching rate: $264 \mathrm{~kg} / \mathrm{ha} /$ year) 


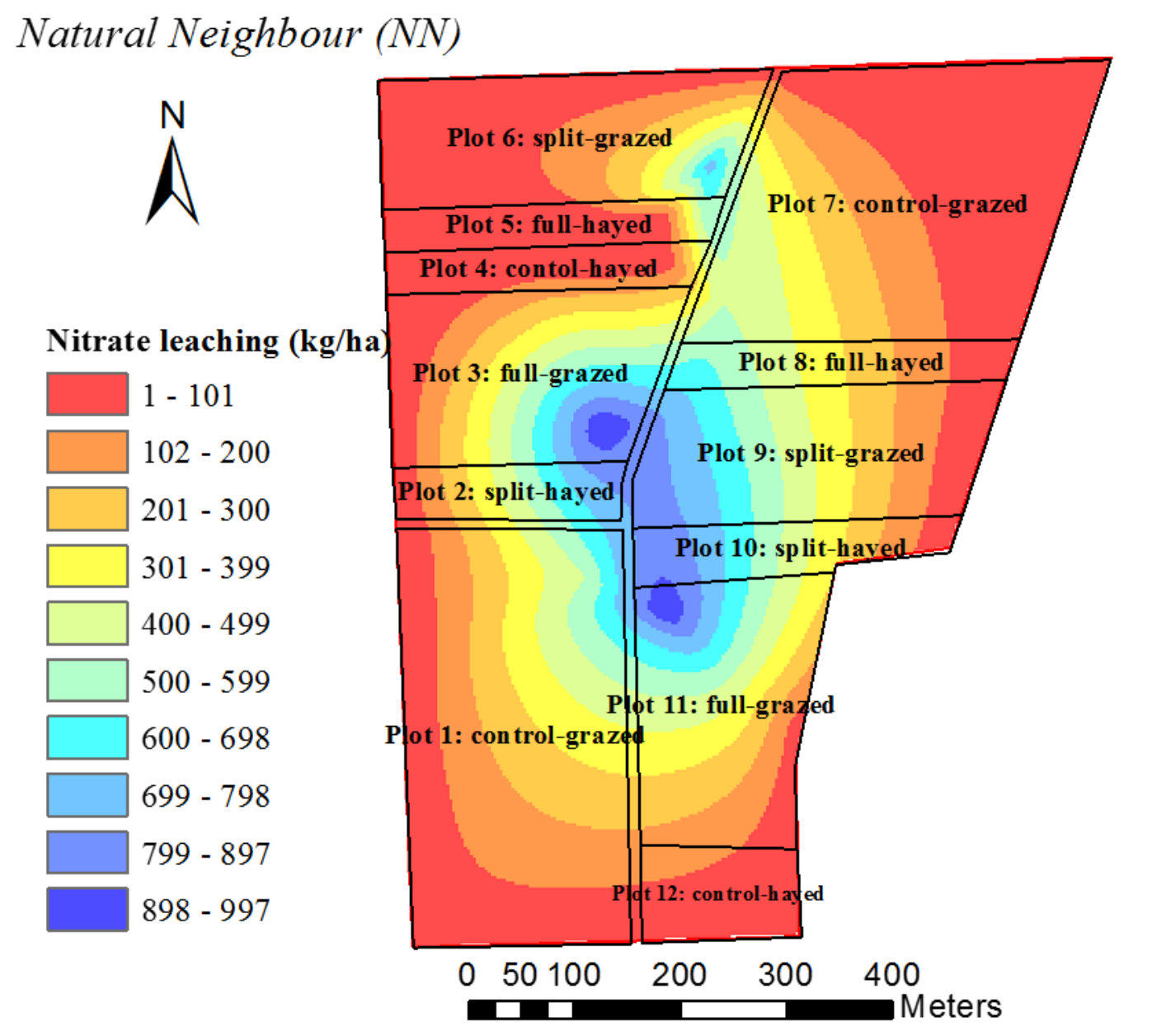

Figure 40: Nitrate leaching fluxes across the study area regionalised using Natural Neighbor interpolation (average leaching rate: $259 \mathrm{~kg} / \mathrm{ha} /$ year) 